
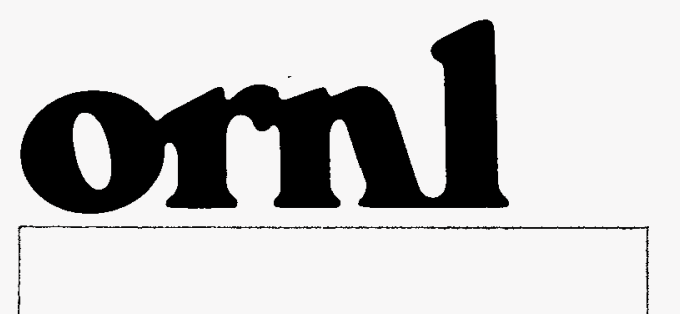

OAK RIDGE NATIONAL LABORATORY

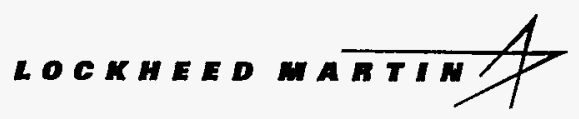

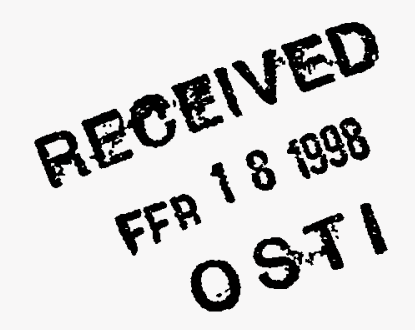

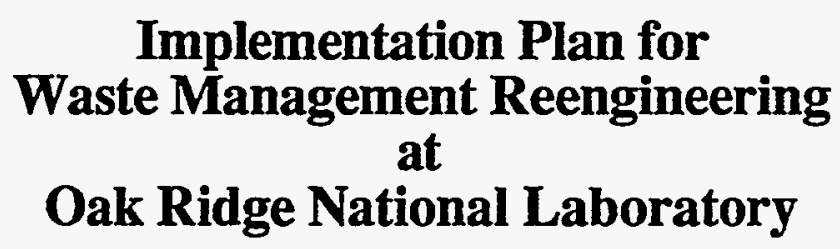

J. B. Berry

October 1997

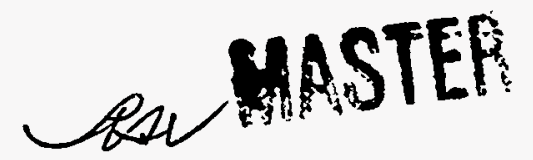

DIBTRIBUTION OF THIS DOCUAENT IS UNLMITED 
This report has been reproduced directly from the best avallable copy.

Available to DOE and DOE contractors from the Office of Scientific and Technical Information, P.O. Box 62, Oak Ridge, TN 37831; prices available from (615) 576-8401. FTS 626-8401.

Available to the public from the National Technical Information Service, U.S. Department of Commerce, 5285 Port Royal Rd., Springfield, VA 22161.

This report was prepared as an account of work sponsored by an agency of the United States Government. Neither the United States Government nor any agency thereof, nor any of their employees, makes any warranty, express or implied, or assumes any logal liability or responsibility for the accuracy, completeness, or usefulness of any information, apparatus, product, or process disclosed, or represents that its use would not infringe privately owned rights. Reference herein to any specific commercial product, process, or service by trade name, trademark, manufecturer, or otherwise, does not necessarily constitute or imply its endorsement, recommendation, or favoring by the United States Government or any agency thereof. The views and opinions of authors expressed herein do not nocessarily state or reflect those of the United States Government or any agency thereof. 


\section{DISCLAIMER}

Portions of this document may be illegible electronic image products. Images are produced from the best available original document. 


\title{
Implementation Plan for Waste Management Reengineering at Oak Ridge National Laboratory
}

\author{
J. B. Berry
}

October 1997

\author{
Prepared by \\ Oak Ridge National Laboratory \\ managed by \\ Lockheed Martin Energy Research Corp. \\ for the \\ U.S. Department of Energy \\ under contract DE-AC05-96OR22464
}


8 


\section{TABLE OF CONTENTS}

EXECUTIVE SUMMARY $\ldots \ldots \ldots \ldots \ldots \ldots \ldots \ldots \ldots \ldots \ldots \ldots \ldots \ldots \ldots \ldots \ldots \ldots \ldots \ldots$

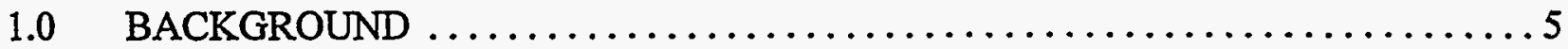

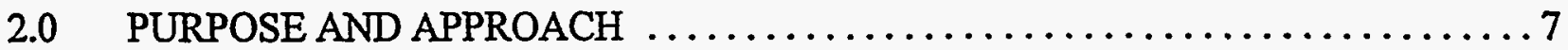

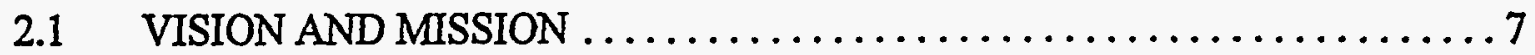

2.2 ANALYSIS AND PLAN DEVELOPMENT $\ldots \ldots \ldots \ldots \ldots \ldots \ldots \ldots . . \ldots$

2.3 WASTE MANAGEMENT IMPLEMENTATION PLAN EXECUTION $\ldots \ldots 10$

3.0 STRATEGY AND IMPLEMENTATION PLAN OVERVIEW $\ldots \ldots \ldots \ldots \ldots \ldots \ldots$

3.1 BEST BUSINESS PRACTICES SUMMARY $\ldots \ldots \ldots \ldots \ldots \ldots \ldots \ldots$

3.2 PROCESS REENGINEERING SUMMARY $\ldots \ldots \ldots \ldots \ldots \ldots \ldots \ldots$

3.3 ADVANCED INFORMATION MANAGEMENT SYSTEMS SUMMARY . . 13

4.0 IMPLEMENTATION OF BEST BUSINESS PRACTICES $\ldots \ldots \ldots \ldots \ldots \ldots \ldots$

4.1 BUSINESS STRATEGY AND APPROACH $\ldots \ldots \ldots \ldots \ldots \ldots \ldots \ldots$

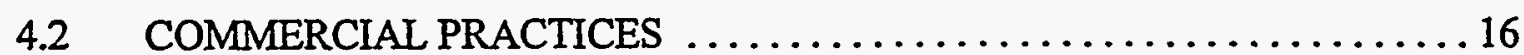

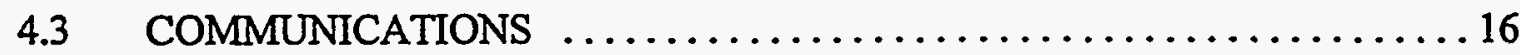

5.0 IMPLEMENTATION OF PROCESS REENGINEERING $\ldots \ldots \ldots \ldots \ldots \ldots \ldots . \ldots 17$

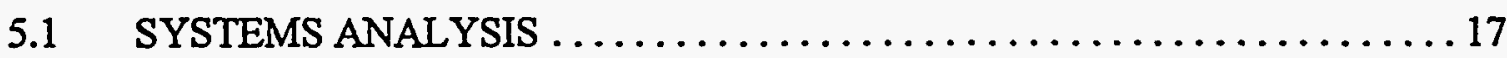

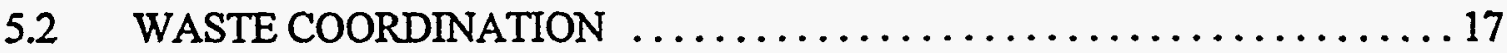

5.3 SOLID LOW-LEVEL WASTE PROCESS $\ldots \ldots \ldots \ldots \ldots \ldots \ldots \ldots \ldots$

5.4 PROCESS WASTE TREATMENT PLANT $\ldots \ldots \ldots \ldots \ldots \ldots \ldots \ldots$

5.5 REQUIREMENTS EVALUATION AND ELIMINATION $\ldots \ldots \ldots \ldots \ldots .20$

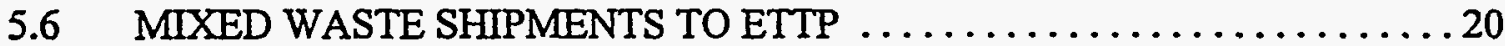

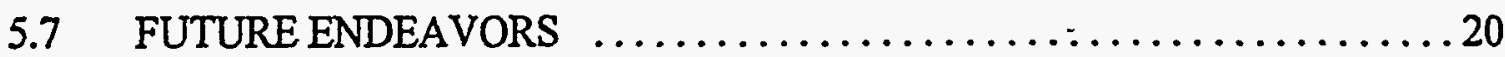

6.0 IMPLEMENTATION OF INFORMATION MANAGEMENT SYSTEMS $\ldots \ldots \ldots 21$

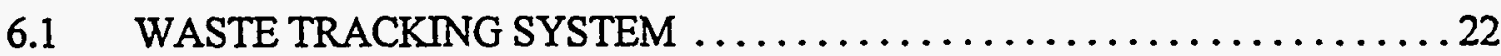

6.2 WASTE INFORMATION MANAGEMENT SYSTEM $\ldots \ldots \ldots \ldots \ldots 22$

7.0 WASTE MANAGEMENT REENGINEERING IMPLEMENTATION BENEFITS $\ldots 23$

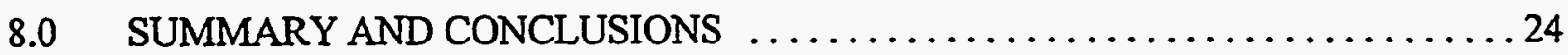

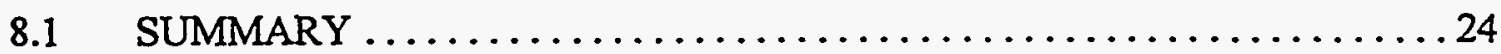

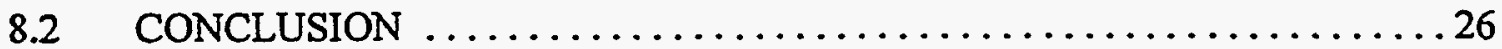




\section{LIST OF TABLES, FIGURES, AND APPENDICES}

\section{TABLES}

Table 1. Key implementation milestones and cost-effectiveness gains . . . . . . . . . . . . 4 Table 2. WMRE recommendations implemented by the implementation work breakdown

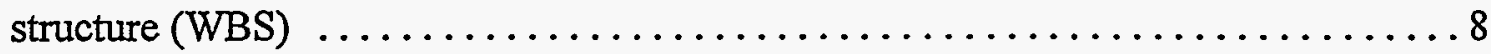

Table 3. Summary of WMRE implementation work breakdown structure, overhead funding,

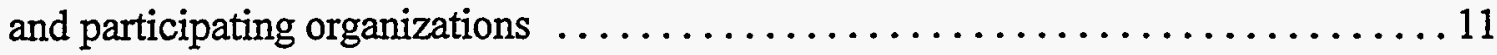

Table 4. Best business practices implementation strategy $\ldots \ldots \ldots \ldots \ldots \ldots \ldots \ldots \ldots \ldots \ldots \ldots \ldots \ldots$

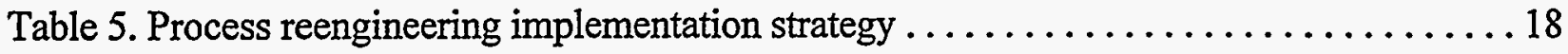

Table 6. Advanced information management systems implementation strategy . . . . . . . 21

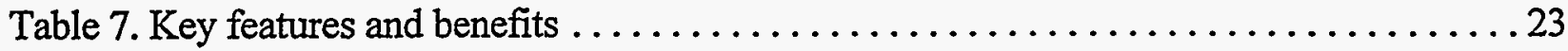

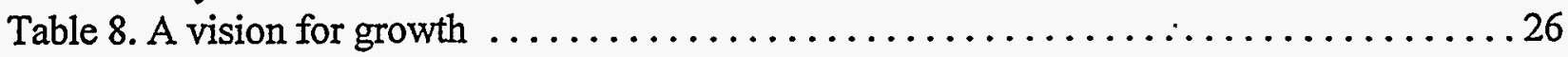

\section{FIGURES}

Fig. 1. Systematic approach to waste management reengineering $\ldots \ldots \ldots \ldots \ldots \ldots \ldots$

Fig. 2. WM reengineering uses WBS to answer questions $\ldots \ldots \ldots \ldots \ldots \ldots \ldots \ldots \ldots \ldots$

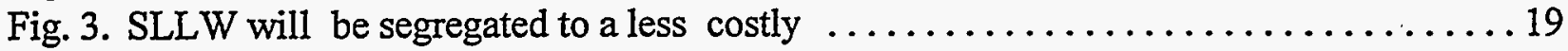

\section{APPENDICES}

Appendix A. Waste Management Reengineering Core Team Recommendations ....... A-1

Appendix B. Waste Management Reengineering Work Breakdown Structure $\ldots \ldots \ldots \ldots$ B-1

Appendix C. Cost by Work Breakdown Structure $\ldots \ldots \ldots \ldots \ldots \ldots \ldots \ldots \ldots \ldots$ C-1

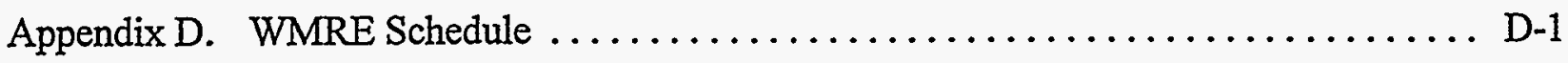




\section{LIST OF ACRONYMS AND ABBREVIATIONS}

\begin{tabular}{|c|c|}
\hline $\mathrm{ADS}$ & activity data sheet \\
\hline AVID & Accelerated Vendor Inventory Delivery \\
\hline BUS & Between Use Storage \\
\hline $\mathrm{CBD}$ & Commerce Business Daily \\
\hline CERCLA & $\begin{array}{l}\text { Comprehensive Environmental Response, Compensation, and } \\
\text { Liability Act of } 1980\end{array}$ \\
\hline $\mathrm{COO}$ & conduct of operations \\
\hline COTS & commercially available off-the-shelf software \\
\hline DAW & dry active waste \\
\hline DOE & Department of Energy \\
\hline DOE-ER & DOE-Energy Research \\
\hline DOE-OR & DOE-Oak Ridge \\
\hline DOT & Department of Transportation \\
\hline DQO & data quality objective \\
\hline ETX & Electrochemical Ion-Exchange \\
\hline EM & Environmental Management \\
\hline EM\&EF & Environmental Management and Enrichment Facilities \\
\hline ER & Energy Research \\
\hline ETTP & East Tennessee Technology Park \\
\hline FWP & field work proposal \\
\hline FY & fiscal year \\
\hline GAC & granulated activated carbon \\
\hline GES & Generator Entry System \\
\hline GIG & Generator Interface Group \\
\hline HMIS & Hazardous Material Information System \\
\hline HP & Health Physics \\
\hline IWMF & Interim Waste Management Facility \\
\hline LGWO & Liquid Gaseous Waste Operations \\
\hline LLLW & liquid low-level waste \\
\hline LM & Lockheed Martin \\
\hline LMER & Lockheed Martin Energy Research Corp. \\
\hline LMES & Lockheed Martin Energy Systems, Inc. \\
\hline $\mathrm{M}$ & million \\
\hline M\&I & Management and Integration \\
\hline MLLW & mixed low-level waste \\
\hline MOUs & Memorandum of Understandings \\
\hline MVST & Melton Valley storage tank \\
\hline NG & newly generated \\
\hline NPDES & National Pollution Discharge Elimination System \\
\hline NRWTP & Non-Radiological Wastewater Treatment Plant \\
\hline
\end{tabular}


A. W. Buttram, and

V. C. Moore.

Also, the efforts of external support staff made the timely completion of the document possible.

L. D. Byers, EET TN Corp.,

S. N. Duncan, PrSM,

J. M. Ray, PrSM, and

C. A. Stevens, Science Applications International Corporation. 


\section{EXECUTIVE SUMMARY}

An intensive reengineering evaluation of the Oak Ridge National Laboratory (ORNL) waste management program was conducted from February to July 1997 resulting in the following vision for ORNL waste management:

ORNL Waste Management will become an integrated Waste Management/Generator function that:

- Treats ORNL as a single generator for expert-based waste characterization and certification purposes;

- Recognizes Generators, Department of Energy (DOE), and the Management and Integration (M\&I) contractor as equally important customers;

- Focuses on pollution prevention followed by waste generation, collection, treatment, storage, and disposal operations that reflect more cost-effective commercial approaches; and

- Incorporates new technology and outsourcing of services where appropriate to provide the lowest cost solutions. ${ }^{1}$

A cross-functional Core Team recommended 15 cost-effectiveness improvements that are expected to reduce the fiscal year (FY) 1996 ORNL waste management costs of $\$ 75 \mathrm{M}$ by $\$ 10-\$ 15 \mathrm{M}$ annually. These efficiency improvements will be realized by both Research and Waste Management Organizations.

Proceeding with implementation of Waste Management Reengineering (WMRE) was approved by the ORNL Executive Committee on July 28, 1997, and ORNL's Reengineering Steering Committee, led by J. O. Stiegler. T. E. Myrick, Director, Office of Environmental Management Programs, was commissioned to oversee implementation, and appointed J. B. Berry to manage implementation of the WMRE Program. Using the Core Team's vision and 15 recommendations as the basis of the implementation strategy, the following two-element mission was developed:

- Enhance the competitive position of ORNL researchers and the success of Environmental Management (EM) by reducing costs of waste management. This element will be accomplished by providing cost-effective, safe, and compliant waste management services for newly generated waste streams and reducing the time spent by research staff on meeting waste management requirements.

- Position ORNL to provide legacy waste management services to the M\&I contractor. This element will be accomplished by helping researchers exercise their responsibility to segregate and manage waste. Improved waste segregation will reduce waste types and volumes thereby freeing waste management staff to focus on activities that reduce costs of ORNL waste management. 
This mission will be achieved through an implementation approach that benefits both DOE-EM and DOE-Energy Research (ER) as well as ORNL and the M\&I contractor. Support from these organizations to implement waste management reengineering can be gained if answers to the following questions are clearly understood:

1. Why will ORNL staff have the incentive to make changes and implement reengineering?

2. What waste stream handling processes will be reengineered?

3. How will waste management reengineering reduce costs?

Development of a reengineering work breakdown structure (WBS) provided a framework to answer these questions. The framework design includes three major WBS elements that form the structure for building the implementation strategy:

- Best Business Practices

- Process Reengineering

- Advanced Information Management Systems

Best Business Practices establish the rationale for reengineering including a business strategy that uses performance-based incentives. Such incentives will provide clear rewards for behaviors that reduce the cost of managing waste. The success of the reengineering effort depends on changes in the work practices of waste generators, including research, support, and construction organizations and changes in the work practices of the Waste Management and Remedial Action Division (WMRAD). ORNL senior management is committed to modify business practices, as evidenced by establishment of the OEMP, by advocating cost-effective changes with $\mathrm{DOE}$, the M\&I contractor, and/or regulators.

Process Reengineering establishes what must be reengineered including processes and the related waste streams. A detailed systems analysis will build upon the brief assessment conducted earlier ${ }^{1}$ and will further define activities that are used to manage waste. Current life-cycle costs will be better defined and opportunities to reduce life-cycle costs will be identified so activities can be streamlined. Streamlined processes will result in efficiency improvements that will free up the waste handling infrastructure. WMRAD will use this excess capability to more effectively manage newly generated waste and to cost-effectively process legacy waste for the M\&I contractor.

Process Reengineering also includes specific tasks that will reduce costs: Reengineering Waste Coordination, Reengineering the Solid Low-Level Waste (SLLW) Process, and Reengineering the Process Waste Treatment Plant (PWTP). Improved waste coordination and interaction with researchers and generators will reduce researcher time spent on waste management activities. SLLW process improvements include improved segregation of SLLW and industrial/sanitary waste to significantly reduce newly generated dry active waste (DAW) volumes (up to $25 \%$ ). The function of the PWTP will be replaced with more cost-effective treatment methods. 
Advanced Information Management Systems will establish a streamlined waste characterization, certification, and verification process. The success of these projects will be used to understand how well the incentive structure functions to change behavior and to measure process performance improvements.

A multidisciplinary implementation team of ORNL staff, support contractors, and consultants have prepared the following Implementation Plan. The implementation schedule contains milestones that will result in significant cost savings (see Table 1). Cost-effectiveness gains of $\$ 9 \mathrm{M}$ are expected to result from major FY 1998 reengineering activities. Cost improvements that should occur during each fiscal year starting with FY 1998 will be predicted and tracked using performance metrics, which will be implemented by January 1998. Based on the results of performance tracking, the reengineering initiatives will be continuously improved. If actual decreases in the cost of managing waste are not consistent with projections for FY 1998, reengineering initiatives will be reevaluated.

The WMRE Core Team now serves as the primary steering committee to offer advice regarding implementation. A Customer Advisory Panel was chartered on September 26, 1997, to provide an additional forum for senior ORNL managers who represent primary divisions or organizations involved in waste generation or management. The panel will be a key mechanism to initiate and instill cultural and operational change to more cost-effective waste management practices within ORNL line organizations.

Improving the cost-effectiveness of waste management is important to ORNL's future. If consistent and thoughtful action is not taken, researchers will continue to be handicapped by high waste management costs and the M\&I contractor may determine that ORNL services are not cost-effective. Conversely, implementing more cost-effective approaches to ORNL waste management can benefit DOE-ER and DOE-EM programs and ORNL. A successful growth strategy will result in researchers being able to apply more of their funding to research and ORNL being able to reduce unit costs for managing both newly generated and legacy waste. In time, excess ORNL capability to manage waste would be used to cost-effectively treat legacy waste for the M\&I contractor. Cost-effective. waste management experts using streamlined waste management processes will allow this vision for growth to become a reality. 
Table 1. Key implementation milestones and cost-effectiveness gains

\begin{tabular}{|c|c|c|c|}
\hline 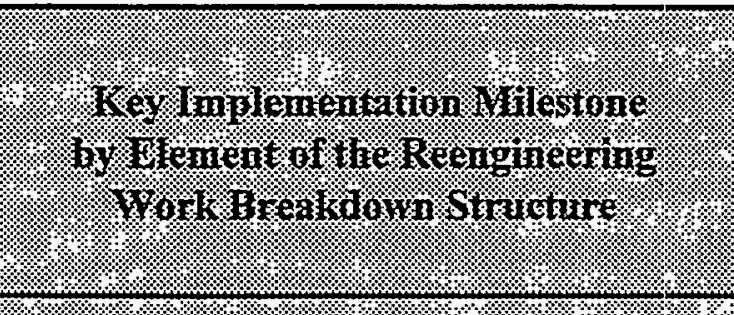 & Re: & 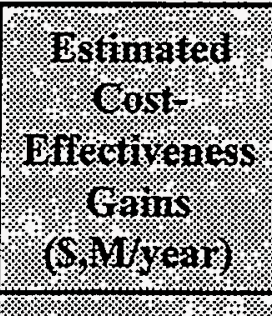 & I \\
\hline 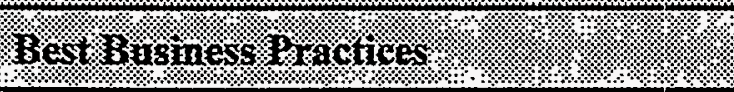 & (1., & (1) & 18 \\
\hline $\begin{array}{l}\text { Implement incentives: } \\
\text { 1. For researchers to reduce time spent } \\
\text { on waste management. } \\
\text { 2. For researchers and generators to } \\
\text { reduce and segregate waste at its } \\
\text { source. } \\
\text { 3. For WMRAD to become more cost- } \\
\text { effective and accept performance risk } \\
\text { (e.g., streamline operations, ship } \\
\text { waste off-site). }\end{array}$ & $\begin{array}{l}\text { ORNL } \\
\text { Overhead } \\
\text { (OH) } \\
\text { Generators } \\
\text { Generators } \\
\text { WMRAD }\end{array}$ & 3 & January 1998 \\
\hline Process Reengineerng & $8 \times$ & 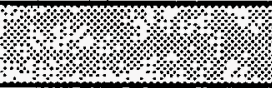 & \%:। \\
\hline $\begin{array}{l}\text { Link waste generation and disposal end- } \\
\text { points for solid waste processes. }\end{array}$ & ORNL OH & 1 & April 1998 \\
\hline $\begin{array}{l}\text { Reduce the source of DAWs within } \\
\text { SLLW: } \\
\text { - } 15 \% \text { of current generation } \\
\text { - } 25 \% \text { of current generation }\end{array}$ & $\begin{array}{l}\text { ORNL OH, } \\
\text { WMRAD, and } \\
\text { Generators }\end{array}$ & 1 & $\begin{array}{l}\text { April } 1998 \\
\text { September } 1998\end{array}$ \\
\hline $\begin{array}{l}\text { Implement improved no-rad added } \\
\text { program. }\end{array}$ & $\begin{array}{l}\text { WMRAD } \\
\text { Generators }\end{array}$ & 1 & April 1998 \\
\hline Determine PWTP replacement approach. & $\begin{array}{l}\text { ORNL OH } \\
\text { WMRAD }\end{array}$ & 2 & December 1997 \\
\hline $\begin{array}{l}\text { Adranced loformation yagagennent } \\
\text { Systems: }\end{array}$ & & & ?.4\%? \\
\hline Improve information collection tools. & ORNL OH & 1 & 1998 \\
\hline
\end{tabular}




\subsection{BACKGROUND}

As Congress reduces federal spending, the Department of Energy (DOE) and its contractors must find innovative, cost-effective approaches to accomplish mission-critical tasks. Oak Ridge National Laboratory (ORNL) management committed to the responsible stewardship of functions critical to the research and development (R\&D) mission with the formation of Lockheed Martin Energy Research Corp. (LMER) and its contract with DOE for operation of ORNL. In keeping with this strategy, ORNL has formed the Office of Environmental Management Programs (OEMP). OEMP provides a single point of contact for each of the major EM programs and fosters the change in culture that is necessary to continue safe and compliant operations with reduced funding.

ORNL waste management (e.g., transportation, storage) is currently sponsored by DOE-EM. DOE-ER sponsors research that generates waste and the related waste generation activities (e.g., waste characterization). DOE Oak Ridge (DOE-OR) and ORNL management recognized that reducing both the Waste Management and Remedial Action Division (WMRAD) and waste. generators' costs would benefit both DOE-EM and DOE-ER programs. Waste management costs must be controlled and reduced if ORNL is to process newly generated waste and increasing volumes of legacy waste with lower budgets. In addition, the cost for ORNL staff to conduct research must be comparable to other institutions that conduct world-class research.

DOE has proposed the return of responsibility (and cost) for management of newly generated waste to the generating DOE programs as a way of providing an incentive for waste minimization and pollution prevention. If implemented as proposed, the management of newly generated ORNL wastes, which is currently funded by the DOE-EM, will become the responsibility of DOE-ER. If funding for waste management is not transferred to wastegenerating DOE programs, there is still a need for incentives to motivate responsible waste generation and management.

In light of these challenges, ORNL management initiated reengineering of both aspects of ORNL waste management performed by: Research Organizations and WMRAD. The reengineering effort was commissioned by ORNL's Reengineering Steering Committee, led by

J. O. Stiegler. T. E. Myrick, OEMP Director, led the evaluation phase of the Waste Management Reengineering (WMRE) Program. The program's objectives were to identify opportunities to improve efficiencies and reduce costs in support of the $R \& D$ mission. The evaluation phase was conducted from February to July 1997. A cross-functional Core Team was established that conducted preliminary evaluations determining eight aspects of the waste management program that warranted special review. The Core Team then commissioned eight, in-depth process teams to address these areas. The process teams, in turn, generated 81 specific recommendations to improve operations. The Core Team then consolidated these into 15 recommendations, which, when implemented, are expected to improve the cost-effectiveness of ORNL waste management by $\$ 10-\$ 15 \mathrm{M}$ annually. These efficiency improvements will be realized by both Research Organizations and WMRAD. 
While their scope was limited to newly generated wastes, the reengineering team observed that successful implementation of their recommendations should enhance LMER's ability to provide service to the new Management and Integration (M\&I) contractor for legacy waste. This would allow the waste management organization to increase its funding base while further reducing costs to ORNL mission organizations.

On July 28, 1997, the ORNL Executive Committee approved proceeding with implementation of WMRE as recommended by the Core Team. The reengineering team's report ${ }^{1}$ was published in August 1997. T. E. Myrick was directed to oversee implementation and J. B. Berry was appointed to manage the implementation phase of the WMRE Program. A WMRE implementation team was formed and developed this Implementation Plan. 


\subsection{PURPOSE AND APPROACH}

\subsection{VISION AND MISSION}

The purpose of this Implementation Plan is to identify the specific actions, costs, and schedules for implementing WMRE. The report on Reengineering of Waste Management at the Oak Ridge National Laboratory and the 15 recommendations of the Core Team form the basis of the implementation strategy. In their report, the Core Team summarizes their vision for ORNL waste management with the following elements.

ORNL Waste Management will become an integrated Waste Management/Generator function that:

- Treats ORNL as a single generator for expert-based waste characterization and certification purposes;

- Recognizes generators, DOE, and the M\&I contractor as equally important customers;

- Focuses on pollution prevention followed by waste generation, collection, treatment, storage, and disposal operations that reflect more cost-effective commercial approaches; and

- Incorporates new technology and outsourcing of services where appropriate to provide the lowest cost solutions. ${ }^{1}$

Using the Core Team vision as a foundation, the following two-element mission was developed by the WMRE implementation team to focus development of this Implementation Plan. WMRE will:

- Enhance the competitive position of ORNL researchers and the success of EM by reducing costs of waste management. This element will be accomplished by providing costeffective, safe, and compliant waste management services for newly generated waste streams and reducing the time spent by research staff on meeting waste management requirements.

- Position ORNL to provide legacy waste management services to the M\&I contractor. This element will be accomplished by helping researchers exercise their responsibility to segregate and manage waste. Improved waste segregation will reduce waste types and volumes thereby freeing waste management staff to focus on activities that reduce costs of ORNL waste management.

This mission will be implemented using WMRE major work breakdown structure (WBS) elements: Best Business Practices, Process Reengineering, and Advanced Information Management Systems (see Table 2). 
Table 2. WMRE recommendations implemented by the implementation work breakdown structure (WBS)

\begin{tabular}{|c|c|c|}
\hline WBS Elentent on Tas & WMRE Core Tearin Reconinengation $/$. & 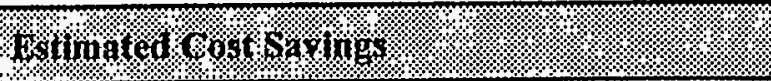 \\
\hline \multicolumn{3}{|c|}{ (2) } \\
\hline $\begin{array}{l}\text { 1.1.1 Business Strategy and } \\
\text { Approach }\end{array}$ & $\begin{array}{l}\text { - Improve Waste Management (WM) operating cost- } \\
\text { effectiveness. }\end{array}$ & - \$3M/year \\
\hline 1.1.2 Commercial Practices & $\begin{array}{l}\text { - Shift paradigm to reflect ORNL as a single generator. } \\
\text { - Establish direct ORNL involvement with disposal } \\
\text { endpoints. } \\
\text { - Improve communications with and accountability of } \\
\text { subcontractors. }\end{array}$ & $\begin{array}{l}\text { - Included in other recommendations } \\
\text { - Included in Systems Analysis savings } \\
\text { - } \$ 50 \mathrm{~K} / \text { year }\end{array}$ \\
\hline 1.1.3 Communications & $\begin{array}{l}\text { - Shift WM customer service orientation to include } \\
\text { DOE-EM, research organizations, and M\&I contractor. }\end{array}$ & - Included in other recommendations \\
\hline \multicolumn{3}{|c|}{ (1) } \\
\hline 1.2.1 Systems Analysis & - Perform systems analysis as the basis for strategic plans. & $\begin{array}{l}\text { - Continuous improvements of waste stream } \\
\text { processes }\end{array}$ \\
\hline $\begin{array}{l}\text { 1.2.2 Waste Coordination } \\
\text { Reengineering }\end{array}$ & $\begin{array}{l}\text { - Eliminate policy mixed waste through effective } \\
\text { implementation of the No-Rad Added Policy. }\end{array}$ & - $\$ 250 \mathrm{~K} /$ year plus $\$ 1.5 \mathrm{M}$ in FY 1998 \\
\hline 1.2.3 SLLW Process Reengineering & $\begin{array}{l}\text { - Modify ORNL's SLLW management process to mimic } \\
\text { the commercial nuclear industry. } \\
\text { - Strengthen and emphasize ORNL pollution prevention } \\
\text { program. }\end{array}$ & $\begin{array}{l}\text { - } \$ 1 \mathrm{M}-\$ 2.6 \mathrm{M} / \text { year } \\
\text { - } \$ 500 \mathrm{~K} / \text { year }\end{array}$ \\
\hline 1.2.4 PWTP Reengineering & - Replace the function of the PWTP. & - $\$ 2 \mathrm{M} /$ year plus LLW decrease \\
\hline $\begin{array}{l}\text { 1.2.5 Requirements Evaluation and } \\
\text { Elimination }\end{array}$ & $\begin{array}{l}\text { - Eliminate excess conservatism in Operations } \\
\text { Requirements Documents. }\end{array}$ & - $\$ 2 \mathrm{M} /$ year \\
\hline in & 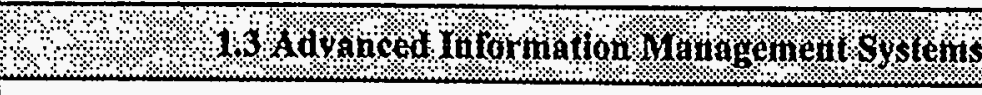 & 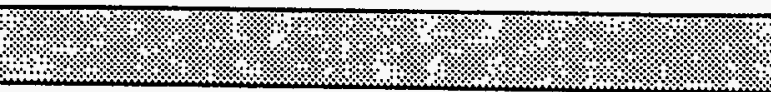 \\
\hline $\begin{array}{l}\text { 1.3.2 Creation of Seamless Waste } \\
\text { Information Management Systems }\end{array}$ & $\begin{array}{l}\text { - Create a single, expert-based ORNL waste } \\
\text { characterization, verification, and certification program } \\
\text { and organization. } \\
\text { - Improve information management tools. }\end{array}$ & $\begin{array}{l}\text { - } \$ 6 \mathrm{M} / \text { year } \\
\text { - } \$ 1.4 \mathrm{M} / \text { year } \\
\end{array}$ \\
\hline
\end{tabular}




\subsection{ANALYSIS AND PLAN DEVELOPMENT}

After analyzing the Reengineering report, the 15 Core Team recommendations, and the 81 process team recommendations, the WMRE implementation team crafted a WBS to provide a framework for implementation. In developmient of the WBS, special care was taken to ensure that the integrity of the reengineering evaluation and recommendations was maintained (see Table 2). ${ }^{1}$ The following two recommendations have been implemented: Re-examine WMRAD organization, and Upgrade Waste Tracking System (see Appendix A). The 81 process team recommendations provide insight regarding reengineering issues and their resolution. Therefore, process team recommendations were also incorporated into the WBS and contributed to development of this Implementation Plan. Appendix A illustrates how these recommendations are incorporated into the WBS.

A systems approach was used to plan implementation of WMRE (see Fig. 1).The WMRE Core Team recommendations provide requirements for WMRE. The WMRE WBS provides a

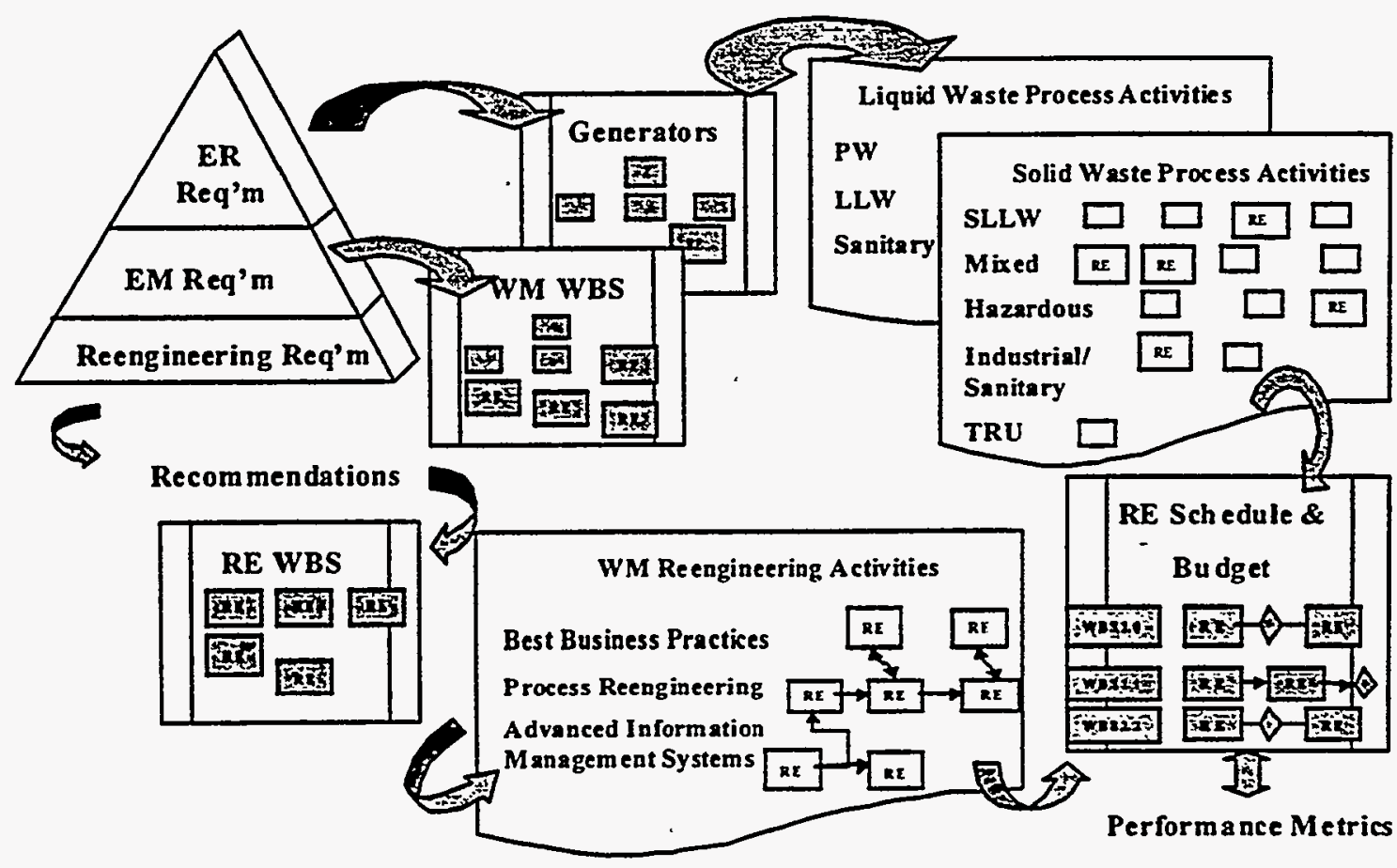

Fig. 1. Systematic approach to waste management reengineering. 
framework to plan implementation of these recommendations. Three major WBS elements were developed: Best Business Practices, Process Reengineering, and Advanced Information Management Systems. Each WBS element is supported by tasks that are in turn supported by subtasks. The implementation team described each subtask and allocated resources to accomplish the scope. Subtask costs and schedules were combined to describe the WBS tasks (see Appendices B and C). Tasks were structured into a logic sequence, with milestones and deliverables, forming a resource-loaded schedule (see Appendix D). This structure establishes a cost baseline and supports prioritization of tasks for funding. The bottom half of Figure 1 shows the above analysis and implementation plan development steps.

The top half of Figure 1 illustrates how ongoing activities will be improved through WMRE. ER requirements must be met by researchers/generators while EM program requirements are implemented by WMRAD. As EM requirements have been implemented, researchers have been required to spend a large portion of their time meeting these requirements to manage wastes. Requirements result in work that can be organized into work breakdown structures for WMRAD and for generators. This work is conducted by a series of activities in a logical sequence for both liquid and solid waste. Process activity diagrams will be developed to describe both generator and WMRAD activities that are used to manage waste. Understanding the logic of activities provides a better understanding of the effect of these reengineering initiatives on streamlining waste management processes. WMRE involves cost-effective improvements of ongoing work practices accomplished by both WMRAD staff and waste generators.

WMRE is, therefore, an integral part of generator and WMRAD work, because ongoing activities will be streamlined. ORNL overhead funds will be used to foster the success of costeffective WMRE improvements. During the development of the WBS and resource-loaded schedule, assumptions were made that WMRAD and waste generators would support WMRE as necessary to make these cost-effective improvements. As FY 1998 funding allocations for WMRAD and Research Organizations are established, these assumptions will be verified. At that time, the combined (i.e., WMRAD, generator, ORNL overhead) schedule, milestones and budget will be finalized. The success of the reengineering effort will depend on changing the work practices of waste management staff and waste generators including research, support, and construction organizations. Therefore, a business strategy must be employed that promotes teamwork and rewards behaviors that lead to performance improvements and subsequent cost savings. Performance metrics will be developed for all contributing organizations, and WMRE progress will be measured, reported, and used to adjust plans.

\subsection{WASTE MANAGEMENT IMPLEMENTATION PLAN EXECUTION}

Reengineering is supported by ORNL overhead, WMRAD (through the EM program) and Research Organizations (through the ER program). ORNL overhead funds have been distributed to specific tasks to implement the reengineering effort. Both EM and ER have mutual interest in the success of WMRE. However, FY 1998 funds for WMRAD and 
generators are still being determined. Support for cost-effective improvements will be verified as budgets are finalized. Table 3, therefore, displays ORNL overhead funds allocated to specific tasks, while the fact that commitments are expected from WMRAD and ER is noted. The level of commitment from EM and ER programs is unknown at this time although anticipated commitments have been estimated (see Appendix C).

Performance metrics will be developed for each high-pay-back task: (1) Business Strategy; (2) Systems Analysis; (3) Waste Coordination Reengineering; (4) SLLW Process

Reengineering; (5) PWTP Reengineering; and (6) Requirements Evaluation and Elimination. Quantitative cost-effectiveness gains or qualitative improvements will be predicted and tracked. The transition of staff to more effective work practices is key to understanding WMRE success. As staff have time to accomplish more work because of efficiency gains, their work must be directed to result in streamlining waste handling from generation to disposal. For example, staff could complete shipping manifests for off-site disposal rather than revising and completing duplicate waste receipt paperwork. This type of transition will be difficult to measure, however. For WMRE to succeed, the effect on volume of waste processed (WM output) and/or unit cost must be tracked. Incentives developed through the business strategy will motivate these cultural changes and will be a basis for establishing performance metrics.

\section{Table 3. Summary of WMRE implementation work breakdown structure, overhead funding, and participating organizations}

\begin{tabular}{|c|c|c|c|}
\hline 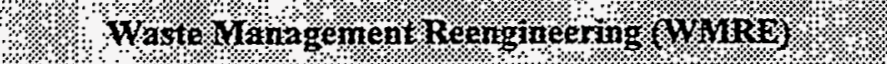 & \multicolumn{3}{|c|}{ Responsiblogysanizatrons: } \\
\hline 4. & 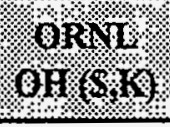 & Whingated & 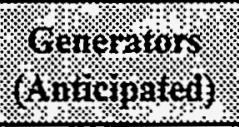 \\
\hline $\begin{array}{l}\text { 1.1 Best Business Practices } \\
\text { 1.1.1 Business Strategy and Approach } \\
\text { 1.1.2 Commercial Practices } \\
\text { 1.1.3 Communications } \\
\text { Subtotal }\end{array}$ & $\begin{array}{r}165 \\
10 \\
75 \\
250\end{array}$ & $\begin{array}{r}35 \\
5 \\
30 \\
70\end{array}$ & $\begin{array}{l}20 \\
10 \\
30 \\
60\end{array}$ \\
\hline $\begin{array}{l}\text { 1.2 Process Reengineering } \\
\text { 1.2.1 Systems Analysis } \\
\text { 1.2.2 Waste Coordination Reengineering } \\
\text { 1.2.3 Solid Low-Level Waste Process Reengineering } \\
\text { 1.2.4 PWTP Reengineering } \\
\text { 1.2.5 Requirements Evaluation and Elimination } \\
\text { 1.2.6 Waste Shipments to East Tennessee Technology Park } \\
\text { (ETTP) (not including characterization) } \\
\text { 1.2.7 Future Endeavors } \\
\text { Subtotal }\end{array}$ & $\begin{array}{r}250 \\
370 \\
200 \\
220 \\
5\end{array}$ & $\begin{array}{r}25 \\
1,385 \\
630 \\
\text { Being estimated } \\
\text { Implementation } \\
\text { Being estimated } \\
2,040\end{array}$ & $\begin{array}{r}\text { Review } \\
800 \\
300\end{array}$ \\
\hline $\begin{array}{l}\text { 1.3 Advanced Information Management Systems } \\
\text { 1.3.1 Upgrade of Current Waste Tracking System } \\
\text { 1.3.2 Creation of a Seamless WM Information Management } \\
\text { System } \\
\text { Subtotal }\end{array}$ & 150 & $\begin{array}{l}50 \\
40\end{array}$ & 40 \\
\hline Total $(\$, K)$ & 1,445 & 2,200 & 1,200 \\
\hline
\end{tabular}




\subsection{STRATEGY AND IMPLEMENTATION PLAN OVERVIEW}

WMRE benefits for DOE-EM and DOE-ER programs, ORNL management, and the M\&I contractor can be achieved if WMRE is supported by these organizations. The WMRE implementation team anticipates that this support can be gained through a logical approach that answers the following questions.

1. Why will ORNL staff have the incentive to make changes and implement reengineering? Staff will change because direct links will be made between their costeffective performance and the ability of Laboratory employees to retain responsibility for managing ORNL's waste.

2. What waste stream handling processes will be reengineered? In FY 1998, WMRE will focus on reengineering solid waste processes and eliminating the PWTP.

3. How will waste management reengineering reduce costs? Solid waste process steps will be eliminated or combined and less-costly categories of waste will be generated. WMRE will develop a design to combine the function of the PWTP with the Non-Rad Waste Water Treatment Plant.

Through development of the WBS, the WMRE implementation team developed a framework to answer these questions. The framework design includes three major WBS elements that serve as the structure for building the implementation strategy:

- Best Business Practices

- Process Reengineering

- Advanced Information Management Systems

Figure 2 illustrates how these three areas related through the WMRE process to answer the why, what, and how questions. The Best Business Practices section of the WBS establishes the framework and rationale for reengineering. The Process Reengineering section of the WBS establishes what must be reengineered including processes and data. It is the heart of WMRE and describes how costs will be cut through Reengineering Waste Coordination, Reengineering of the SLLW Process, and Reengineering the PWTP. The Advanced Information Management Systems section establishes a characterization, verification process, and feedback loop. These three areas are summarized in the following sections and details regarding each are included in Appendix B.

\subsection{BEST BUSINESS PRACTICES SUMMARY}

Best Business Practices (WBS 1.1) establish a sound business strategy (WBS 1.1.1) including incentives for ORNL staff to participate in cost-effective improvements. Best Business Practices support evaluation and implementation of cost-effective commercial practices (WBS 


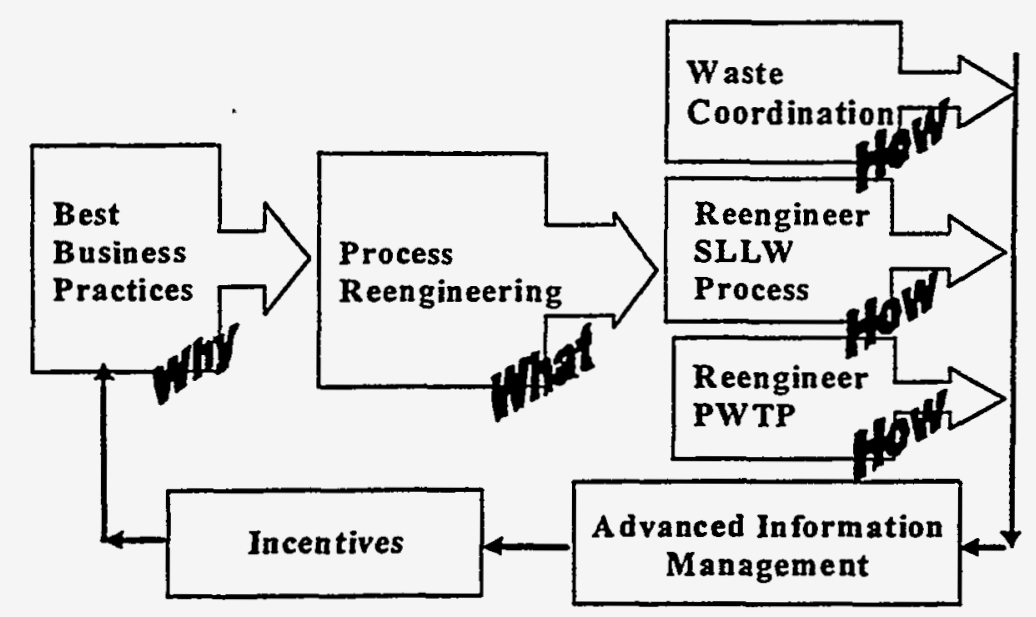

Fig. 2. WM Reengineering uses WBS to answer questions.

1.1.2), and identify and implement improvements for key communication issues to support cost-effective cultural change (WBS 1.1.3). Each of these are described in more detail in Section 4.0 of this report and in Appendix B.

\subsection{PROCESS REENGINEERING SUMMARY}

Process Reengineering (WBS 1.2) includes the systems analysis (WBS 1.2.1) task that will better describe the waste handling processes from generation to disposal and waste stream data. Process Reengineering also includes waste coordination between generators and WMRAD (WBS 1.2.2), the SLLW process (WBS 1.2.3), the PWTP (WBS 1.2.4), requirements evaluation and elimination (WBS 1.2.5), mixed waste shipments to ETTP (WBS 1.2.6), and future endeavors (WBS 1.2.7). Significant cost reductions are expected-from reengineering these processes. Each of these areas are described in more detail in section 5.0 of this report and in Appendix B.

\subsection{ADVANCED INFORMATION MANAGEMENT SYSTEMS SUMMARY}

The Advanced Information Management Systems (WBS 1.3) describes the completed task that upgraded the current waste tracking system (WTS) to provide DOE with the required data output through a waste information tracking system (WITS) interface capability (WBS 1.3.1). The focus of Advanced Information Management Systems is a task to restructure the existing waste information support system to provide a more seamless approach that encompasses the "cradle-to-grave" waste management process (WBS 1.3.2). Each of these areas are described in more detail in section 6.0 of this report and in Appendix B. 


\subsection{IMPLEMENTATION OF BEST BUSINESS PRACTICES}

The Best Business Practices WBS element establishes the framework and rationale for reengineering. It establishes a sound business strategy including incentives for organizational and individual participation in WMRE, supports the evaluation and implementation of costeffective commercial practices, and identifies and implements improvements for key communication issues to support cost-effective cultural change. Activities and due dates for implementing best business practices are specified in Table 4 .

\subsection{BUSINESS STRATEGY AND A.PPROACH}

A business strategy provides a rationale for organizations and individuals to participate in reengineering and guides implementation of the reengineering process. The objective of this WBS task is to establish a business strategy and approach for reengineering waste management at ORNL to support future growth while providing guidelines to streamline waste management processes. Implementation of this strategy will result in both Research Organizations and WMRAD becoming more competitive suppliers of their services. The business strategy will be used to support policy decisions on appropriate overhead rates for WMRAD. The costeffectivenessness of reengineering measures must be understood through quantitative and qualitative assessment of performance metrics. This task will develop a business strategy that is predicated on a performance-based incentive structure for waste management.

To accomplish these objectives, incentives for cost reduction must be understood and used to motivate institutional change. The WMRE business strategy focuses on three incentives:

1. For researchers to reduce time spent on waste management.

2. For researchers and generators to reduce and segregate waste at its source.

3. For WMRAD to accept performance risk (e.g., replace PWTP function, ship waste offsite).

The first two incentives will provide opportunities for growth in research. Researchers must be motivated to reduce time spent on waste management tasks and reduce waste at its source. Less time spent on waste management will provide time for researchers to improve the quality of their research and to propose additional research projects. Because the majority of ORNL's waste management funds are expended to manage newly generated waste, researchers and waste generators must also be motivated to reduce waste as it is generated through strong incentives for pollution prevention and waste segregation. The third incentive that is needed is the acceptance of performance risk to streamline waste processing. Individuals and managers must be rewarded rather than penalized for meeting performance objectives (such as shipping waste off-site for disposal). These combined incentives will reduce unit costs. The capability for the WMRAD administrative infrastructure to accomplish additional work will be increased while full compliance is maintained. In this way, more newly generated and legacy waste can be cost-effectively processed (see Appendix B, WBS 1.1.1). 
Table 4. Best business practices implementation strategy

\begin{tabular}{|c|c|c|c|}
\hline $\begin{array}{l}\text { WBS } 111 \\
\text { Best Business Practices }\end{array}$ & (4) & (2) & (1) \\
\hline $\begin{array}{l}\text { 1.1.1 Business Strategy } \\
\text { and Approach }\end{array}$ & $\begin{array}{l}\text { Researchers, } \\
\text { generators and } \\
\text { WMRAD motivated } \\
\text { to reduce costs. }\end{array}$ & $\begin{array}{l}\text { 1. WMRE develops incentives and performance } \\
\text { metrics. } \\
\text { 2. Customer Advisory Panel approves incentives. } \\
\text { 3. Incentives implemented and communicated } \\
\text { among researchers, generators, and WMRAD. } \\
\text { 4. Incentives and performance metrics tracked } \\
\text { and improved. }\end{array}$ & $\begin{array}{l}\text { 1. December } 1997 \\
\text { 2. January } 1998 \\
\text { 3. February } 1998 \\
\text { 4. September } 1998\end{array}$ \\
\hline $\begin{array}{l}\text { 1.1.2 Commercial } \\
\text { Practices }\end{array}$ & $\begin{array}{l}\text { ORNL viewed as a } \\
\text { single generator. } \\
\text { Cost-effective work } \\
\text { practices used. }\end{array}$ & $\begin{array}{l}\text { 1. Management support for Reengineering Waste } \\
\text { Coordination provided. } \\
\text { 2. Management advocacy provided for disposal } \\
\text { endpoints. } \\
\text { 3. Access to disposal streamlined; LMER } \\
\text { contracts awarded for SLLW and/or Mixed } \\
\text { Low-Level Waste (MLLW), if necessary. } \\
\text { 4. Craft support of Liquid, Gaseous Waste } \\
\text { Operating Group improved. }\end{array}$ & $\begin{array}{l}\text { 1. Level of effort } \\
\text { 2. Level of effort } \\
\text { 3. April } 1998 \\
\text { 4. March } 1998\end{array}$ \\
\hline 1.1.3 Communications & $\begin{array}{l}\text { Waste Management } \\
\text { becomes a service } \\
\text { provider. }\end{array}$ & $\begin{array}{l}\text { 1. Generators and Waste Management form } \\
\text { Customer Advisory Panel. } \\
\text { 2. Lockheed Martin management support } \\
\text { provided for proactive approach with DOE. } \\
\text { 3. Construction contracts changed to include } \\
\text { requirements for waste segregation. }\end{array}$ & $\begin{array}{l}\text { 1. September } 1997 \\
\text { 2. Level of effort } \\
\text { 3. July } 1998\end{array}$ \\
\hline
\end{tabular}




\subsection{COMMERCIAL PRACTICES}

ORNL must adopt commercial waste management practices to maintain its status as a worldclass research and development institution. Efficiency gains can be realized by recognizing ORNL as a single waste generator rather than 1,500 individual generators required to certify waste for disposal. Senior ORNL management will advocate improvements to waste management processes to ensure disposal endpoints are available and to institute pollution prevention. Greater efficiency and cost-effectiveness can be realized by pursuing waste acceptance criteria (WAC) waivers, collaborating with DOE complex initiatives to gain access to key endpoints, and adopting free-release standards. Streamlining the approval process for shipping wastes to off-site facilities will minimize duplicate reviews and delays in executing shipments (see Appendix B, WBS 1.1.2).

\subsection{COMMUNICATIONS}

The purpose of the Communications WBS task is to improve WMRAD communications, both internally with waste generators and construction project managers, and externally with $\mathrm{DOE}$ and the M\&I contractor. The specific objective is for WMRAD communications to be more generator-friendly while describing and implementing the incentive structure for generators to change work practices. Senior ORNL and WMRAD management will lead customer-oriented communications through participation on the Customer Advisory Panel. Senior management involvement in review and approval of cost-effective changes will provide a basis for communications with the M\&I contractor regarding ORNL waste management services (see Appendix B, WBS 1.1.3). 


\subsection{IMPLEMENTATION OF PROCESS REENGINEERING}

Process Reengineering includes the systems analysis task that will better describe the waste handling processes from generation to disposal and waste data. Process Reengineering also includes waste coordination between generators and WMRAD, the SLLW process, the PWTP, requirements evaluation and elimination, mixed waste shipments to ETTP, and future endeavors. Significant cost reductions are expected from reengineering these processes. Activities and due dates for Process Reengineering are specified in Table 5.

\subsection{SYSTEMS ANALYSIS}

A systems analysis will be performed on ORNL's waste generating and management processes to clearly describe activities that are used to generate and manage wastes. The analysis will determine an optimum approach for each waste stream, covering the range from generation to ultimate disposal. The Reengineering evaluation and report was the first phase of this effort.' To build on the foundation of this report, the processes that are being reengineered must be clarified to provide a foundation for waste management strategic planning. This high-level structure will allow analysis of the effect of changing one process activity on other process activities. Process activity logic diagrams will be documented for the major waste management processes. Waste type generation will be linked to disposal end-points. Data on waste types and generation rates support the systems analysis and provide the basis for waste forecasting and cost analyses. Existing process will be streamlined by implementing the 15 WMRE Core Team recommendations to more rapidly move waste from generation to disposal. Life-cycle costs will be evaluated for improvements such as reduction/elimination of specific waste types, operational changes, new or upgraded facilities, and outsourcing. Solid radioactive waste will be linked to off-site disposal end-points by April 1998 (see Appendix B, WBS 1.2.1).

\subsection{WASTE COORDINATION}

Reengineering of Waste Coordination is a key task within the Process Reengineering WBS. As benchmarked against Los Alamos National Laboratory by an ORNL reengineering team, WM experts facilitate transition to a WM customer service organization. Experts will apply a graded approach that includes use of process knowledge for waste characterization to minimize cost to researchers. This cornerstone of reengineering includes a data quality objective (DQO) approach to characterization, verification, certification, transport, storage, and disposal. Streamlining the SLLW process depends on the cooperation of researchers, waste generators, and WMRAD staff, as well as approvals from ORNL management and DOE. Incentives must be put in place to influence changes in behavior that will be required for success. Specific subordinate objectives of this task are to: (1) improve the ORNL Waste Certification process, (2) expand implementation of the Waste Coordination Team to additional divisions and to include pollution prevention to reduce researcher time spent on waste management 
Table 5. Process reengineering implementation strategy

\begin{tabular}{|c|c|c|c|}
\hline 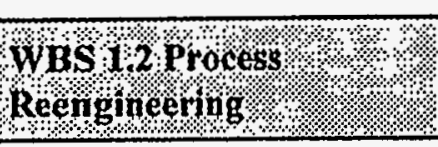 & \%: & I. & (1) \\
\hline $\begin{array}{l}\text { 1.2.1 Perform Systems } \\
\text { Analysis }\end{array}$ & $\begin{array}{l}\text { Streamlines } \\
\text { processes. } \\
\text { Views ORNL as a } \\
\text { single generator. }\end{array}$ & $\begin{array}{l}\text { 1. Complete process activity logic diagrams for all waste types. } \\
\text { 2. Complete white paper on disposal endpoints. } \\
\text { 3. Link SLLW and MLLW generation to disposal endpoints. } \\
\text { 4. Support SLLW/MLLW strategic planning with data. }\end{array}$ & $\begin{array}{l}\text { 1. December } 1997 \\
\text { 2. April } 1998 \\
\text { 3. April } 1998 \\
\text { 4. September } 1998\end{array}$ \\
\hline $\begin{array}{l}\text { 1.2.2 Reengineer Waste } \\
\text { Coordination }\end{array}$ & $\begin{array}{l}\text { Uses Waste } \\
\text { Management as } \\
\text { service provider. } \\
\text { Views ORNL as a } \\
\text { single generator. }\end{array}$ & $\begin{array}{l}\text { 1. Conduct assessments of Waste Certification Program. } \\
\text { 2. } \\
\text { 2. Implement auditable Waste Certification Program. } \\
\text { 3. Begin formalizing Generator/WM Memorandum of Understandings } \\
\text { (MOUs) for Generator Interface Group (GIG) services. } \\
\text { 4. Implement improved hazardous waste handling practices. } \\
\text { 5. Implement improved no-rad added program. }\end{array}$ & $\begin{array}{l}\text { 1. December } 1997 \text {, } \\
\text { March } 1998 \\
\text { 2. April } 1998 \\
\text { 3. January } 1998 \\
\text { 4. January } 1998 \\
\text { 5. April } 1998\end{array}$ \\
\hline $\begin{array}{l}\text { 1.2.3 Reengineer SLLW } \\
\text { Process }\end{array}$ & $\begin{array}{l}\text { Increases waste } \\
\text { handling capacities. }\end{array}$ & $\begin{array}{l}\text { 1. Complete cost analysis of SLLW incineration. } \\
\text { 2. Complete SLLW detailed process activity logic diagrams. } \\
\text { 3. Require generators to reduce SLLW initially by segregating sanitary } \\
\text { waste and SLLW. } \\
\text { 4. Ship suspect SLLW to sorting and free-release contractor. } \\
\text { 5. Reduce SLLW generation by } 15 / 25 \% \text {. }\end{array}$ & $\begin{array}{l}\text { 1. December } 1997 \\
\text { 2. December } 1997 \\
\text { 3. May } 1998 \\
\text { 4. May } 1998 \\
\text { 5. April/September } \\
1998\end{array}$ \\
\hline 1.2.4 Reengineer PWTP & Eliminates PWTP. & $\begin{array}{l}\text { 1. Evaluate options to replace PWTP function. } \\
\text { 2. Issue draft Request for Proposal (RFP) with use of LMER union } \\
\text { labor as requirement, OR } \\
\text { Initiate in-house project to replace PWTP. }\end{array}$ & $\begin{array}{l}\text { 1. December } 1997 \\
\text { 2. February } 1998\end{array}$ \\
\hline $\begin{array}{l}\text { 1.2.5 Perform } \\
\text { Requirements Evaluation } \\
\text { and Elimination }\end{array}$ & $\begin{array}{l}\text { Eliminates } \\
\text { unnecessary } \\
\text { requirements. }\end{array}$ & $\begin{array}{l}\text { 1. Re-negotiate/modify on-site waste transportation permits. } \\
\text { 2. Submit "necessary and sufficient" process results for approval. } \\
\text { 3. Evaluate "above and beyond" permit requirements. } \\
\text { 4. Complete plan to implement Resource Conservation and Recovery } \\
\text { Act (RCRA) permit modifications. }\end{array}$ & $\begin{array}{l}\text { 1. December } 1997 \\
\text { 2. December } 1997 \\
\text { 3. April } 1998 \\
\text { 4. July } 1998\end{array}$ \\
\hline
\end{tabular}


activities as determined through customer surveys, (3) implement ORNL's No-Rad Added Program to eliminate "policy mixed waste," and (4) implement specific pollution prevention initiatives (see Appendix B, WBS 1.2.2).

\subsection{SOLID LOW-LEVEL WASTE PROCESS}

The SLLW process must be reengineered because of the impending closure of the Interim Waste Management Facility (IWMF) and because of opportunities for significant reduction and segregation of SLLW at its source. Up to $60 \%$ of waste declared as SLLW is actually non-radioactive. The WMRE strategy is to segregate waste, thereby reducing the quantities of waste that are costly to treat (i.e., SLLW) in favor of those that are less costly (i.e., sanitary/industrial and suspect radioactive) (see Fig. 3). Incineration of SLLW will dramatically reduce characterization costs and reduce the volume of waste requiring storage until the Nevada Test Site (NTS) is available for disposal. ORNL will place contracts for segregation of suspect waste to free-release non-

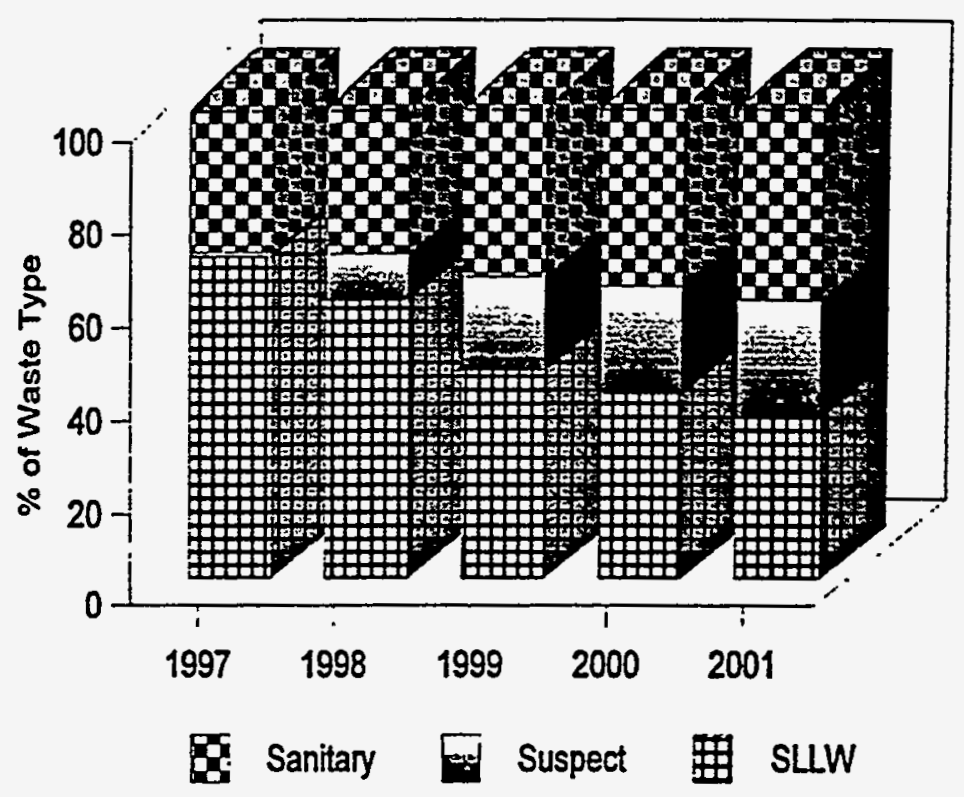
radioactive waste and to incinerate SLLW (see Appendix B, WBS 1.2.3).

\subsection{PROCESS WASTE TREATMENT PLANT}

The PWTP removes radionuclides from process wastewater. This process generates liquid lowlevel waste (LLLW) that is stored in the Melton Valley Storage Tanks, ORNL's most costly waste stream. Technology is available to replace this radionuclide removal process with a more cost-effective process. This task will determine if the function of the PWTP can be replaced by using existing equipment at the Non-Radiological Wastewater Treatment Plant (NRWTP). An engineering feasibility study will be completed to establish whether existing columns that are used for removal of organic components from non-radioactive wastewater using granulated activated carbon (GAC) can be modified to accept zeolites that remove radionuclides from process wastewater. Treatment to meet National Pollution Discharge Elimination System (NPDES) requirements for non-radioactive wastewater must not be affected by the proposed 
option. The capital cost of the modification will be determined. A decision will be made in December 1997, based on the results of the feasibility study, whether in-house replacement or subcontract replacement of the PWTP is the most cost-effective approach.

Line Item capital projects have not been approved to upgrade the PWTP. Therefore, if significant capital is required to upgrade the NRWTP to replace the function of the PWTP, the reengineering strategy is to award a performance-based service contract for improved technology. ORNL would pay a service contractor for each gallon of waste that is treated to meet performance standards. Placing performance risk on the service contractor relieves DOE from expending capital funds to make process improvements. Contract terms and conditions will define the way in which LMER labor will be used and specify resolution of permit, liability, and operating issues. Incentives for ORNL to accept and negotiate performance risk must be in place to reward those who implement a more cost-effective process (see Appendix B, WBS 1.2.4).

\subsection{REQUIREMENTS EVALUATION AND ELIMINATION}

Waste management processes are conducted per regulatory and customer-mandated requirements. WMRAD is evaluating and eliminating "requirements" through approved channels. As budgets decline, some requirements can be modified to more cost-effective approaches. The requirements being evaluated and modified include: on-site Department of Transportation (DOT) equivalency, RCRA permit requirements, "necessary and sufficient" DOE orders, and the related conduct of operations. Operating procedures will be modified to align work practices with reduced or eliminated requirements (see Appendix B, WBS 1.2.5).

\subsection{MIXED WASTE SHIPMENTS TO ETTP}

WMRAD staff are actively pursuing shipment of mixed waste to ETTP. Administrative (e.g., documentation, approvals) and funding issues are being resolved by DOE-OR, ETTP, and WMRAD staff. WMRE supports this important initiative. No ORNL overhead nor waste generator involvement is required to resolve issues (see Appendix B, WBS 1.2.6).

\subsection{FUTURE ENDEAVORS}

Additional actions were identified by the WMRE Core Team and process teams, but were given lower priority for implementation. These actions included expanded use of the Oak Ridge Y-12 Site landfill for ORNL wastes and use of Buildings 3517 and 3525 for waste treatment. After the WMRE initial high-pay back tasks are clearly proceeding as planned, these suggested actions may be reevaluated. In addition, the ongoing WMRE tasks may identify future actions that would further reduce costs. These actions, which may be identified in the future, will be placed in this WBS so the appropriate course of action can be determined. 


\subsection{IMPLEMENTATION OF INFORMATION MANAGEMENT SYSTEMS}

WMRE will create a waste characterization, verification, and certification system based on a DQO process to determine optimal ways to establish waste composition. Using the WM reengineered system, experts will fully integrate data for characterization, verification, transportation and disposal end-points. Improvements include "real time" inventory management, compliance tracking, shipment planning, and requirement reporting. The current practice of verifying compliance with WAC after waste is packaged may be revised to result in significant cost savings. A position paper will be drafted to evaluate the benefits and costs of an improved approach. The WMRE objective is to develop a system that allows ORNL to become a single generator by identifying opportunities for co-mingling waste so it can be more costeffectively disposed. Data tracking and acquisition will be improved by developing and implementing advanced information management tools and forms. Activities and due dates are specified in Table 6.

Table 6. Advanced information management systems implementation strategy

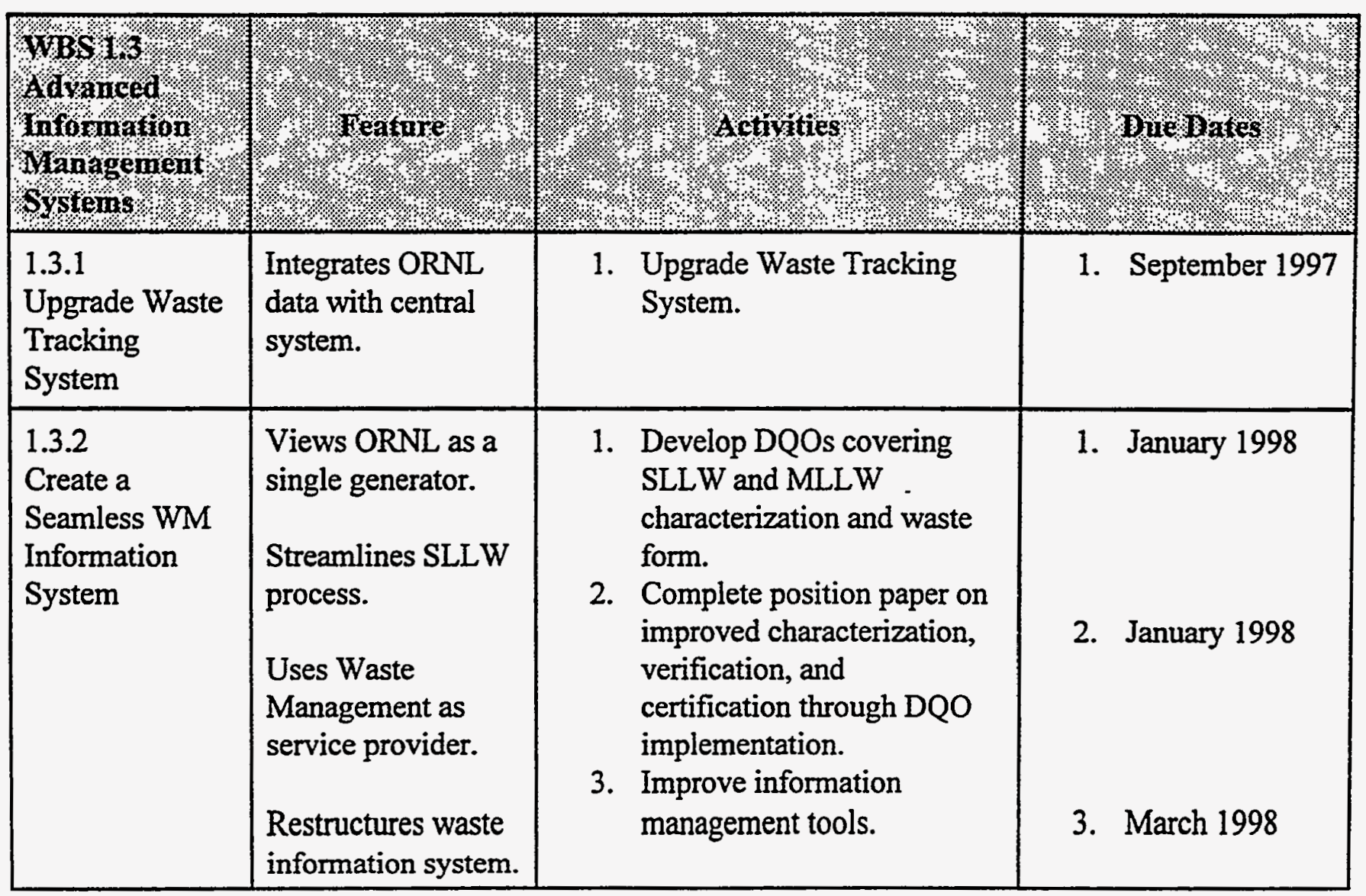




\subsection{WASTE TRACKING SYSTEM}

The WMRE Core Team recommended upgrade of the ORNL WTS to provide DOE with the required data output to interface with the WTTS. This recommendation was approved and implemented in FY 1997. The WITS interface capability allows ORNL to propose a costeffective interface with WITS to DOE-EM. Depending on DOE approval, ORNL will continue adjustments to WTS to accomplish the DOE-OR objective of reporting to a centralized database. The WMRE initiative has been completed.

\subsection{WASTE INFORMATION MANAGEMENT SYSTEM}

The task to create a single, expert-based ORNL waste characterization, verification, certification program and organization, relies on the deployment of systems, technology, and experts for the characterization of waste. This expert-based system will enable other WMRE Core Team recommendations to be realized, for example: (1) improved tools and forms for use by waste generators and generator interface staff; (2) an engineered approach to no-rad added determinations; (3) a waste management strategy to eliminate, reduce, aggregate, treat, and match waste streams to an endpoint, (4) an approach to characterization that will demonstrate that DQOs are satisfied based on meeting necessary-and-sufficient requirements of DOE, regulators, or disposal endpoints;

(5) vital information provided to the advanced information Management Systems, including auditable isotope assay data, associated uncertainties, and process variability; and (6) teaming with Research Organizations, WMRAD, and the WMRE Process Reengineering Task.

This task will develop a proposal to restructure the existing waste information support system to provide a more seamless approach that encompasses the "cradle-to-grave" waste management process. The reengineered system will be fully integrated throughout the entire waste management process, providing "real-time" inventory management, compliance tracking, shipment planning, and requirement reporting. This seamless waste management information system will link characterization, verification, DQOs, transportation, and disposal end-points. Implementation of this vision requires a clear understanding of how current activities are conducted and how they should be changed to achieve cost-effectivenessness. This task will develop a plan, obtain review and approval of concepts, and secure approval for the selected approach. The goal is to reengineer existing generator and WMRAD activities so costeffectiveness gains can be redirected to a more efficient process that will result in ORNL waste disposal and an increase in the capability of ORNL to manage waste at low unit costs. 


\subsection{WASTE MANAGEMENT REENGINEERING IMPLEMENTATION BENEFITS}

Implementation of the WMRE is expected to benefit DOE-EM, DOE-ER, ORNL, and the M\&I contractor. Table 7 outlines the key benefits of each WMRE feature. These features are based on details of the WMRE Implementation Plan as presented in Tables 4, 5, and 6 by WBS element and task.

Table 7. Key features and benefits

\begin{tabular}{|c|c|}
\hline 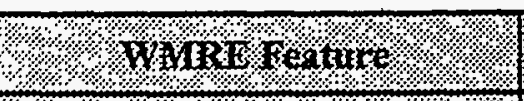 & 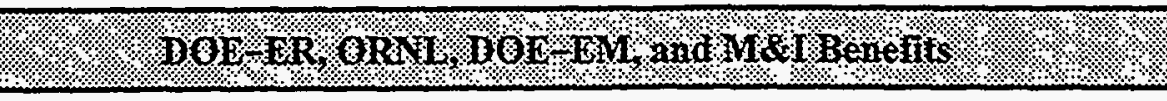 \\
\hline 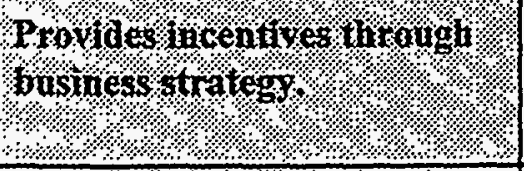 & $\begin{array}{l}\text { - Motivates researchers, waste generators, and WMRAD staff to change } \\
\text { to more cost-effective work practices. } \\
\text { - Rewards performance (e.g., waste disposal). }\end{array}$ \\
\hline generator & $\begin{array}{l}\text { - Reduces generators from } 1500 \text { to one. } \\
\text { - Implements DQOs. } \\
\text { - Streamlines processes from generation to disposal. }\end{array}$ \\
\hline Streamines S 6 W process & $\begin{array}{l}\text { - Customizes services for waste type (e.g., process routine waste } \\
\text { quickly; implement controls for unique wastes). } \\
\text { - Reduces waste generated through pollution prevention. } \\
\text { - Reduces time to process and dispose of waste. }\end{array}$ \\
\hline uses Waste nanogerment as & $\begin{array}{l}\text { Provides expertise specific to generator. } \\
\text { - Consults on best practices. } \\
\text { - Expedites paperwork. } \\
\text { Provides single point of contact for pollution prevention and waste } \\
\text { disposal consolidating } 1500 \text { waste generators. } \\
\text { Provides growth opportunity to expand service organization. }\end{array}$ \\
\hline mapability waste handing & $\begin{array}{l}\text { Provides ability to accept more waste and process cost-effectively. } \\
\text { - Newly generated waste due to increased energy research. } \\
\text { - Legacy waste from M\&I contractor. }\end{array}$ \\
\hline Eliminates PW & $\begin{array}{l}\text { - Reduces operating cost. } \\
\text { - Reduces process complexity. } \\
\text { - Eliminates high-volume, high-mass, LLLW stream. }\end{array}$ \\
\hline Fiminates unnecessaty & $\begin{array}{l}\text { - Streamlines work practices. } \\
\text { - Increases staff time to accept more waste handling tasks. }\end{array}$ \\
\hline Restructuresyaste & $\begin{array}{l}\text { - Streamlines waste characterization, verification, and certification by } \\
\text { linking with DQO process. } \\
\text { - Provides "real-time" inventory management, compliance tracking, } \\
\text { shipment planning, and requirement reporting. }\end{array}$ \\
\hline
\end{tabular}




\subsection{SUMMARY AND CONCLUSIONS}

\subsection{SUMMARY}

As described in Section 3, Strategy and Implementation Plan Overview, the success of DOE-EM and DOE-ER programs, ORINL management, and the M\&I contractor through WMRE initiatives depends on their support. The WMRE implementation team anticipates that this support can be gained through a logical approach that answers the following questions.

1. Why will ORNL staff have the incentive to make changes and implement reengineering?

2. What waste stream handling processes will be reengineered?

3. How will waste management reengineering reduce costs?

The relationship between these questions and the three WBS elements (i.e., Best Business Practices, Process Reengineering, and A.dvanced Information Management Systems) is described throughout this Implementation Plan (also see Fig. 2). Answers to these questions have, therefore, been provided and are summarized below.

\section{Why will ORNL staff have the incentive to make changes and implement reengineering?}

Staff will change because direct links will be made between their cost-effective performance and the ability of Laboratory employees to retain responsibility for managing ORNL's waste. The WMRE Core Team reviewed prelininary Implementation Plans and concurred that WMRE must focus on the following incentives to motivate change. Without these incentives, it is unlikely that reengineering goals will be achieved. The Best Business Practices section of the WBS provides details about how such incentives will be developed.

- Incentive to reduce researcher time on waste management.

- Incentive to reduce and segregate waste at its source.

- Incentive to accept performance risk (e.g., replace PWTP function, ship waste off-site).

Three types of incentives must be implemented. Effective implementation of the first two incentives will provide opportunities for growth in research. The third incentive requires acceptance of performance risk to streamline waste processing. These combined incentives will reduce unit costs and free capability in the existing WMRAD infrastructure to process more newly generated waste and legacy waste.

\section{What waste stream handling processes will be reengineered?}

In FY 1998, WMRE will focus on reengineering solid waste processes and eliminating the PWTP. Although candidate waste stream handling processes have been identified for reengineering, waste stream data requirements and process details must be identified through a 
systematic process. A systems analysis will be performed to clearly describe activities that are conducted to manage waste. Process activity logic diagrams will represent the "as is" waste management process. With the current operating practices specified, existing processes can be streamlined to more rapidly move waste from generation to disposal. Data on waste types and generation rates support the systems analysis and provide the basis for waste forecasting and life-cycle cost analyses. The systems analysis forms the framework for all reengineering projects.

\section{How will waste management reengineering reduce costs?}

WMRE will reduce costs by initially focusing on high-payback projects. Because of the size and complexity of WMRE, a logical priority must be established to guide the implementation teams and provide consistent communication to management. Reengineering of waste coordination, the SLLW process, and PWTP are the three highest WMRE priorities.

The success of the following tasks depends on the success of the business strategy and systems analysis even though these tasks were assigned lower priority. Priority rankings were established based on those projects that would be funded if funding were limited to one project. Therefore, specific process reengineering projects are given the highest priority.

Priority 1: Waste coordination and improving the customer service orientation of waste management is the vehicle for achieving cost-effectiveness gains for both Research and Waste Management Organizations. Since the waste coordination task implements waste management as a service provider and cost-effectiveness gains are expected to be significant, this project has the highest priority.

Priority 2: The SLLW process is ripe for improvements since up to $60 \%$ of the waste stream may be inappropriately categorized causing processing to be more costly. In addition, closure of the ORNL on-site disposal facility is eminent. Because of the high potential for cost savings and the potential that research could be stopped if the disposal outlet is unavailable, reengineering the SLLW is the second highest priority.

Priority 3: Elimination of the PWTP is another high pay-back project. Due to the aging condition of existing treatment process and the potential to replace the facility with a more cost-effective process, this project is the third highest priority.

Priority 4: An incentive structure developed through Best Business Practices will be implemented to compel organizational change.

Priority 5: A Systems Analysis will be performed to provide the basis for the incentive structure, strategic planning, and decision making. 
Priority 6: Waste-tracking forms and information collection tools (e.g., barcode system) will be upgraded to meet EM requirements more cost-effectively.

Priority 7: Evaluation and elimination of requirements is an ongoing activity within WMRAD and will not require significant contributions from WMRE implementation.

Priority 8: Performance metric tracking is important to understand the cost-effectiveness of the high priority tasks.

Priority 9: The proposal to create a seamless waste information system is expected to demonstrate that cost recovery for improvements can occur within one year. This task would then be "self-supporting," because savings would off-set costs.

\subsection{CONCLUSION}

Reengineering can help to reverse current trends and focus on making researchers more competitive while reducing costs for both DOE-EM and DOE-ER. Competitive ORNL waste management services achieved through WMRE initiatives will benefit DOE, the M\&I contractor, and ORNL. Even though budgets are declining, a vision for growth can emerge from the current situation. Cost-effective, expert-based waste management services with streamlined waste management processes offer this vision for growth (see Table 8).

Table 8. A vision for growth

\begin{tabular}{|c|c|c|}
\hline (2) & 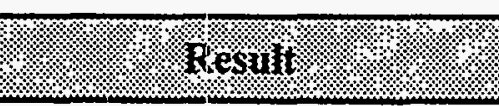 & 4.4 Grouthi \\
\hline $\begin{array}{l}\text { Increased productive } \\
\text { researcher finime }\end{array}$ & $\begin{array}{l}\text { More researc } \\
\text { proposed and } \\
\text { to ORNL. }\end{array}$ & - More DO \\
\hline 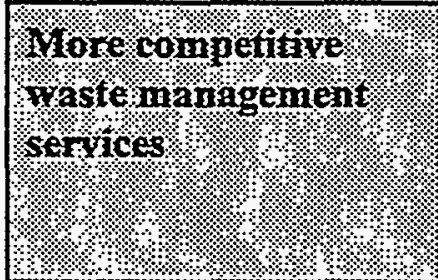 & $\begin{array}{l}\text { More capability to } \\
\text { process newly } \\
\text { generated waste. } \\
\text { More capability to } \\
\text { process legacy waste. }\end{array}$ & $\begin{array}{l}\text { - More DOE-EM benefits } \\
\text { - More ORNL business } \\
\text { - More cost-effective legacy } \\
\text { waste processing at ORNL } \\
\text { for M\&I contractor }\end{array}$ \\
\hline $\begin{array}{l}\text { Streaminingdexpert } \\
\text { Yaste managenent } \\
\text { System }\end{array}$ & - $\begin{array}{l}\text { More } \\
\text { opport }\end{array}$ & $\begin{array}{l}\text { More DOE complex } \\
\text { benefits } \\
\text { - More ORNL business }\end{array}$ \\
\hline
\end{tabular}




\section{REFERENCE}

1. Myrick, T. E., Reengineering of Waste Management at the Oak Ridge National Laboratory, ORNL/TM-13488, August 1997. 
APPENDIX A

WASTE MANAGEMENT REENGINEERING CORE TEAM RECOMMENDATIONS 


\section{WASTE MANAGEMENT REENGINEERING CORE TEAM RECOMMENDATIONS}

The 15 cost-effectiveness recommendations by the Core Team are explained in detail in Appendix A. Recommendations were developed by eight Process Teams and consolidated by the Core Team during the summer of 1997 (see ORNL/TM-13488). These improvements are expected to reduce ORNL waste management costs by $\$ 10-15 \mathrm{M}$ annually, as compared to the FY 1996 costs of \$75M.

A map follows the list of recommendations, showing how they fit under the three main elements of the work breakdown structure: best business practices, process reengineering, and advanced information management systems. Completed actions and tabled recommendations are also listed. 


\begin{tabular}{|c|c|c|c|}
\hline $\begin{array}{c}\text { Process Team } \\
\text { Designation }\end{array}$ & Recommendation & WBS & Responsible Party \\
\hline$\overline{C V}-1$ & $\begin{array}{l}\text { Develop a Waste Certification Model: Reorient WM at ORNL to embody a system in which ORNL becomes } \\
\text { the one single generator wilh the research organizations being the customer of the WM service organization. } \\
\text { This should enable the laboratory to consolidale what are today consolidate what are loday considered as } \\
\text { individual waste streams into broader "ORNL waste streams" that are then certified by the laboratory prior to }\end{array}$ & 1.3 .1 & Scanilan \\
\hline
\end{tabular}

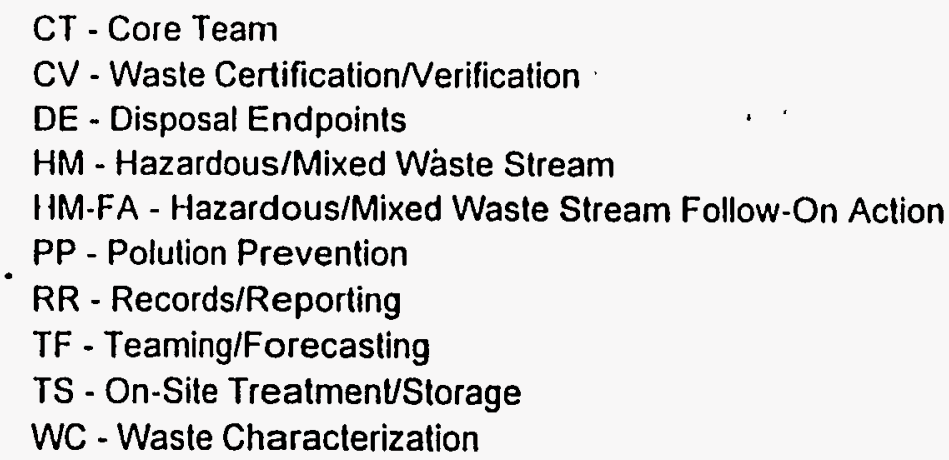




\section{Core Team Recommendation \#2: Shift WM Customer Service Orientation to Include DOE-EM, Research Organizations,}

- and $M$ and I Contractor

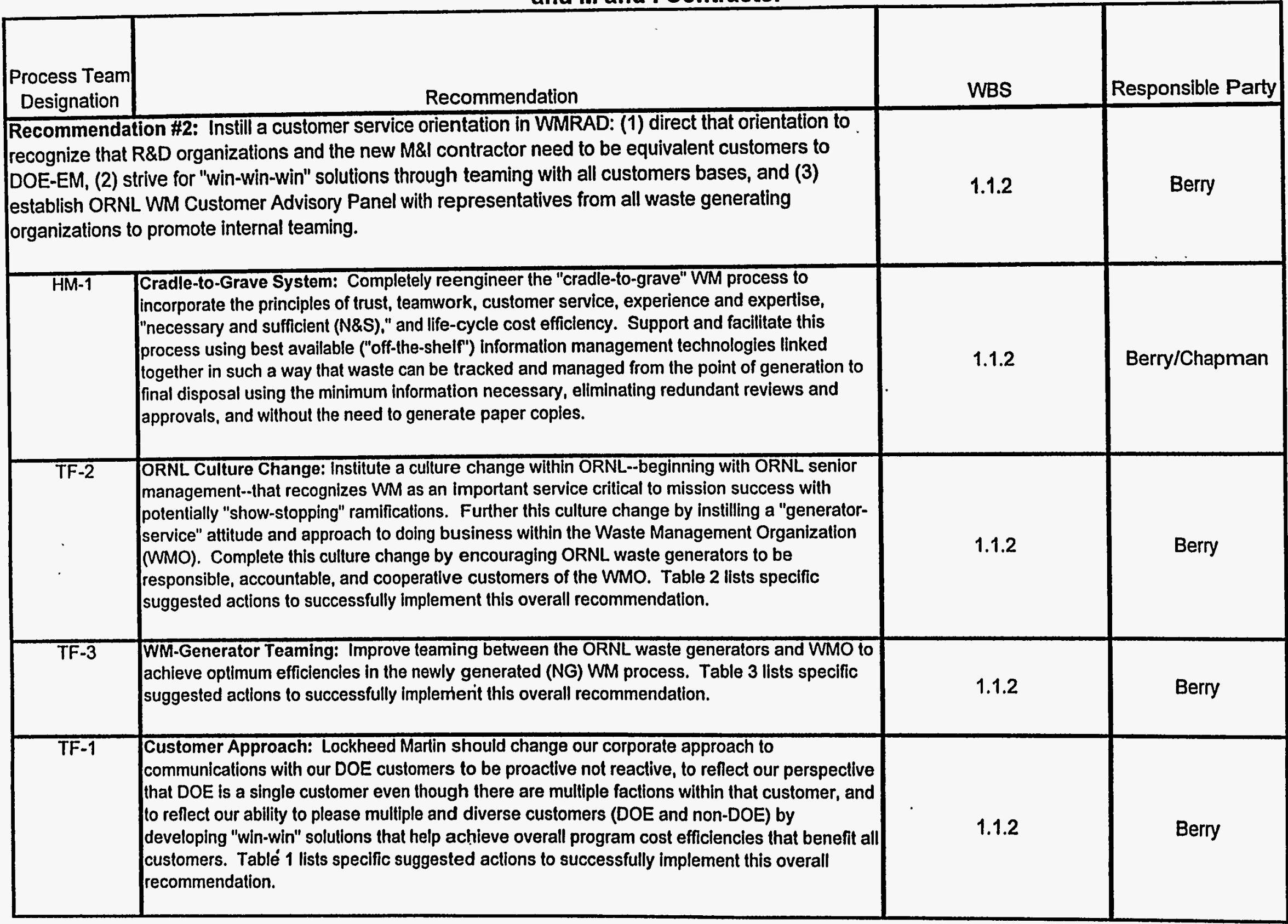


Core Team Recommendation \#3: Perform Systems Analysis as the Basis for WM Strategic Planning

\begin{tabular}{|c|c|c|c|}
\hline $\begin{array}{c}\text { Process Team } \\
\text { Designation }\end{array}$ & Recommendation & WBS & $\begin{array}{l}\text { Responsible } \\
\text { Party }\end{array}$ \\
\hline \multicolumn{2}{|c|}{$\begin{array}{l}\text { Recommendation \#3: Perform a comprehensive Systems Analysis of ORNL waste as the basis for WM } \\
\text { strategic planning: (1) evaluate present and future waste streams and generation rates, (2) identify } \\
\text { optimal treatment/disposal methods for present and future waste streams, and (3) evaluate options to } \\
\text { implement the optimal treatment/disposal methods (e.g., new or upgraded facilities, operational changes, } \\
\text { outsourcing, etc.) with consideration of life-cycle costs. }\end{array}$} & 1.2.1 & Trabalka \\
\hline$\overline{D E-1}$ & Investment Endpoints: ORNL should invest more to ensure endpoint availability. & 1.2 .1 & Trabalka \\
\hline$\overline{D E-2}$ & $\begin{array}{l}\text { Pursue Waivers: ORNL's contingency option to a newly inaccessible endpoint should be to } \\
\text { pursue waivers. }\end{array}$ & 1.2 .6 & \\
\hline$\overline{D E-3}$ & $\begin{array}{l}\text { Endpoints Cradle-to-Grave: ORNL should adopt endpoint-focused cradle-to-grave waste } \\
\text { management: (a) Systems analysis is required to fully understand and optimize the system, and } \\
\text { (b) Order } 435.1 \text { will require this (if promulgated). }\end{array}$ & 1.2 .1 & Trabalka \\
\hline$\overline{\mathrm{DE}-4}$ & $\begin{array}{l}\text { Dispositons Known Before Generators: Wastes should be produced with dispositions as the } \\
\text { foremost thought: (a) Will require a true team effort, generators cannot regard their wastes as } \\
\text { someone else's problem, (b) Permit to generate a new waste type?, (c) Pedigree and package } \\
\text { wastes at time of generation, (d) Make process knowledge acceptable basis for waste pedigree, } \\
\text { (e) Study needed (1) How to do so with newly generated wastes and (2) Propose solution for } \\
\text { intractable waste or cease generation. }\end{array}$ & 1.2 .1 & Trabalka \\
\hline$\overline{D E}-6$ & $\begin{array}{l}\text { Nevada Test Site (NTS)/Hanford: (a) Focus on NTS for liquid low-level waste (LLW) and Hanford } \\
\text { for mixed LLW and (b) send both LLW and mixed waste to one site. }\end{array}$ & 1.2 .1 & Trabalka \\
\hline$\overline{D E-7}$ & $\begin{array}{l}\text { Waste Isolation Pilot Plant/Project (WIPP) for \&ransuranic (TRU): Must use WIPP for TRU but } \\
\text { be prepared for long-term storage. }\end{array}$ & 1.2.1 & Trabalka \\
\hline DE-13 & $\begin{array}{l}\text { Radically Altered Endpoints: Feasibility studies of radically altering some waste endpoint } \\
\text { requirements: (a) Outfalls: Eliminate all liquid discharges, (b) Mixed Waste: Minimize RCRA } \\
\text { materials, make all wastes non-RCRA and (c) RH-TRU: Separate into RH-LLW (to NTS) and CH- } \\
\text { TRU (more reliably to WIPP). }\end{array}$ & 1.2 .6 & Trabalka \\
\hline WC-1 & Systems Analysis: Perform systems analysis to guide management of ORNL wastes. & 1.2 .1 & Trabalka \\
\hline
\end{tabular}


Core Team Recommendation \#4: Establish Direct ORNL Involvement with Disposal Endpoints

\begin{tabular}{|c|c|c|c|}
\hline $\begin{array}{c}\text { Process Team } \\
\text { Designation }\end{array}$ & Recommendation & WBS & $\begin{array}{l}\text { Responsible } \\
\text { Party }\end{array}$ \\
\hline \multicolumn{2}{|c|}{$\begin{array}{l}\text { Recommendation \#4: Establish direct ORNL involvement with disposal endpoints: (1) take lead in } \\
\text { representing ORNL's present and future interests regarding newly generated waste, rather than the new } \\
\text { M\&l filling that role, (2) become involved with regulatory and political aspects of ensuring disposal } \\
\text { endpoint available for ORNL present and future waste, and (3) accelerate shipment of legacy waste to } \\
\text { East Tennessee Technology Park (ETTP). }\end{array}$} & 1.1 .2 & Beriy \\
\hline DE-10 & $\begin{array}{l}\text { Activist Role: Adopt an activist role regarding endpoints: (a) ldentify endpoint managers, } \\
\text { (b) Collaborate with other labs to work the system - Strategic Lab Council?, and (c) Involvement in } \\
\text { advisory/technical/steering committees related to WIPP, NTS, Hanford. }\end{array}$ & 1.1 .2 & Berry \\
\hline DE-11 & Y-12 Landfill Performance Assessment (PA): Development of Y-12 Industrial Landfill PA. & 1.2 .6 & $\mathrm{n} / \mathrm{a}$ \\
\hline DE-12 & $\begin{array}{l}\text { State Equity: Actively recognize and manage state equity balance to provide leverage for } \\
\text { endpoint access and reduce unit disposal costs - CONCEPT: Become a treatment, storage, } \\
\text { packaging, and shipping depot for the eastern United States: (a) On the way for many eastern } \\
\text { siles, (b) Capitalize on expertise in some waste types, and (c) Attuned to Western needs: } \\
\text { minimum voids, maximum stability. }\end{array}$ & 1.2 .6 & $\mathrm{n} / \mathrm{a}$ \\
\hline$\overline{D E}-14$ & $\begin{array}{l}\text { New Site for Troublesome Waste: Feasibility study of ORNL taking the lead in establishing a } \\
\text { new waste disposal site for intermediate-level or otherwise troublesome wastes: (a) Focus on } \\
\text { NTS, (b) LM complex-wide initiative on government land?, and (c) LM commercial initiative on } \\
\text { leased land? }\end{array}$ & 1.2 .6 & $\mathrm{n} / \mathrm{a}$ \\
\hline DE-15 & $\begin{array}{l}\text { Melton Valley Storage Tank (MVST)/TRU Sub: Encourage the MVST/TRU solid waste } \\
\text { contractor to use } 3517 \text { and } 3525 \text { to process legacy wastes leading to a continuing capability to } \\
\text { handle newly generated wastes. }\end{array}$ & 1.2 .6 & n/a \\
\hline TS-5 & Ship Mixed Waste to ETTP: Accelerate and maximize mixed waste shipments to ETTP.: & 1.2 .6 & $\mathrm{n} / \mathrm{a}$ \\
\hline
\end{tabular}


Core Team Recommendation \#5: Create a Single, Expert-based ORNL Waste Characterization/Verification/Certification Program and Organization

\begin{tabular}{|c|c|c|c|}
\hline $\begin{array}{l}\text { Process Team } \\
\text { Designation }\end{array}$ & Recommendation & WBS & Party Responsible \\
\hline \multicolumn{2}{|c|}{$\begin{array}{l}\text { Recommendation \#5: Create an expert-based ORNL waste characterization/verification/certification } \\
\text { program and organization within WM: (1) place responsibility for proper characterization on WM } \\
\text { experts rather than individual researchers, (2) apply an expert-based, graded approach to } \\
\text { characterization, including use of process knowledge (PK), and (3) ensure appropriate DQOs and } \\
\text { WACs are met. }\end{array}$} & 1.2 .2 & $\begin{array}{l}\text { Waste Cóordination } \\
\text { Teäm }\end{array}$ \\
\hline$\overline{C V}-2$ & $\begin{array}{l}\text { Adopt the Proposed Waste Certification (WC) Model (1) Continue development and } \\
\text { implementation of the Generator Interface Group; (2) Develop a consistent, verified, and } \\
\text { validated approach to characterization. }\end{array}$ & 1.2 .2 & $\begin{array}{l}\text { Waste Coordination } \\
\text { Team }\end{array}$ \\
\hline $\mathrm{CV}-3$ & $\begin{array}{l}\text { Validate The WC Process: Validate the waste certification process through assessments and } \\
\text { audits. }\end{array}$ & 1.2 .2 & $\begin{array}{l}\text { Waste Coordination } \\
\text { Team }\end{array}$ \\
\hline$\overline{C V-4}$ & $\begin{array}{l}\text { Verify Individual Containers: Develop the means for determining and performing verification } \\
\text { through a DQO process. }\end{array}$ & 1.3.2 & $\begin{array}{l}\text { Waste Coordination } \\
\text { Team }\end{array}$ \\
\hline CV-5 & $\begin{array}{l}\text { Deploy Technology: Deploy technology for measuring radionuclide quantity or consideration } \\
\text { of treatment technologies for specific waste streams [i.e., TRU concentration determination } \\
(100 \mathrm{nCi} / \mathrm{g}) \text { or "no-rad was added"]. }\end{array}$ & 1.3.2 & Chapman \\
\hline $\mathrm{CV}-6$ & $\begin{array}{l}\text { Evaluate Use of PK: Evaluate process knowledge under a set of boundary conditions. Make } \\
\text { upper management aware of potential business risks associated with PK and evaluate liability } \\
\text { on a laboratory basis, not at a waste certifier level. }\end{array}$ & 1.3.2 & $\begin{array}{l}\text { Waste Coordination } \\
\text { Team }\end{array}$ \\
\hline HM-FA-2 & $\begin{array}{l}\text { Sampling and Analysis: Evaluate potential cost savings in analylical work -- off-site } \\
\text { analysis/sampling services. }\end{array}$ & 1.3.2 & $\begin{array}{l}\text { Waste Coordination } \\
\text { Team }\end{array}$ \\
\hline WC-2 & $\begin{array}{l}\text { Characterization System: Move characterization of ORNL radioactive waste to an expert- } \\
\text { based system. }\end{array}$ & 1.3 .2 & Chapman \\
\hline
\end{tabular}


Core Team Recommendation \#6: Modify the ORNL SLLW Management Process to Mimic the Commercial Nuclear Industry

\begin{tabular}{|c|l|c|c|}
\hline $\begin{array}{c}\text { Process } \\
\text { Team } \\
\text { Designation }\end{array}$ & \multicolumn{1}{|c|}{ Recommendation } & WBS & Party Responsible \\
\hline $\begin{array}{l}\text { Recommendation \#6: Modify the ORNL SLLW management process to mimic that of the commercial } \\
\text { nuclear industry: (1) segregate "reducible" waste at source and survey for free release, and (2) centrally } \\
\text { treat/process contaminated waste for maximum volume reduction and dispose of residual with } \\
\text { characterization that takes advantage of homogenization. }\end{array}$ & 1.2 .3 \\
\hline PP-1 & $\begin{array}{l}\text { SLLW Management: Revamp the SLLWProgram to include SLLW pickup and packaging by } \\
\text { WMRAD on a per item (package) basis. }\end{array}$ & 1.2 .3 & Michaud \\
\hline PP-16 & $\begin{array}{l}\text { Health Physics (HP) Green Tag: Clarify HP green-tag procedures and train every HP at the Lab. } \\
\text { Follow lab-wide procedures for green-tagging so that it is possible for clean materials to be tagged as } \\
\text { such. Orient HP technicians to a service approach, such as analytical chemists are, in the waste } \\
\text { disposal process. }\end{array}$ & 1.2 .3 \\
\hline TS-4 & $\begin{array}{l}\text { SLLW Management: Modify existing SLLW management process to (1) use off-site "free release" } \\
\text { service, and (2) maximize off-site volume reduction when supported by favorable benefit-cost } \\
\text { analysis results. }\end{array}$ & 1.2 .3 \\
\hline WC-3 & $\begin{array}{l}\text { Communicate No Rad-Added: Deploy ORNL equivalent of accepted nuclear industry practices to } \\
\text { segregate uncontaminated waste from SLLW at the source and to dispose of uncontaminated } \\
\text { materials in the Y-12 landfill. }\end{array}$ & Michaud \\
\hline
\end{tabular}




\section{Core Team Recommendation \#7: Create a "Seamless" WM Information Management System}

\begin{tabular}{|c|c|c|c|}
\hline $\begin{array}{c}\text { Process Team } \\
\text { Designation }\end{array}$ & Recommendation & WBS & Responsible Party \\
\hline \multicolumn{2}{|c|}{$\begin{array}{l}\text { Recommendation \#7: Create a seamless WM information management system utilizing avaliable technology to } \\
\text { the maximum benefit of both WM and its customers: (1) implement improvements to fully utilize and integrate } \\
\text { present components of the system, (2) tailor system to meet ORNL needs, not needs of all five OR sites, and } \\
\text { (3) ensure future additions or modifications of components "fit" the integrated system. }\end{array}$} & 1.3 .2 & Chapman \\
\hline$\overline{C V-5}$ & $\begin{array}{l}\text { Deploy Technology: Several improvements to the waste certification process can be realized by the } \\
\text { deployment of technology. For example, an advanced database system should track and trend information } \\
\text { facility by facility, include smart processing for consistent decision analysis (including feedback/branching } \\
\text { based on input data), and validate user input entries. Currently, WM relies on personnel to "eyeball" facility } \\
\text { data for legitimacy and consistency. Decision analysis is on a case-by-case basis. }\end{array}$ & 1.3 .2 & Chapman \\
\hline HM-1 & $\begin{array}{l}\text { Cradle-to-Grave System: Completely reengineer the "cradle-to-grave" WM process to incorporate the } \\
\text { principles of trust, teamwork, customer service, experience and expartise, "N\&S," and life-cycle cost } \\
\text { efficiency. Support and facilitate this process using best available ("off-the-shelf") information management } \\
\text { technologies linked together in such a way that waste can be tracked and managed from the point of } \\
\text { generation to final disposal using the minimum information necessary, eliminating redundant reviews and } \\
\text { approvals, and without the need to generate paper copies. }\end{array}$ & 1.3 .2 & Berry/Chapman \\
\hline$\overline{\text { RR-1 }}$ & $\begin{array}{l}\text { Seamless System: Restructure the existing waste information support systems to provide a more seamless } \\
\text { process to capture and distribute waste information. The ideal process will support the electronic capture of } \\
\text { waste information as early as possible in the life cycle of the data. Once captured the data will be routed } \\
\text { electronically from organization to organization and system to system with little to no paper involved in the } \\
\text { flow. The process will utilize existing commercially available off-the-shelf software (COTS) wherever possible } \\
\text { and will build on many of the technological infrastructure components put in place over the last } 5 \text { years } \\
\text { including networks, servers, World Wide Web support and software technologies. The process will support } \\
\text { and consolidate all waste information requirements eliminating the proliferation of redundant subsystems wilh } \\
\text { associated duplication of effort in data entry and analysis. Automation of the process will minimize manual } \\
\text { intervention. }\end{array}$ & 1.3 .2 & Chapman \\
\hline RR-2 & $\begin{array}{l}\text { Optimal GES: Identify the optimal information that waste generators must provide on the Generator Entry } \\
\text { System (GES) form set for WM to accept and complete the form set for the generator. }\end{array}$ & 1.3 .2 & Chapman \\
\hline RR-3 & $\begin{array}{l}\text { Track 90D w/GES: Utilize the existing GES to provide inventory data and track accumulallon time limits } \\
\text { remaining for 90-day accumulation areas (90-DAA) and polychlorinated biphenyl (PCB) storage areas. }\end{array}$ & 1.3 .2 & Chapman \\
\hline
\end{tabular}




\section{Core Team Recommendation \#7: Create a "Seamless" WM Information Management System (continued)}

\begin{tabular}{|c|l|c|c|}
\hline $\begin{array}{c}\text { Process Team } \\
\text { Designation }\end{array}$ & \multicolumn{1}{|c|}{ Recommendation } & Wesponsible Party \\
\hline RR-5 & $\begin{array}{l}\text { Complete Barcoding: Complete ORNL's barcoding system for electronic completion of Treatment, Storage } \\
\text { and Disposal (TSD) forms and Waste Container Record (WCR) forms. }\end{array}$ & 1.3 .2 \\
\hline RR-6 & $\begin{array}{l}\text { New Reporting Tool: Provide the existing user base with a new end-user reporting tool with more powerful } \\
\text { features and functionality. }\end{array}$ & 1.3 .2 & Chapman \\
\hline RR-7 & GES Templates: Create a set of templates for commonly generated wastes for use with the GES. & 1.3 .2 & Chapman \\
\hline RR-8 & $\begin{array}{l}\text { Electrical inspection: Implement electronic inspection record keeping/validation system for WiM storage or } \\
\text { treatment units (RCRA and Toxic Substances Control Act of 1976 [TSCA]). }\end{array}$ & 1.3 .2 \\
\hline RR-9 & Electrical PK: Include the PK form as an electronic form within GES. & 1.3 .2 & Chapman \\
\hline TF-4 & $\begin{array}{l}\text { Forecast System: Establish a "user-friendly" electronic waste and cost forecasting system that will help } \\
\text { WMO manage the program based on waste projections and will assist generators in their budgeting process } \\
\text { by providing cost projections. Table 4 lists specific suggested actions to successfully implement this overall } \\
\text { recommendation. }\end{array}$ & 1.3 .2 \\
\hline
\end{tabular}


Core Team Recommendation \#8: ORNL Should Not Convert to LMES Waste Information Tracking System (WITS)

\begin{tabular}{|c|c|c|c|}
\hline$\overline{R R-4}$ & $\begin{array}{l}\text { No WITS: Do not shift to new LMES waste tracking system (WITS); instead, continue to use existing ORNL } \\
\text { system (WTS). }\end{array}$ & 1.3 .1 & Scanlan \\
\hline
\end{tabular}




\section{Core Team Recommendation \#9: Strengthen and Emphasize the ORNL P2 Program}

\begin{tabular}{|c|c|c|c|}
\hline $\begin{array}{c}\text { Process Team } \\
\text { Designation }\end{array}$ & Recommendation & WBS & Party Responsible \\
\hline \multicolumn{2}{|c|}{$\begin{array}{l}\text { Recommendation \#9: Strengthen and emphasize the ORNL Pollution Prevention (P2) program: (1) ralse the } \\
\text { profile of the P2 program, (2) consolidate various P2 responsibilities within the P2 program, (3) implement } \\
\text { identified P2 initiatives, and (4) resurrect Chemical Stores. }\end{array}$} & 1.1 .1 & Berry' \\
\hline$\overline{\mathrm{PP}-2}$ & Cafeteria Waste: Reduce the amount of sanilary waste generated by the ORNL Cafeteria. & 1.2 .6 & $\mathrm{n} / \mathrm{a}$ \\
\hline PP-3 & Wire Disposition: Develop a simple and logical protocol for the disposition of waste electrical wiring. & 1.2 .2 & n/a \\
\hline$\overline{P P}-4$ & Central Recycable Facility: Establish a central facility for collection recyclable materials. & 1.2 .6 & Berry \\
\hline PP-5 & $\begin{array}{l}\text { Chemical Inventory: Create an active, aggressive program to reduce the current excess chemical } \\
\text { inventory and keep the future inventory as small as possible, (a) Form a "purge team", and (b) Establish } \\
\text { a Centralized Chemical Stockroom. }\end{array}$ & 1.2 .2 & Michaud \\
\hline PP-6 & $\begin{array}{l}\text { P2 Department: Evaluate the performance measures and best organizational structure and placement } \\
\text { for the Pollution Prevention Department. }\end{array}$ & 1.4 .1 & Myrick \\
\hline PP-8 & Reuse Drums: Implement a policy to reuse drums on-site or sell them to others for reuse. & 1.1 .1 & Berry \\
\hline PP-9 & $\begin{array}{l}\text { Gas Cylinders: Emphasize need for change in policies concerning gas cylinders. Used gas cylinders } \\
\text { are currenily being delivered and used in non-radioactive areas and then are found to be radioactively } \\
\text { contaminated when checked by local radiation protection personnel before return of the cylinders to the } \\
\text { vendor. These cylinders are obviously contaminated upon receipt by the user, who then becomes } \\
\text { responsible for their decontamination or disposal. This is a significant expense to the cylinder user that } \\
\text { is unfairly imposed upon them. }\end{array}$ & 1.2 .2 & Michaud \\
\hline PP-10 & $\begin{array}{l}\text { Used Oil Recycle: Develop an on-site filtration system to purify used oil or establish a recycle contract. } \\
\text { Collect and manage this stream centrally. }\end{array}$ & 1.2 .2 & Michaud \\
\hline PP-11 & $\begin{array}{l}\text { Distill Solvents: Encourage the distillation of used solvents on a laboratory scale for reuse. This must } \\
\text { first be negotiated with state regulators. }\end{array}$ & 1.2 .2 & Michaud \\
\hline PP-12 & $\begin{array}{l}\text { Material Procurement Control: Control materials procurement at the lab with an eye toward their fulure } \\
\text { disposal. }\end{array}$ & 1.1 .1 & Berry \\
\hline PP-13 & $\begin{array}{l}\text { Regulatory Advocate: Establish a strong advocate for the lab to negotiate for if and represent its needs } \\
\text { when dealing with regulators and regulatory issues that involve waste disposal, salvage, or recycling. }\end{array}$ & 1.1 .1 & Berry \\
\hline
\end{tabular}




\section{Core Team Recommendation \#9: Strengthen and Emphasize the ORNL P2 Program (continued)}

\begin{tabular}{|c|l|c|c|}
\hline $\begin{array}{c}\text { Process Team } \\
\text { Designation }\end{array}$ & \multicolumn{1}{|c|}{ Recommendation } & WBS & Party Responsible \\
\hline PP-14 & $\begin{array}{l}\text { Construct Recycling Responsibility: Establish conformily and continuity in recycling programs. } \\
\text { Implement all recycling contracts via the P2 Department. Disseminate information on all recycling } \\
\text { programs. Make collection bins for recyclables plentiful and convenient and empty them often. }\end{array}$ & 1.1 .1 \\
\hline PP-15 & $\begin{array}{l}\text { Generator Cost Saving: Make generators aware that they are going to be charged for WM services in } \\
\text { the future. }\end{array}$ & 1.1 .1 & Berry \\
\hline PP-17 & $\begin{array}{l}\text { Retiree Labs: Establish laboratory policy to prevent personnel from retiring or leaving the lab without } \\
\text { first arranging for the disposition of their chemical inventory (and legacy waste). }\end{array}$ & 1.2 .2 & Michaud \\
\hline PP-18 & $\begin{array}{l}\text { Eliminate Existing Chargeback: The current P2 chargeback tax program should be eliminated } \\
\text { because: (a) It costs a great deal of money (approximately 33\% of the revenue generated) to collect the } \\
\text { tax to cover accounting costs, etc., and (b) Charge numbers for collecting the tax are frequently invalid } \\
\text { due to the lag time between project conclusion and waste disposal. } \\
\cdot\end{array}$ & 1.2 .6 \\
\hline
\end{tabular}




\section{Core Team Recommendation \#10: Improve WM Operating Cost Efficiencies}

\begin{tabular}{|c|c|c|c|}
\hline $\begin{array}{c}\text { Process Team } \\
\text { Designation }\end{array}$ & Recommendation & WBS & $\begin{array}{l}\text { Responsible } \\
\text { Party }\end{array}$ \\
\hline \multicolumn{2}{|c|}{$\begin{array}{l}\text { Recommendation \#10: Improve WM operating cost efficiencies: (1) initiate discussions with the Bargaining Unit to } \\
\text { take full advantage of the broadened craft work categories provided for in the current contract, (2) assign dedicated } \\
\text { maintenance personnel to Waste Management and Remedial Action Division (WMRAD) to reduce need for backups } \\
\text { and additional training, and (3) endorse and support the ORNL evaluation of reduced overhead rates charged to } \\
\text { service organizations to be more representative of the burden associated with this type of waste organization in the } \\
\text { commercial world. }\end{array}$} & 1.1 .1 & Berry \\
\hline$\overline{C T-1}$ & $\begin{array}{l}\text { Reduce Overhead for Service Organizations: ORNL should charge a lower overhead rate to those service } \\
\text { organizations that are program funded. }\end{array}$ & 1.1 .1 & Berry \\
\hline TS-2 & $\begin{array}{l}\text { Bargaining Unit Maintenance Craft Work Agreement: Negotiate with the Bargaining Unit to include all hourly } \\
\text { pay codes in the existing maintenance craft work agreement. }\end{array}$ & 1.1 .1 & Berry \\
\hline TS-9 & $\begin{array}{l}\text { Liquid Gaseous Waste Operations (LGWO) Maintenance Staff: Assign "dedicated" staff to LGWO Section to } \\
\text { perform routine and special maintenance tasks. }\end{array}$ & 1.1 .1 & Berry \\
\hline
\end{tabular}


Core Team Recommendation \#11: Eliminate Policy Mixed Waste Through Effective Implementation of the No-Rad Added Policy

\begin{tabular}{|c|c|c|c|}
\hline $\begin{array}{c}\text { Process Team } \\
\text { Designation }\end{array}$ & Recommendation & WBS & $\begin{array}{c}\text { Responsible } \\
\text { Party }\end{array}$ \\
\hline \multicolumn{2}{|c|}{$\begin{array}{l}\text { Recommendation \#11: Eliminate "pollcy mixed waste" through effective implementation of the No-Rad Added } \\
\text { policy: (1) eliminate fear of individual liability/recrimination, (2) implement ORNL off-site approval process (no } \\
\text { LMES review), and (3) update and maintain Radioactive Material Management Area (RMMA) database to function } \\
\text { as a convenient "no-rad added" verification tool. }\end{array}$} & 1.2 .2 & $\begin{array}{l}\text { Waste } \\
\text { Cooordinälión } \\
\text { Team }\end{array}$ \\
\hline$\overline{C V-7}$ & $\begin{array}{l}\text { Respond to Needs of No-Rad Added: The quantity of hazardous material currently under the control of } \\
\text { waste generators is large. Waste generated from the use of this material, particularly when it originates from } \\
\text { within an RMMA, has the potential to be contaminated with radioactive material. The existing ORNL } \\
\text { infrastructure, support, and guidance for delineating No-Rad Added under these conditions is NOT } \\
\text { responsive to the generator's needs. A program needs to be established to respond to this significant need. }\end{array}$ & 1.2 .2 & $\begin{array}{l}\text { Waste } \\
\text { Coordination } \\
\text { Team }\end{array}$ \\
\hline HM-2 & $\begin{array}{l}\text { Off-Site Approval.: The approval for shipping waste to off-site facilities is to be streamlined to minimize } \\
\text { duplicative reviews and delays in executing shipments. The Director of WM shall be authorized to approve } \\
\text { waste or waste stream shipments to off-site facilities verifying appropriate certifications are completed and } \\
\text { requirements at the receiving facility are met. }\end{array}$ & 1.2 .2 & $\begin{array}{l}\text { Waste } \\
\text { Coordination } \\
\text { Team }\end{array}$ \\
\hline HM-4 & $\begin{array}{l}\text { RMMA Database: Update and maintain the health physics database on current posting of RMMAs to serve } \\
\text { as a historical record and status of the RMMAs at ORNL. Allocate adequate resources to maintain the } \\
\text { database. }\end{array}$ & 1.2 .2 & $\begin{array}{l}\text { Waste } \\
\text { Coordination } \\
\text { Team }\end{array}$ \\
\hline TS-6 & No-Rad Added: Accelerate and expand generator implementation of No-Rad Added Program. & 1.2 .2 & $\begin{array}{c}\text { Waste } \\
\text { Coordination } \\
\text { Team }\end{array}$ \\
\hline
\end{tabular}




\section{Core Team Recommendation \#12: Replace the Function of the PWTP}

\begin{tabular}{|c|c|c|c|}
\hline $\begin{array}{c}\text { Process Team } \\
\text { Designation }\end{array}$ & Recommendation & WBS & $\begin{array}{c}\text { Party } \\
\text { Responsible }\end{array}$ \\
\hline \multicolumn{2}{|c|}{$\begin{array}{l}\text { Recommendation \#12: Replace the function of the Process Waste Treatment Plant (PWTP) with more efficient } \\
\text { technology and integrate it into the Non-Radiological Wastewater Treatment Plant (NRWTP) operations: (1) utilize new } \\
\text { technology to eliminate/reduce LLLW generation from regeneration of current lon exchange columns, and (2) privatize the } \\
\text { financing, design, and construction of the.new system, with operations integrated into the NRWTP. }\end{array}$} & 1.2 .4 & Dean \\
\hline PP-7 & $\begin{array}{l}\text { lon-Exchange PWTP: Emphasize and expedite research on improved methods of ion-exchange column } \\
\text { regeneration at the PWTP to decouple the process waste system from the LLLW system and therefore eliminate the } \\
\text { largest LLLW flow into the system. }\end{array}$ & 1.2 .4 & $n / a$ \\
\hline TS-1 & $\begin{array}{l}\text { Ion-Exchange PWTP: Pending success of FY } 1997 \text { pilot scale studies being conducted by Chemical Technology } \\
\text { Division, replace the PWTP - Bullding } 3544 \text { with an electrochemical ion-exchange unit operation to be added at the } \\
\text { NRWTP - Bullding 3608. Pursue co-funding from EM-50 Technology Implementation Initiative and EM-30 WM. }\end{array}$ & 1.2 .4 & $n / a$ \\
\hline
\end{tabular}




\section{Core Team Recommendation \#13: Eliminate Excess Conservatism in Operations Requirement Documents}

\begin{tabular}{|c|c|c|c|}
\hline $\begin{array}{c}\text { Process Team } \\
\text { Designation }\end{array}$ & Recommendation & WBS & $\begin{array}{c}\text { Party } \\
\text { Responsible }\end{array}$ \\
\hline HM-FA-1 & N\&S Permits: Eliminate excess requirements in RCRA permils. & 1.2 .5 & Daugherty \\
\hline TS-7 & $\begin{array}{l}\text { Graded COO: Implement graded COO. Train to DOE Order } 5480.20 \text { A requirements at WMRAD Nuclear Facilities } \\
\text { only. }\end{array}$ & 1.2 .5 & Daugherty \\
\hline WC-5 & $\begin{array}{l}\text { On-Site DOT: Use standard radiological protection procedures - not DOT requirements -- to move materials on-site. } \\
\text { Revise the On-Site Transportation Plan for ORNL. }\end{array}$ & 1.2 .5 & Daugherty \\
\hline
\end{tabular}


Core Team Recommendation \#14: Improve Communications with and Accountability of Subcontractors

\begin{tabular}{|c|c|c|c|}
\hline $\begin{array}{l}\text { Process Team } \\
\text { Designation }\end{array}$ & Recommendation & Responsible \\
Party & WBS \\
\hline $\begin{array}{l}\text { Recommendation \#14: Improve oversight and control of on-site subcontractors that generate waste to ensure } \\
\text { appropriate WM under terms of their contracts, thus eliminating "Orphaned" waste. This can be accomplished through: } \\
\text { (1) involvement of Engineering and Environmental Restoration Project Managers on WM Customer Advisory Panel, } \\
\text { (2) strengthening subcontract language/penalties with regards to WM requirements, and (3) establishing ties to new } \\
\text { M\&l contractor and other DOE primes such that communication about WM issues is facilitated. }\end{array}$ & 1.1 .3 \\
\hline DE-9 & $\begin{array}{l}\text { Mel Stakeholder: ORNL staff need to be involved in DOE-OR Operations/EM activities that could compromise } \\
\text { our mission: Comprehensive Environmental Response, Compensalion, and Liability Act of 1980 (CERCLA) } \\
\text { stakeholder - About half the team endorsed "owning" the most critical problems. }\end{array}$ & 1.1 .3 \\
\hline TF-5 & $\begin{array}{l}\text { Subcontractor Communication: Improve communication of WM requirements to and the accountability of } \\
\text { subcontractors. Table 5 lists specific suggested actions to successfully implement this overall recommendation. }\end{array}$ & 1.1 .3 & Berry \\
\hline
\end{tabular}




\section{Core Team Recommendation \#15: Re-examine WMRAD Organization in Light of Reengineering Recommendations}

\begin{tabular}{|l|l|l|}
\hline $\begin{array}{l}\text { Process Team } \\
\text { Designation }\end{array}$ & Recommendation & Responsible \\
Party
\end{tabular}


Process Team Recommendations Not Represented in Core Team Roll-Up

\begin{tabular}{|c|c|c|}
\hline $\begin{array}{l}\text { Process Team } \\
\text { Designation }\end{array}$ & Recommendation & WBS \\
\hline CV-8 & $\begin{array}{l}\text { Act Soon: Waste certificalion reengineering is urgent: changing international transportation regulations will impact certification; } \\
\text { a much larger fraction of waste will likely be shipped off-site in the near future (more impetus to perform to higher receiving } \\
\text { facility standards/plus business risk of miscertifying containers that will then be in another state and facility); and finally, the } \\
\text { rebidding of one of the contracts in the Oak Ridge WM consortium requires that ORNL pay attention to decisions being made in } \\
\text { preparation for that contract, including waste funding prioritites and paths, and ownership of waste located at ORNL and } \\
\text { elsewhere. As a result of ensuing change, we recommend that the laboratory appoint personnel to keep abreast of the } \\
\text { reengineering subtasks, to assure that the integration of these subtasks is efficient and timely. An individual with a } \\
\text { process/systems engineering background would be optimum. }\end{array}$ & 1.5 \\
\hline$\overline{\mathrm{DE}-5}$ & $\begin{array}{l}\text { Transfer Legacy To M\&l: Immediate activilies should focus on maximizing the amount of legacy material transferred to DOE- } \\
\text { OR Operations/EM - Written agreements with DOE-OR Operalions/EM on what will be transferred when? }\end{array}$ & 1.5 \\
\hline HM-3 & $\begin{array}{l}\text { LMES-LMER Transition: Accelerate the LMES-to-LMER transition of WM facilities and funding necessary for ORNL to } \\
\text { independently manage NG waste, including: (a) Transfer legacy mixed waste to ETTP (formerly K-25 Site) as expeditiously as } \\
\text { possible, ideally prior to the awarding of the EM M\&I contract in March 1998. To accomplish this, the process for which waste } \\
\text { is shipped to ETTP must be streamlined, (b) Transfer legacy hazardous waste (waste that presently does not have a "no-rad- } \\
\text { added" approval) to off-site trealment or ETTP as expeditiously as possible, (c) Develop an MOU and schedule for the } \\
\text { transition of NG facilities to LMER, and (d) Close all Legacy Waste facilities emptied by transfer to ETTP or off-site treatment. }\end{array}$ & 1.5 \\
\hline HM-5 & $\begin{array}{l}\text { 2109 } 10 \text { Days: Operators of 90-Day Areas should turn in completed } 2109 \mathrm{~s} \text { within } 10 \text { calender days of placing the waste in that } \\
\text { area. This time frame will allow for the flexibility to ship off-site directly from large quantity } 90 \text {-day areas. It will also eliminate } \\
\text { duplication of work for waste items not fully classified due to the waste forms not being completed and received in a time frame } \\
\text { to allow required steps for pickup. If there are extenuating circumstances that prevent submiltal of the forms within } 10 \text { days, a } \\
\text { plan of actions should be worked out beforehand with agreement of the generator and WM. The generator will be accountable } \\
\text { for any additional costs and regulatory noncompliances caused by submittal of } 2109 \text { s later than } 10 \text { days. }\end{array}$ & 1.5 \\
\hline HM-FA-3 & $\begin{array}{l}\text { Make-or-Buy: Conduct make-or-buy analyses to delermine the viability of outsourcing discrete elements or the totalify of the } \\
\text { hazardous/mixed waste management process. }\end{array}$ & 1.5 \\
\hline TS-3 & $\begin{array}{l}\text { No Batch Treatment: Maintain continuous "around-the-clock" operations at the Process Waste Treatment Complex rather } \\
\text { than implement "batch treatment". }\end{array}$ & 1.5 \\
\hline
\end{tabular}




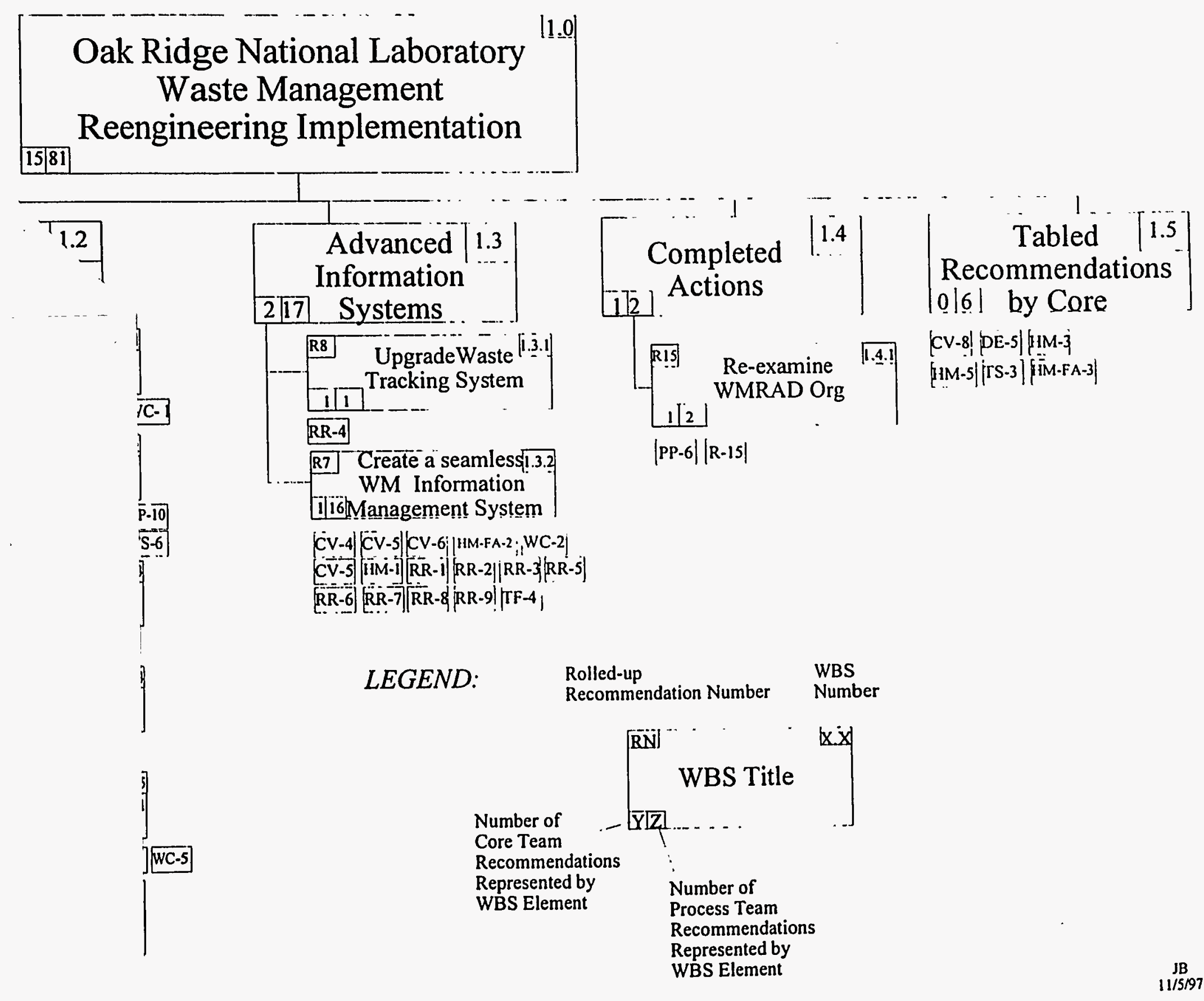


APPENDIX B

WASTE MANAGEMENT REENGINEERING

WORK BREAKDOWN STRUCTURE 


\section{SUMMARY OF WASTE MANAGEMENT REENGINEERING IMPLEMENTATION WORK BREAKDOWN STRUCTURE (WBS)}

The list below summarizes the tasks and subtasks for each of the three main elements of the WBS. Full text describing the tasks and subtasks follows the list.

\subsection{Best Business Practices}

Task

1.1.1 Waste Management Reengineering Business Strategy and Approach Subtask

1.1.1.1 Establish Business Strategy and Approach

1.1.1.2 Implement Business Strategy and Approach

Task

1.1.2 Commercial Practices

Subtask

1.1.2.1 ORNL as a Single Generator

1.1.2.2 Advocate of Endpoint Availability and Pollution Prevention

1.1.2.3 Off-site Waste Shipment

1.1.2.4 Improve Cost-Effectiveness of Waste Management

Task

1.1.3 Communications

Subtask

1.1.3.1 Improve Teaming Between the ORNL Waste Generator and WMRAD

1.1.3.2 Adopt a Proactive Approach to Communications with DOE

1.1.3.3 Improve Communications and Accountability of Subcontractors

\subsection{Process Reengineering}

Task

1.2.1 Perform Systems Analysis

Subtask

1.2.1.1 Process Mapping and Systems Analysis Management

1.2.1.2 Information Support for Analyses, Planning, and Tracking

1.2.1.3 Conduct Targeted Analyses of ORNL Systems to Support EM-30 Planning and Reengineering Implementation

Task

1.2.2 Reengineer Waste Coordination

Subtask

1.2.2.1 Waste Certification Program Implementation

1.2.2.2 Generator Interface Program

1.2.2.3 No-rad-added Program

1.2.2.4 Pollution Prevention Program

Task

1.2.3 Reengineer Solid Low-Level Waste Process 


\section{Subtask}

1.2.3.1 Develop Process Activity Logic Diagrams

1.2.3.2 Planning Solid Low-Level Waste Reengineering

1.2.3.3 Segregate Solid Low-Level Waste from Industrial/Sanitary Waste for Treatment

1.2.3.4 Analyze Cost/Benefit to Guide Implementation

1.2.3.5 Institute Store for Decay Program

Task

1.2.4 Reengineer Process Waste Treatment Plant

Subtask

1.2.4.1 Evaluate Process Improvements

1.2.4.2 Develop Procurement Strategy

1.2.4.3 Implement Technology

1.2.4.4 Update Records to Reflect Improvements

1.2.4.5 Shut Down Process Waste Treatment Plant

Task

1.2.5 Requirements Evaluation and Elimination

Subtask

1.2.5.1 Eliminate On-site Department of Transportation Equivalency

1.2.5.2 Negotiate "Above-and-Beyond" Requirements from RCRA Permits

1.2.5.3 Apply Necessary and Sufficient Process

1.2.5.4 Implement Graded Approach to Waste Management Conduct of Operations

Task

1.2.6 Ship Mixed Waste to East Tennessee Technology Park

\section{Subtask}

1.2.6.1 Remove Barriers

1.2.6.2 Accelerate Shipments

Task

1.2.7 Future Endeavors

Subtask

1.2.7.1 Use Bldg. 3517 and 3525 for Waste Treatment

1.2.7.2 Evaluate Expanded use of $Y-12$ Landfill

\subsection{Advanced Information Management Systems}

Task

1.3.1 Upgrade Waste Tracking System

Task

1.3.2 Create a Seamless Waste Information Management System

\section{Subtask}

1.3.2.1 Develop Data Quality Objectives Covering Characterization and Waste Form

1.3.2.2 Deploy Technology to the Waste Certification Process

1.3.2.3 Provide Information Management Tools and Forms 


\section{APPENDIX B}

\section{WASTE MANAGEMENT REENGINEERING WORK BREAKDOWN STRUCTURE}

\section{WBS 1.1 BEST BUSINESS PRACTICES}

\section{Task 1.1.1 Waste Management Reengineering (WMRE) Business Strategy and Approach}

Task Description: The objective of this task is to establish a business strategy and approach for reengineering waste management (WM) at ORNL to support future growth while providing guidelines to streamline WM processes. This will result in Waste Management and Remedial Action Division (WMRAD) becoming a more competitive supplier of WM services. Costs for WM activities will be reduced and capacity for additional work will be increased while full compliance will be maintained. To accomplish these objectives, incentives for cost reduction must be understood and used to motivate institutional change. This task will develop a business strategy that is predicated on a performance-based incentive structure for WM. The business strategy will be used to support policy decisions on appropriate overhead rate(s) for WMRAD and methods to compel generators to reduce waste generation by using WM services and implementing pollution prevention (P2). The cost-effectiveness of reengineering measures must be understood through quantitative assessment of performance metrics.

\section{Resources}

ORNL overhead (OH) Cost to Implement: $\$ 170 \mathrm{~K}$

Sources of Funding: WMRE/WMRAD

\section{Subtask 1.1.1.1 Establish Business Strategy and Approach}

Subtask Description: This subtask will provide a framework for business decisions and motivate more cost-effective practices by creating and defining incentives that will compel:

1. WMRAD to streamline waste processing activities resulting in reduced cost and increased capacity;

2. Waste generators to reduce the volume of waste generated through P2 and improved work practices;

3. Researchers to reduce the time that they spend on WM activities; and

4. Management of increased volumes of legacy waste using capacity made available by (1) and (2).

This business strategy will protect ORNL's present and future interests in newly generated waste and define growth strategies. These growth strategies will improve the competitive position of researchers and retain management of legacy waste through subcontracts with the new Management and Integration (M\&I) contractor. The action plan will relate the overhead rate, WM charges imposed on researchers, and strategies for growth. To streamline WM work practices, incentives for accepting risk associated with more cost-effective practices will be evaluated and plans for encouraging responsible acceptance of performance risk will be identified. The WMRE Business Strategy and Approach Action Plan will establish the basis for field work proposal (FWP) guidance on WM funds required for Energy Research projects. 


\title{
Subtask Schedule and Deliverables
}

\author{
Milestone:
}

- Brief DOE on the WMRE initiative by October 1997.

- Develop incentives and performance metrics by December 1997.

- Customer Advisory Panel approves incentives by January 1998.

- FWP guidance for 2000.

\section{Deliverables:}

- Action plan for implementing business strategy and approach that is founded on performance-based incentive structure. November 1997.

- Management concurrence with action plan for implementing incentive structure including FWP guidance. December 1997.

\section{Subtask 1.1.1.2 Implement Business Strategy and Approach}

Subtask Description: In order for WMRAD to remain a viable organization in the face of increasing competition and budget reductions, ORNL must recognize WM as an important service critical to mission success with potentially "showstopping" ramifications. The culture within WMRAD must change by instilling a customer-service attitude and approach to doing business. Similarly, researchers must recognize that more cost-effective methods of managing waste as it is generated will result in ORNL becoming a more competitive research institution. The "cradle-to-grave" WM process must be completely reengineered to incorporate the principles of trust, teamwork, customer service, experience and expertise, "necessary and sufficient (N\&S)" and life-cycle cost efficiency through responsible acceptance of performance risk. Improvements in the effective utilization of human resources and job enrichment must also be pursued.

Incentives identified in the business strategy will be implemented to compel ORNL to adopt more costeffective WM practices. Cultural change will occur by the communication of the management-approved incentives that fundamentally change the reward structure for WM work practices. These incentives must be understood and realized by those who are completing WM, including craft and chemical operator, and research tasks. The basic reward will be that more individuals may be able to retain employment at ORNL if growth opportunities are seized.

Reengineering the Solid Low-Level Waste (SLLW) process will include both process modification and better coordination of waste receipt from generators. Actives include P2 through improved work practices, improved and streamlined characterization, segregation of radioactive and non-radioactive waste to dramatically reduce SLLW volume, and streamlining access to disposal endpoints. The imminent closure of Interim Waste Management Facility (IWMF) provides a driving force for these changes. This example provides a basis for reducing researcher time spent on WM activities and for reducing the volume of waste generated through P2 and improved work practices.

Reengineering the Process Waste Treatment Plant (PWTP) provides a high-payback activity for WMRAD/ORNL to accept performance risk. WMRAD is the largest generator of SLLW due to the filter cake produced at the PWTP. If incentives for accepting responsible performance risk were in place, this waste could potentially be shipped to disposal rather than stored. Further, awarding a subcontract for performance based removal of radionuclides from process waste water will require managers to accept risk and modification of work practices. Incentives for change must be in place to compel managers and field personnel to change to these more cost-effective methods. 
This subtask will implement incentives to encourage behavior that will be more cost-effective and will communicate with field personnel regarding new incentives. In this way, WMRAD can remain viable in an increasingly competitive and cost conscience environment through a change in its organizational culture that is enforced through incentives. This change must begin at the top with senior management and effect the entire organization. This subtask provides support for the facilitation of a process to assist representatives of ORNL maniagement, WMRAD, and waste generators in internalizing new incentives. Using reengineering of the SLLW and PWTP processes as examples, implementation will include reviewing the WMRAD mission, values, purpose, structure and relationships; establishing ORNL management, WMRAD personnel, and waste generator expectations of WMRAD; assessing current conditions relative to expectations; identifying issues regarding the incentive structure; setting priorities for issue resolution; and working toward issue resolution. If incentives for change are not in place, the probability is low that reengineering initiatives will succeed.

\section{Subtask Schedule and Deliverables}

Milestone:

- Incentives implemented and communicated to researchers, generators, WMRAD.

Deliverables:

- Plan to implement, communicate and continually improve incentive structure. January 1998.

- WMRE report on results using performance metrics and communication. September 1998.

\section{Task 1.1.2 Commercial Practices}

Task Description: ORNL must adopt commercial WM practices in order to be competitive with worldclass research and development institutions. Efficiency gains can be realized by recognizing ORNL as a single waste generator rather than 1500 individual generators required to certify waste for disposal. By minimizing the number of individually managed waste streams, significantly lower costs for waste verification and certification can be achieved. Senior ORNL management will advocate negotiations with regulators on issues involving disposal, salvage, or recycling. Greater efficiency and cost-effectiveness can be realized through more active endpoint management by ensuring endpoint availability and thus reducing storage cost, pursuing waivers to waste acceptance criteria (WAC) at potential disposal sites, collaborating with other National Laboratories for access to key endpoints, and recognizing and managing state equity balance. Streamlining the approval process for shipping wastes to off-site facilities is needed to minimize duplicate reviews and delays in executing shipments. Savings can be realized in both labor hours and storage costs.

\section{Resources}

ORNL OH Cost to Implement: $\$ 10 \mathrm{~K}$

Sources of Funding: WMRE/WMRAD

\section{Subtask 1.1.2.1 ORNL as a Single Generator}

Subtask Description: This subtask provides focus and support for the Process Reengineering efforts that will enable ORNL to become a single generator, with research organizations being the customer of the a WM service organization. This approach enables the laboratory to consolidate what are today considered individual waste streams into broader "ORNL waste streams" that can then be certified by the laboratory prior to disposal. The best available commercial practices will be modeled to optimize 
the efficiency and cost-effectiveness of WM activities at ORNL. Reengineering Waste Coordination (Task 1.2.2) will result in increased generator awareness of $P 2$ as a means of reducing costs and will improve interfaces with generators. Management support for instilling commercial practices such as recognizing waste generators as customers, focusing on customer service, and support for teaming opportunities to optimize efficiency in WM processes will be coordinated with the WMRE Business Strategy and Approach.

\section{Subtask Schedule and Deliverables}

Milestone:

- Management support for Reengineering Waste Coordination.

\section{Subtask 1.1.2.2 Advocate Endpoint Availability and P2}

Subtask Description: Senior ORNL management will advocate improvements to WM processes to ensure disposal endpoints are available and to institute P2. Senior management will negotiate with regulators on issues such as disposal, salvage, and recycling. WBS 1.2.1 Perform Systems Analysis will provide expert consultation to define strategies that will ensure disposal endpoint availability, pursue WAC waivers, collaborate with other National Laboratories for access to key endpoints, and adopt free release standards. Senior ORNL management will, then, review and approve these strategies and actively negotiate regulatory and state equity issues.

\section{Subtask Schedule and Deliverables}

Milestone:

- Management advocacy for disposal endpoints.

\section{Subtask 1.1.2.3 Off-Site Waste Shipment}

Subtask Description: The approval for shipping waste to off-site facilities is to be streamlined to eliminate duplicate reviews and delays in executing shipments. Once ORNL direct contracts with offsite disposal facilities are in place, the Waste Certification Official will be authorized to approve waste or waste stream shipments to off-site facilities verifying appropriate certifications are completed and requirements at the receiving facility are met.

\section{Subtask Schedule and Deliverables}

Deliverables:

- LMER contracts for SLLW and/or MLLW with off-site facilities by April 1998.

\section{Subtask 1.1.2.4 Improve Cost-effectiveness of WM}

Subtask Description: Improve cost-effectiveness of the Liquid and Gaseous Waste Operations (LGWO) through improved labor working relationships. Assign "dedicated" craft to LGWO Section to perform routine and special maintenance tasks. Use teams of skilled craftsmen to complete assignments. By the 2001 labor contract negotiation, evaluate whether re-negotiation of the labor agreement to include chemical operators in the existing maintenance craft work agreement would be cost-effective. 
Reduce unnecessary waste generated by cafeteria operations. Draft specific contract language for each recycling contract and ensure coordination with Procurement.

\section{Subtask Schedule and Deliverables}

Deliverables:

- Revise craft support of Liquid, Gaseous Waste Operating Group by March 1998.

\section{Task 1.1.3 Communications}

Task Description: The purpose of this task is to improve WMRAD communications, both internally with waste generators and project managers, and externally with DOE and the M\&I contractor. The specific objective is for WMRAD communications to be more generator-friendly while describing and implementing the incentive structure for generators to change work practices. Work practices will continue to be safe and compliant for newly generated wastes, recyclables, and legacy waste. Senior ORNL and WMRAD management will lead customer-oriented communications through participation on the Customer Advisory Panel. Senior management involvement in review and approval of cost-effective changes will provide a basis for communications with the M\&I contractor regarding ORNL WM services.

\section{Resources}

ORNL OH Cost to Implement: $\$ 75 \mathrm{~K}$

Sources of Funding: WMRE/WMRAD

\section{Subtask 1.1.3.1 Improve Teaming Between the ORNL Waste Generator and WMRAD}

Subtask Description: Promote cooperation and teamwork by improving internal communications and teaming opportunities between the generator/customer and the WM organization. The WM organization must focus on their core mission: manage the generator/customer's waste in a compliant, timely, and cost-effective manner with minimal disruption to the generator/customer. Generators must understand that their input to the process is critical to its ultimate success. Both WM and generators must recognize that if we can not accomplish this mission through cooperation, there are competitors who believe they can. The specific goal is to continue and expand the effectiveness of the Generator Interface Group to identify additional improvements in the interface between ORNL and WMRAD which ensure an attitude of customer service and cost efficiency.

\section{Subtask Schedule and Deliverables}

Milestone:

- Team generators and WM through Customer Advisory Panel.

Deliverables:

- Performance Metrics for Improved Communications. March 1998. 


\section{Subtask 1.1.3.2 Adopt a Proactive Approach to Communications with DOE}

Subtask Description: Senior ORNL management will support a change in Lockheed Martin corporate approach to communications with its DOE customers to be proactive not reactive, to reflect its perspective that $\mathrm{DOE}$ is a single customer even though there are multiple factions within that customer, and to reflect its ability to please multiple and diverse customers (DOE and non-DOE) by developing "win-win" solutions that help achieve overall program cost efficiencies to benefit all customers.

\section{Subtask Schedule and Deliverables}

Milestones:

- Lockheed Martin management support for proactive approach with DOE.

Deliverables:

- Senior Lockheed Martin representation on the Customer Advisory Panel.

\section{Subtask 1.1.3.3 Improve Communications and Accountability of Subcontractors}

Subtask Description: Projected increases in subcontractor activities at ORNL has created potential vulnerabilities with regard to WM. A number of subcontractors have left their job sites without fulfilling their contract requirements on WM. Examples have been cited in which the contract did not include the correct requirements for WM. In each example, the additional cost and burden was placed on the ORNL "generator organization." The uncontrolled generation of construction debris creates the potential for these costs and burdens to increase as subcontractor activity increases. In order to improve communication of WM requirements and accountability of subcontractors, ORNL's WMRE will develop revised subcontractor language to strengthen enforcement of WM requirements. EM\&EF project management will participate in developing the revised subcontract language while construction project managers/project engineers will be responsible for implementing the revision. The effectiveness of this approach will be tracked by monitoring the type and amount of waste generated during construction projects.

\section{Subtask Schedule and Deliverables}

Milestones:

- EM\&EF participation on the Customer Advisory Panel to facilitate implementation of modified subcontract terms and conditions. October 1997.

Deliverables:

- Contract language modifications to place responsibility for WM on contractors including waste reduction and recycling language included in contract language. April 1998.

- Revised procedures for construction and environmental restoration project engineers. July 1998.

- Performance metrics for tracking compliance with WM subcontract requirements and subcontractor accountability. September 1998. 


\section{WBS 1.2 PROCESS REENGINEERING}

\section{Task 1.2.1 Perform Systems Analysis}

Task Description: Perform a comprehensive systems analysis as the basis for WM strategic planning (WM Reengineering Recommendation \# 3). Evaluate current and future waste streams and generation rates. Identify optimal management approaches (e.g., reduction/elimination, operational changes, new or upgraded facilities, outsourcing) with consideration of life-cycle costs. Full implementation of many of the 15 WM Reengineering recommendations (Myrick 1997) is linked to the systems analysis. Estimated priority for, implementability of, and cost savings from the systems analysis were all high.

\section{Resources}

ORNL OH Cost to Implement: $\$ 250 \mathrm{~K}$

Sources of Funding: WMRE; WMRAD funds for (1) waste forecasting, and (2) contingency planning for expected loss of the disposal capacity in the IWMF at the end of FY 1998.

\section{Subtask 1.2.1.1 Process Mapping and Systems Analysis Management}

Subtask Description: This Subtask provides oversight, technical direction, and management of the overall systems analysis effort. Process activity logic diagrams will be developed and used to guide implementation of process improvements.

Subtask background. Although it is recognized that the Laboratory needs to perform a systems analysis on its waste generating and management activities to determine the optimum approach for each waste stream, covering the range from generation to ultimate disposal, and for the WM enterprise in its entirety, the WM Reengineering effort was actually the first phase of this effort. Thus, the directions and priorities provided by the WM Reengineering Core Team in its Final Report (ORNL/TM-13488) are an excellent starting point. To build on the foundation of this report, the processes that are being reengineered must be clarified. This high-level structure will allow analysis of the affect of changing one process activity on other process activities. Process activity logic diagrams will be documented for the major WM processes: Solid Waste and Liquid Waste.

Linkage to WBS 1.2.3 SLLW Reengineering and WBS 1.2.4 Reengineer the.PWTP. The report recommends that WM be endpoint-focused, and that the analysis focus initially on the generating steps and the disposal endpoints associated with solid radioactive wastes (Subteam Recommendation WC-1). Discussions with primary customers reinforced the need to support reengineering of the solid LLW management process (Subtask 1.2.3) as the highest priority. Accomplishing the latter will also require a focus on and strengthening of $\mathrm{P} 2$ and a consistent, verified, and validated approach to radioactive waste characterization and certification (Subtask 1.2.2). The need has been intensified by the projected loss of on-site disposal capabilities at the IWMF in FY 1999 because of budget restrictions.

Liquid Waste Process Reengineering. It is currently expected that assessments of the liquid waste systems will be deferred until later in FY 1998 or until FY 1999 (most likely case because of projected resource limitations). However, the extent to which an analysis of the liquid waste systems can be deferred is subject to the level of success encountered in replacing the Process Waste Treatment Plant (PWTP)(Subtask 1.2.4: Reengineer the PWTP). If difficulties are encountered early on with either procurement or technology development for the PWTP, it will be necessary to revisit these initial priorities. 
Transuranic (TRU) Waste Process Reengineering. A decision on the level of effort to be devoted to TRU wastes will be deferred pending information from the DOE on (1) early procurement activities for the ORNL TRU Waste Processing Facility and (2) the projected opening of the Waste Isolation Pilot Plant in FY 1998. (Much of what is now considered solid TRU waste will have to be covered in analyses for LLW because of uncertainties in characterization.)

\section{Subtask Schedule}

Deliverables:

- Complete process maps including approaches/tools for tracking process improvements for use in WM reengineering implementation by December 1997.

\section{Subtask 1.2.1.2 Information Support for Analyses, Planning, and Tracking}

Subtask Description: A catalogue of waste streams, their major characteristics (including the rationale for generation), and projected changes will be compiled to determine the potential for (1) elimination or reduction, (2) aggregation (i.e., combine similar materials together), (3) volume reduction and need for other treatment, and (4) matching with a particular endpoint. Compilation and evaluation of existing data on ORNL wastes (sources, rates, matrices, hazardous/radiological characteristics, etc.), along with development of projections of future generation, is thus a critical need for use in systems analyses. The activities in this Subtask will result in forecasting of ORNL waste streams. This Subtask will link with EM\&EF waste and cost forecasting system.

FY 1998 activities will focus most heavily on evaluation of information on sources and characteristics of SLLW and mixed wastes. Depending on budget availability and feedback on progress in Subtask 1.2.4 (Reengineer the PWTP), updating and assessment of information on sources of liquid LLW will be carried out in early FY 1999, along with development of similar information for the process waste systems.

\section{Subtask Schedule}

Milestones:

- Complete evaluation of existing solid waste data by December 31,1997 .

- Complete surveys and interviews to fill in major gaps and obtain waste forecasts from major generators by March 31, 1998.

- Complete evaluation of existing liquid waste data, including surveys and interviews with waste generators to fill in major gaps and obtain waste forecasts, by December 31, 1998.

Deliverables:

- Report on major findings and data needs for solid LLW and mixed wastes by April 30, 1998.

- Report on major findings and data needs for liquid waste systems by January 31, 1999.

Subtask 1.2.1.3 Conduct Targeted Analyses of ORNL Systems to Support EM-30 Planning and Reengineering Implementation

Subtask Description: Systems analysis activities will proceed in a stepwise fashion, with each succeeding iteration able to handle more and better information as it becomes available, expanding the analysis to include more of the process activities. Process maps or logic diagrams covering the significant components of waste generation and management, emphasizing those aspects that will be 
the focus of reengineering, will first be evaluated to provide a "sanity check" on the overall direction of the implementation process. Succeeding activities will be focused where information is both comprehensive and readily available. This will most likely involve analysis of well-defined, discrete processes or steps to support needs identified by the EM-30 manager in the OEMP as supported by reengineering implementation. Priorities and team composition for application of systems analyses are being established with the understanding and agreement of the Reengineering Implementation Manager, the EM-30 manager reporting to the OEMP, the WMRAD Division Director, and the OEMP Manager. These priorities will also be reviewed by the Core Team.

FY 1998 activities will focus most heavily on analysis of information on sources and characteristics of SLLW and mixed wastes in relation to Data Quality Objectives (DQOs). Within this effort, one of the highest priorities will be to (1) determine whether the large volumes of uncontaminated materials now treated as LLW can be segregated effectively, and (2) examine the potential for aggregating much of the remainder to reduce the number of radioactive waste streams that have to be characterized and treated to gain access to the projected disposal endpoints. The level of effort devoted to optimize the intermediate steps in SLLW management will be subject to the availability of both suitable information and funding in FY 1998.

In FY 1999, the focus of the analysis for SLLW and mixed wastes will be on (1) why such waste streams are being generated to support analyses of the potential for their reduction or elimination and (2) more intensive analyses of the intermediate management activities (from characterization through packaging for disposal). Intensive analyses of the liquid radioactive waste systems, respectively, will begin in FY 1999. However, assessments of the latter may have to be given higher priority if roadblocks are encountered to the planned reengineering of the PWTP.

Priorities for assessment of TRU wastes will be deferred until the initial DOE decisions on procurement of an ORNL TRU Waste Processing Facility and the opening of the Waste Isolation Pilot Plant are known. Information relevant to both should be available by the end of the 2 nd quarter of FY 1998.

This subtask will receive progressively greater emphasis in FY 1998 and in FY 1999, with most of the focus shifting to support for WM strategic planning in advance of the transition to Landlord funding for newly generated WM activities expected in FY 2000.

\section{Subtask Schedule and Deliverables}

Deliverables:

- Reports provided to the EM-30 Manager by September 1 of each year to support activity data sheet (ADS)/FWP development and other planning activities.

\section{Task 1.2.2 Reengineer Waste Coordination}

Task Description: The objective of this task is to create an expert based waste certification/verification program and organization within WM. Application of the expert based, graded approach includes use of process knowledge for waste characterization to minimize cost to Researchers. Specific subordinate objectives are (1) improve the ORNL Waste Certification process, (2) expand implementation of the Waste Coordination Team, (3) ORNL's No-rad-added Program has been incorporated into the existing Waste Certification Program for implementation to eliminate "policy mixed waste", and (4) strengthen and emphasize the ORNL P2 Program through implementation of specific initiatives. 


\section{Resources}

WMRE Cost to Implement: $\$ 2 \mathrm{M}$

Sources of Funding: ORNL OH - \$375K, EM30 - \$800K, and Generators - \$900K

\section{Subtask 1.2.2.1 Waste Certification Program Implementation}

Subtask Description: This Subtask will (1) improve the ORNL Waste Certification process and (2) develop a consistent, verified, and validated approach to waste characterization. The waste certification program is scheduled to complete pilot testing and become an auditable program in April 1998. The cornerstone of the program is the change from waste item certification to program certification. Adherence to program requirements produces a certified waste. This change requires ongoing surveillance, verifications, and records management, as well as maintenance of certification program documents and resolution of technical issues as they arise. Forms will be upgraded.

\section{Subtask Schedule and Deliverables}

Milestones:

- Implement auditable Waste Certification Program.

Deliverables:

- Interim Assessment 11/17/97.

- Pilot Management Assessment 2/23/98.

- Begin auditable program 4/20/98.

\section{Subtask 1.2.2.2 Generator Interface Program}

Subtask Description: Responsible waste certification requires an understanding of the requirements of the applicable WAC, implementing documents, characterization options, and logistics of getting packages approved and picked up. Generator interface personnel support researchers in completing this job effectively, efficiently, and with a minimum of errors, reducing the risk of improper waste characterization, labeling, packaging, and documenting. This task will reduce researcher time spent on WM activities as determined through customer satisfaction surveys.

\section{Subtask Schedule and Deliverables}

Milestones:

- Begin formalizing Memorandum of Understandings (MOUs) with Research Organizations, January 1998.

Deliverables:

- MOUs with Research Organizations.

\section{Subtask 1.2.2.3 No-rad-added Progran}

Subtask Description: A process is necessary to evaluate hazardous waste to determine whether radioactive contamination has been added as a result of DOE operations. The no-rad-added Program will establish guidelines for making this determination. Once developed, tested, and approved, this program will become part of the waste certification program. Rad protection procedures will be revised as appropriate. 


\section{Subtask Schedule and Deliverables}

Milestones:

- Training to no-rad-added implementing document requirement by April 10, 1998.

Deliverables:

- Revise Hazardous Waste Implementation Procedure by December 19, 1997.

- No-rad-added Implementation Document by March 1998.

- Implement new no-rad-added requirements as part of waste certification program by April 1998.

\section{Subtask 1.2.2.4 P2 Program}

Subtask Description: This Subtask will implement several P2 initiatives, such as implementing a chemical purge team, re-instituting a limited Chemical Stores function with $\mathrm{P} 2$ focus, and reducing the quantity of materials left by retiring and visiting staff. Specific activities to be integrated through this element include:

- Expanding the Waste Coordination Team (Generator Interface Group) to include chemical purge activities that will reduce the current inventory of excess chemicals and equipment at the Lab.

- Establishing and implementing (1) recycle protocols for each recycling effort (e.g. solid waste, laboratory chemicals, electrical wire, used oil, solvents) and (2) material handling protocols which require P2 opportunities be evaluated as a part of planning specific research projects.

- Establishing a virtual Between Use Storage for excess chemicals.

- Establishing a Centralized Chemical Stockroom to better utilize all chemicals, to permanently reduce the Lab's chemical inventory, and to make chemical acquisition and disposal easier and cheaper for the researchers.

- Establishing a link between the Accelerated Vendor Inventory Delivery and Hazardous Material Information System that would alert generators ordering chemicals to the availability of identical chemicals.

- Implementing a departure protocol addressing chemical disposition for personnel that are retiring or otherwise leaving the Lab.

\section{Subtask Schedule and Deliverables}

Milestone:

- Deploy purge team by $01 / 15 / 98$.

Deliverables:

- Issue departure protocol addressing chemical disposition by $12 / 15 / 97$.

- Complete virtual BUS by 12/31/98.

\section{Task 1.2.3 Reengineer SLLW Process}

Task Description: The objective of this task is to reengineer the ORNL SLLW process to mimic that of the commercial nuclear industry. A "green is clean" approach will be developed and implemented by a segregation and contamination control program that is endorsed by ORNL Management. WM through the Waste Coordination Team will take a hands-on approach to rad waste packaging by assisting researchers. In this way, "reducible" waste will be segregated at the source and surveyed for free release. Contaminated waste will be treated for maximum volume reduction and the residual will be disposed with characterization that takes advantage of homogenization. 
NOTE: Reducible waste is waste that is generated within a radiological control area that may be free releasable but can not be shown through routine Radiation Protection (RP) measurements to be completely free of contamination due to material configuration and/or inaccessible surfaces.

\section{Resources}

Total Cost to Implement: $\$ 200 \mathrm{~K}$

Sources of Funding: EM30 savings and existing ongoing SLLW Disposal budget in ADS 3201

\section{Subtask 1.2.3.1 Develop Process Activity Logic Diagrams}

Subtask Description: This Subtask provides for development of SLLW process activity logic diagrams that will be used to guide implementation of process improvements. The process maps will cover the detailed components of SLLW generation and management, emphasizing those aspects that will be opportunities for reengineering and application of $\mathrm{P} 2$.

\section{Subtask Schedule and Deliverables}

Deliverables:

- Detailed Process Maps for SLLW streams by December 30, 1997.

\section{Subtask 1.2.3.2 Planning SLLW Reengineering}

Subtask Description: This Subtask provides for preparation of a proposal that describes ORNL's solid radioactive waste control program (SRWCP). Elements of the proposal may include:

(a) identification of radioactive waste minimization work practices, (b) identification of disposal requirements for both clean and contaminated waste from radiological control areas (RCAs) and items that may be decontaminated, and (c) economic analysis of implementing an SRWCP. The approach will be presented to the LMES SLLW Program Manager to obtain agreement and funding commitment for activities planned to be funded by EM in FY 1998.

The proposal will be presented to management to gain endorsement of the Program. Plant Procedures and Guides to implement requirements of the SRWCP will be revised or developed.

RP specific and Plant awareness training to procedures and guides will be developed and RP and individuals who work in RCAs will be trained.

Subtask Schedule and Deliverables

Milestones:

- Implement SRWCP by May 1, 1998.

\section{Subtask 1.2.3.3 Segregate SLLW from Industrial/Sanitary Waste for Treatment}

Subtask Description: This Subtask provides for implementation of the management-endorsed SRWCP developed in Subtask 1.2.3.2. LMER procurements to (l) ship "reducible" waste to a "free release" vendor and (2) ship SLLW to a vendor for treatment, including contract options for free release, resin stabilization, overpacking, compaction, incineration, and/or metal smelting. The containers needed for implementation will be purchased. Through combined efforts among researchers, WM, and RP SLLW will be segregated from industrial/sanitary waste and "reducible" 
waste will be segregated from SLLW and industrial waste. SLLW will be packaged by the Waste Certification Team (WCT) for researchers to maximize packaging and characterization efficiency.

"Reducible waste" will be shipped off-site to a "free release" vendor where the material will be surveyed for free release potential. Materials meeting their release criteria will be dispositioned as industrial waste and contaminated materials will be returned to ORNL where they will be managed as SLLW.

Milestones:

- Initiate shipments of "reducible waste" to free release vendor by May 15, 1998.

Deliverables:

- Generators segregate sanitary waste and SLLW.

- Reduce SLLW generation by $15-25 \%$.

\section{Subtask 1.2.3.4 Analyze Cost/Benefit to Guide Implementation}

Subtask Description: This Subtask provides for analysis of technical and economic variables to guide implementation of the overall SRWCP. The feasibility to pursue an automated process or facility to check small items for radioactive contamination will be evaluated. Additionally, the report, "Life Cycle Cost Analysis of Volume Reduction Options for Dry Active Low-Level Waste," which was prepared in December 1995 will be validated with actual cost and volume data. Characterization of treatment residuals will be conducted and the data will be used to feed waste stream specific characterization profiles. This Subtask is related to Subtask 1.3.2.3.

\section{Subtask Schedule and Deliverables}

Milestones:

- Issue validated "Life Cycle Cost Analysis of Volume Reduction Options for Dry Active Low-Level Waste - December 1995" by December 1997.

- Complete cost analysis of SLLW incineration by December 1997.

Deliverables:

- Ship suspect SLLW to sorting and free-release contractor.

\section{Subtask 1.2.3.5 Institute Store for Decay Program}

Subtask Description: This Subtask provides for establishing a store for decay program for short half life radioactive isotopes. Operational store for decay programs will be benchmarked to guide development of an ORNL-tailored approach. A storage guide will be prepared, internally reviewed by Environmental Compliance and Radiation Protection staff, and implemented following appropriate training.

Milestones:

- Implement "store for decay" program by January l, 1999. 


\section{Task 1.2.4 Reengineer PWTP}

Task Description: Replace the function of the Process Waste Treatment Plant (PWTP) with more efficient technology and integrate it into the Non-radiological Waste Treatment Plant (NRWTP) operations.

The PWTP produces over 1/3 of ORNL Liquid Low-Level Waste (LLLW) concentrate from regeneration of ion-exchange columns. PWTP LLLW produces sludges which commingle producing an increase in the volume of TRU sludges in the LLLW system. Elimination of this LLLW would reduce future LLLW treatment cost substantially. If the new PWTP unit operation could be physically located at the NRWTP, significant PWTP operational cost could be eliminated.

The Reengineering teams divided this recommendation into two parts:

1. Use technology to eliminate/reduce LLLWW generation from regeneration of current ion exchange columns.

2. Subcontract the financing, design, and construction of the new system, with operations integrated into the NRWTP.

\section{Resources}

ORAL OH Cost to Implement: $\$ 220 \mathrm{~K}$

Source of Funding: Award of Request for Proposal (RFP) funded from cost savings, funding for test and development funded by EM50, WMRE funding for RFP preparation. Subtasks 1.2.4.3, 1.2.4.4 and 1.2.4.5 will be funded by WMRAD Liquid Waste Operations.

\section{Subtask 1.2.4.1 Evaluate Process Improvements}

Subtask Description: Determine if the function of the PWTP can be replaced by using existing equipment at the Non-Radiological Wastewater Treatment Plant (NRWTP). An engineering feasibility study will be completed to establish whether existing columns that are used for removal of organic components from non-radioactive wastewater using granulated activated carbon can be modified to accept zeolites that remove radionuclides from process wastewater. The capital cost of the modification will be determined. A decision will be made in December 1997, based on the results of the feasibility study, whether in-house replacement or subcontract replacement of the PWTP is the most cost-effective approach.

\section{Subtask Schedule and Deliverables}

Milestones:

- Determine whether to modify existing NRWTP equipment or subcontract an improved service to replace the PWTP function by December I, 997.

\section{Subtask 1.2.4.2 Develop Procurement Strategy (if necessary)}

Subtask Description: If modifications to the NRWTP do not fall within capital improvement guidelines for General Plant Project, subcontract performance based service. A make or buy decision has been completed for upgrading the PWTP. Line Item funds have been requested over the past several years with detailed analyses as supporting documentation. Capital funds requests have resulted in a determination that DOE capital funds are unavailable to "make" process improvements as 
required. Therefore, an RFP will be prepared to subcontract services that will replace the operation of the PWTP. Considerations included in the RFP are:

- Subcontract the treatment with mobile process equipment.

- Use union and/or LMER labor to operate and maintain the process.

- Service contract will result in charges based on the volume or units processed that meet performance specifications (a unit price subcontract). Equipment is not leased, it remains the property of the vendor.

- The vendor will train LMER chemical operators to use the vendor's equipment or otherwise negotiate terms and conditions that are acceptable to LMER.

- Payment could be based on the unit cost of waste treated, less labor costs, which would be the responsibility of LMER to pay. Alternately, the vendor could hire LMER labor on a "work for others" subcontract.

- Unit price payments may include incentives to minimize secondary solid and/or liquid waste generated.

The procurement will be accomplished through this subtask. The following steps are planned:

\section{Develop Draft RFP.}

- Determine method for proving process (e.g., performance contract where performance risk is borne by the subcontractor, in-house proof of process, or vendor testing with technical oversight by LMER)

- Determine relationship between capital equipment criteria and performance contract.

- Conduct cost/benefit analysis including "should cost" and "actual cost" as well as life cycle cost analysis of vendor's proposal.

- Allow for potential subcontractors to propose options such as operation of the complete Non-Rad Treatment Plant rather than a single unit operations.

Issue Commerce Business Daily (CBD) Expression of Interest

Review responds to CBD

Refine statement of work and specification as documented in the final RFP

Issue RFP

Prebid Conference/Tour

Response to RFP (bids due)

Evaluate bids

Questions and answers to responses

Interrogatories

- If one bidder conduct audit, if more than one bidder charter an evaluation team,

- If one or more of the bidding companies are foreign-owned, conduct additional evaluations

Best and Finals Due

Complete Evaluation and Team Report

Negotiate contract

Perform Audits

- Audit/Foreign Ownership/other procurement issues/negotiations

Obtain Approvals

Contract award

Award Notice

Mobilization and Start Readiness Review 


\section{Subtask Schedule and Deliverables}

Deliverables:

- Issue Performance-Based Request for Proposal (RFP) with use of LMER union labor as requirement by May 1998.

- Award Services Contract by November 1998.

\section{Subtask 1.2.4.3 Implement Technology}

The improved process will be implemented under this subtask. WMRAD will conduct Operational Readiness Reviews, jointly test and startup the process. As the technology and terms and conditions of the procurement are understood, operational readiness planning will be initiated. Smooth transition to operations including technical, labor and regulatory aspects will result from early planning and preparation.

\section{Subtask Schedule and Deliverables}

Deliverables:

- Conduct Operational Readiness Reviews.

\section{Subtask 1.2.4.4 Update Records to Reflect Improvements}

Drawings, records, procedures and permits will be updated to reflect modification of the Non-Rad Wastewater Treatment Plant and the safe standby or shutdown of the PWTP. Surveillance and maintenance will be initiated and implemented as planned. Operations will ensure that process changes are well analyzed and do not adversely affect other operations, approved, baselined and reflected in documentation.

\section{Subtask Schedule and Deliverables}

Deliverables:

- Updated drawings, records, procedures and permits by May 1999.

\section{Subtask 1.2.4.5 Shut Down Process Waste Treatment Plant}

Shut down, decommission and decontaminate PWTP or place the facility under surveillance and maintenance as determined during operational readiness planning. WMRAD will be responsible for this task and will use savings from improved operations to fund planning for shutdown.

\section{Subtask Schedule and Deliverables}

Deliverables:

- Processes shutdown by May 1999.

\section{Task 1.2.5 Requirements Evaluation and Elimination}

Select an on-site transportation safety plan which ensures that the health and safety of workers, the public and the environment are protected. 


\section{Resources}

ORNL OH Cost to Implement: $\$ 5 \mathrm{~K}$

Sources of Funding: WMRAD/WMRE

\section{Subtask 1.2.5.1 Eliminate On-site Department of Transportation (DOT) Equivalency}

Subtask Description: Background. Based on a Tiger Team visit in 1991, one of the findings related to the then draft DOE Order 5480.3. The finding generally stated that ORNL needed to have an onsite transportation safety plan. To close this finding, ORNL established an on-site transportation manual. Although this manual is written based on DOT requirements, it also is written to allow operation managers to use discretion and judgement in applying the manual.

The question then becomes: "Are the DOT standards (since they were written to regulate off-site, across-country transportation that will come into contact with the public) too strict to be used for onsite transportation?" and "Could we do the same job at a lower cost if we replaced these standards and only enforced other "on-site, worker-related" standards such as Occupational Safety and Health Act of 1970 (OSHA) and/or RadCon?" The answer to these questions is, "Regardless of the standards cited, the present manual is protective of transportation safety on-site." The DOT standards may even be superior for ORNL purposes because they are simple to use and easy to apply. Regardless of the selected standard, the existing on-site transportation manual ensures worker safety because it provides a systematic and repeatable safety system for transportation." Further, the manual is continuously improved.

Defining "On-Site." Another issue related to this subject is how one defines "on-site." The on-site issue is being addressed by evaluating the locations of "gates and guards" on "interior and plant roads." Related to this a DOE Program Manager asked DOT staff general questions related to how one should define "on-site." These general questions were answered, "within the gates of a facility/plant/etc." Therefore, guard posts were established to maximize the boundaries of DOE sites. Later, more specific questions were asked of DOT about the Oak Ridge Site. The response to the more specific questions changed the interpretation of "on-site" for DOT Hazardous Materials Regulations. The requirement for guards and locked gates was eliminated because public access to facilities is controlled. This modification of requirements resulted in a determination that the current number of guard posts can be reduced. The saving related to a reduction in the number of guards and gates is expected to be $\$ 300,000$ per year in security alone.

Required Actions: Resource Conservation and Recovery Act (RCRA) permits include the present configuration of gates and will be modified to reflect guidance from DOT: ORNL will continue to follow DOT on-site requirements for movement of hazardous materials and waste. WM must document a position on whether to comply with OSHA for on-site transportation or request an exemption per the manual. Modification of current operating procedures is not planned.

Environmental Compliance staff are scheduled to request a revision to the RCRA permit by November 1997.

${ }^{a}$ Letter, E. H. Bonekemper, III, US-DOT, Research and Special Program Administration, to R. E. Bell, Lockheed Martin Energy Systems, Office of General Counsel, August 19, 1997. 


\section{Subtask Schedule and Deliverables}

Deliverables:

- DOT review and evaluation - Complete.

- Re-negotiate/modify on-site waste transportation permits by December 1997.

\section{Subtask 1.2.5.2 Negotiate "Above-and-Beyond" Requirements from RCRA Permits}

Subtask Description: In the past, DOE sites have not only met but exceeded requirements. DOE sought a "above-and-beyond" approach to meeting requirements such as those associated with RCRA. However, with the current reductions in funding, the new philosophy is to work smarter and more efficiently. WMRAD developed and implemented a Regulatory Requirement Units (RU) Database that has been used to successfully track 1,500 permit requirements. This system has resulted in eliminating non-compliance with RCRA permits. However, WM practices may exceed RCRA requirements and these "heroic measures" may have been documented in permit requirements.

A plan to reduce the cost of implementing RCRA and tracking permit requirements has been developed and is being implemented: ORNL staff are working with the state permitting agencies to align reporting and tracking requirements with the type of work being done. In some cases, negotiation with regulators could result in reducing or eliminating requirements. However, regulator, DOE, and management confidence in the ability of reduced requirements to mitigate risk may have been undermined by recent accidents. The ability to accept risk and/or liability must be weighed against rewards obtained for completing work activities more cost-effectively. Therefore, ORNL's business position with regard to accepting risk must be weighed against potential cost savings resulting from modified work practices.

Staff accomplishing this task will review the RU Database against criteria such as the regulatory basis for the RU and whether re-negotiation of the RU makes sense from a business perspective. Review of the database will guide subsequent review of operations to determine if-streamlining work practices is practical and cost-effective. A plan will be developed to re-negotiate permit requirements to reduce or eliminate RUs that are not consistent with regulatory requirements and that do not clearly protect human health, the environment, or worker safety.

\section{Subtask Schedule and Deliverables}

Milestones:

- RU Review Team Identification.

- Submit "N\&S" process results for approval.

Deliverables:

- RU Team Charter.

- RU Database evaluation report.

- Complete plan to implement RCRA permit modifications by July 1998.

\section{Subtask 1.2.5.3 Apply N\&S Process}

Subtask Description: The goal of the N\&S is to save time and money by eliminating unnecessary requirements that tend to slow down operations. To date a core team was formed that met for several months and reviewed about $85 \%$ of the ORNL facilities and developed an ORNL-wide Preliminary Hazards List. They complied, analyzed, and evaluated this list to investigate how current laws, regulations, and standards satisfy and mitigate these hazards. 
Presently the remaining $15 \%$ of the facilities were categorized as Nuclear Facilities or Accelerators and included most of WMRAD, REDC, and some facilities in other divisions. Thirteen WMRAD facilities that were categorized as hazardous have already been reviewed during earlier efforts and documentation is in the signature and approval cycle. WMRAD has 123 more facilities to be reviewed. The 11 member WMRAD team meets once a week for about a two-hour meeting. All members' time charges are charged to their own departments.

Facility Managers are responsible for evaluating their facilities against the preliminary hazards list. The Identification Team reviews the Preliminary Hazards List and develops listing of standards that satisfy requirements, ensures that standards are added when needed, and identifies governing or different hazards. The Team will document its findings review and resolve comments, develop alternatives and changes that will satisfy the goals of the N\&S process. An analysis of the cost and benefits associated with proposed changes will be conducted and the proposed changes will be approved by Laboratory and/or EM\&EF management as required. Changes will be implemented including modification of records, documents, and procedures to reflect changes. WMRE staff will track the results of $N \& S$ process implementation.

\section{Subtask Schedule and Deliverables}

Milestones:

- Establish WMRAD Identification Team.

Deliverables:

- Listing of standards by October 1997.

- Obtain approval of N\&S changes by December 1997.

- Change records, documents, and procedures to reflect changes by September 1998.

Subtask 1.2.5.4 Implement Graded Approach to WM Conduct of Operations (COO) Background. The graded approach to WM COO is a subset of the N\&S effort being performed at ORNL. COOs standards were designed to make radiological facilities safer to operate by providing a detailed outline and system of checks for facility managers to use in designing operations. However, since this system was designed for high technological and risk areas requiring high level of management, lower risk areas or less complicated work environments (e.g., non-nuclear facilities) can be unnecessarily burdened by the same standards. Providing less rigorous interpretation of these standards for less demanding environments (graded approach) is the goal of this subtask.

DOE-WM focused on COO during the first evaluation of N\&S standards for ORNL WM facilities. DOE Héadquarters approved a list of ORNL WM General or Industrial facilities that would not be subjected to COO. However, DOE Site Facility Representatives supported full COO for ORNL WM facilities, especially nuclear facilities. The ORNL N\&S team is currently reviewing WM radioactive facilities and is scheduled to finish in November (see Subtask 1.2.5.3). LMES-EM will direct the ORNL COO level of effort until April 1998. Current efforts are increasing because of recent problems and accidents and additional requirements are continuing to be identified.

Management has focused on $\mathrm{COO}$ and the N\&S process. These programs are mature and offer little opportunity for reengineering. However, training requirements for certain WMRAD facilities could be reduced. For example, $\mathrm{COO}$ requires one-on-one training for all operators. The existing procedure requires the foreman to conduct this training. While this level of supervision during training is appropriate for nuclear facilities, this requirement could be reduced for non-nuclear WMRAD facilities. Reducing training requirements is one aspect of N\&S implementation that is specific to COO. An estimated $2-3 \%$ of chemical operators' time could be redirected if a modified training 
approach were adopted within WMRAD. However, before such an effort was undertaken, additional activities must be identified. WMRE staff will initially identify opportunities such as work for the M\&I contractor or a private waste treatment contractor and work with LGWO staff to implement costeffectiveness gains as appropriate.

\section{Subtask Schedules and Deliverables:}

Milestones:

- Identify opportunities to implement a graded approach to the WM Conduct of Operations process.

\section{Task 1.2.6 Ship Mixed Waste to East Tenıessee Technology Park (ETTP)}

Task Description. This in an ongoing project which depends on funding for characterization and shipment. WMRAD staff are actively pursuing shipment of mixed waste to ETTP.

Administrative (e.g., documentation, approvals) and funding issues are being resolved by DOE-OR Operations, ETTP, and WMRAD staff. WMRE supports this important initiative. No ORNL overhead nor waste generator involvement is required to resolve issues (see Appendix B. WBS 1.2.6).

\section{Subtask 1.2.6.1 Remove Barriers}

Subtask Description. Safety documentation at ETTP must be reviewed and modified, as needed. Funding for characterization is needed.

\section{Subtask 1.2.6.2 Accelerate Shipments}

Subtask Description. WMRAD and DOE-OR Operations are accelerating shipments.

\section{Task 1.2.7 Future Endeavors}

Task Description. Additional actions were identified by the WMRE Core Team and process teams, but were given lower priority for implementation. These actions included expanded use of the Y-12 landfill for ORNL wastes and use of Buildings 3517 and 3525 for waste treatment. After the WMRE initial highpay back tasks are clearly proceeding as planned, these suggested actions may be reevaluated. In addition, the ongoing WMRE tasks may identify future actions that would further reduce costs. These actions, which may be identified in the future, will be placed in this WBS so the appropriate course of action can be determined.

Subtask 1.2.7.1 Use Bldg. 3517 and 352.5 for Waste Treatment

Subtask 1.2.7.2 Evaluate Expanded use of Y-12 Landfill

\section{WBS 1.3 ADVANCED INFORMATION MANAGEMENT SYSTEMS}

\section{Task 1.3.1 Upgrade current waste tracking system}

Task Description: Upgrade the current waste tracking system (WTS) to provide DOE with the required data output through a WITS interface capability. Propose to DOE-EM a cost-effective alternative to WITS. Continue adjustments to WTS to accomplish the DOE-OR Operations objective of reporting to a centralized database. 


\section{Resources}

ORNL OH Cost to Implement: $\$ 50,000$

Sources of Funding: Unfunded

\section{Task 1.3.2 Create a "Seamless" WM Information Management System}

Task Description: Core team recommendation number 5 , to create a single, expert-based ORNL waste characterization/verification/certification program and organization, relies on the deployment of systems, technology, and experts for the characterization of waste. This will enable other core team recommendations to be realized, for example: (1) improved tools and forms for use by waste generators and generator interface staff; (2) an engineered approach to no-rad-added determinations; (3) a WM strategy for eliminating or reducing, aggregating, treating, and matching waste streams to an endpoint, (4) an approach to characterization that will demonstrate that DQOs are satisfied; (5) provide vital information into the advanced information management system, including auditable isotope assay data, associated uncertainties, and process variability; and (6) to team with generator organizations, the existing Generator Interface Group, WM Solid Waste Operations Group, and the WCT.

This task will restructure the existing waste information support system to provide a more seamless approach that encompasses the "cradle-to-grave" WM process. The reengineered system will be fully integrated throughout the entire WM process, providing "real time" inventory management, compliance tracking, shipment planning, and requirement reporting. The system will link with the recently installed infrastructure components in a seamless fashion to eliminate the need for numerous special purpose subsystems and their associated duplication of effort in data entry and analysis.

This seamless WM information system will link characterization, verification, DQOs, transportation, and disposal endpoints. Implementation of this vision requires a clear understanding of how current activities are conducted and how they should be changed to achieve cost-effectiveness. This task will develop a plan, obtain review and approval of concepts, and secure approval for the selected approach. The goal is to reengineering existing generator and WMRAD activities so cost-effectiveness gains can be redirected to a more efficient process that will result in ORNL waste disposal and an increase in ORNL WM capacity at low unit cost.

\section{Resources}

ORNL OH Cost to Implement: $\$ 140 \mathrm{~K}$

Sources of Funding: WMRE, WMRAD, Unfunded

\section{Subtask 1.3.2.1 Develop DQOs Covering Characterization and Waste Form}

Subtask Description: DQOs covering characterization and waste form need to be developed and agreed upon for each disposal endpoint [e.g., identified in Subteam Recommendations DE-6(a) and $\mathrm{DE}-7]$ in order to guide those analyzing or conducting the intermediate steps in the process (characterization, up-front waste reduction, treatment and volume reduction, certification, and packaging) (i.e., initiation of endpoint-focused cradle-to-grave WM; Subteam Recommendation $\mathrm{DE}-3$ ). Following development and internal acceptance, support will be provided to the ORNL advocate for disposal endpoints to assist her/him in obtaining acceptance by the disposal site. 


\section{Subtask Schedule and Deliverables}

Milestones:

- Complete internal DQO development for projected SLLW and mixed wastes disposal sites (NTS, Hanford, and Envirocare) by January $31,1998$.

- Schedule DQO development for TRU wastes based on feedback from DOE decision-making on the TRU Waste Processing Facility and the WIPP; tentatively to be completed by December 31, 1998.

Deliverable:

- Obtain internal acceptance for and provide report documenting DQOs for SLLW and mixed wastes by March 31, 1998.

- Obtain internal acceptance for and provide report documenting DQOs for TRU wastes; tentatively by March 3 1, 1999.

\section{Subtask 1.3.2.2 Deploy Technology to the Waste Certification Process}

Subtask Description: Several improvements to WMRAD can be realized by the deployment of information management technology. A position will be developed that integrates characterization and verification technology with disposal endpoint WAC. A streamlined characterization/verification system will be proposed under this subtask. The proposal will include alternative methods for conducting WM verification that may be more cost-effective. This expert-based system will rely on personnel as well as tools.

This process will be facilitated by using commercially available off-the-shelf hardware and software. The existing waste tracking systems will be reengineered into an advanced WM information system with the following capabilities:

- The system will be designed to capture and distribute waste information.

- The system will be able to track and trend information.

- The system will be capable of linking waste from the generator to the final disposal endpoint.

- The system will be capable of tracking and trending waste information facility by facility.

The system will include smart processing for consistent decision analysis (including feedback/branching based on input data), and validate user input entries. The Subtask includes installing and testing procured software and/or hardware, creating Test date, execute system validating user input entries.

\section{Subtask Schedule and Deliverables}

Deliverable:

- Complete position paper on improved characterization, verification, and certification through DQO implementation by January 1998.

\section{Subtask 1.3.2.3 Provide Information Management Tools and Forms}

Subtask Description: A diagnostic review of the records and reports generated to document the WM process indicates that improving the current technology status should rapidly result in efficiency gains and/or cost savings.

Provide the following information management tools and forms:

- Optimal Generator Entry System (GES) 
- Track 90-day accumulation areas w/GES

- Barcoding

- New Reporting Tool

- GES Template

- Electronic Inspection Record Keeping

- Electronic Process Knowledge Form

Subtask Schedule and Deliverables

Deliverables:

- Improved information management tools and forms by September 1998. 
APPENDIX C

COST BY WORK BREAKDOWN STRUCTURE 
Waste Management Reengineering Implementation Cost by Work Breakdown Structure

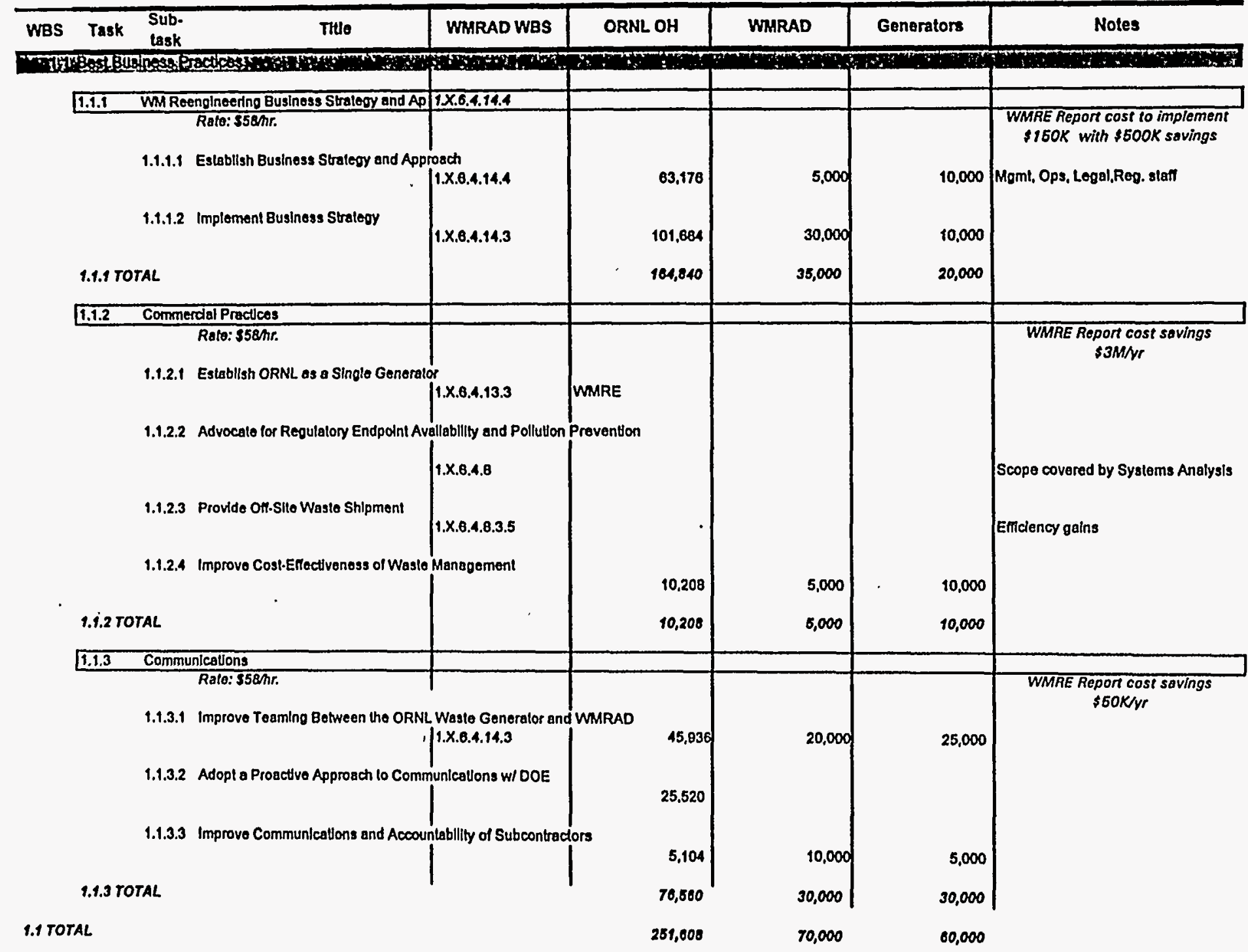


Waste Management Reengineering Implementation Cost by Work Breakdown Structure

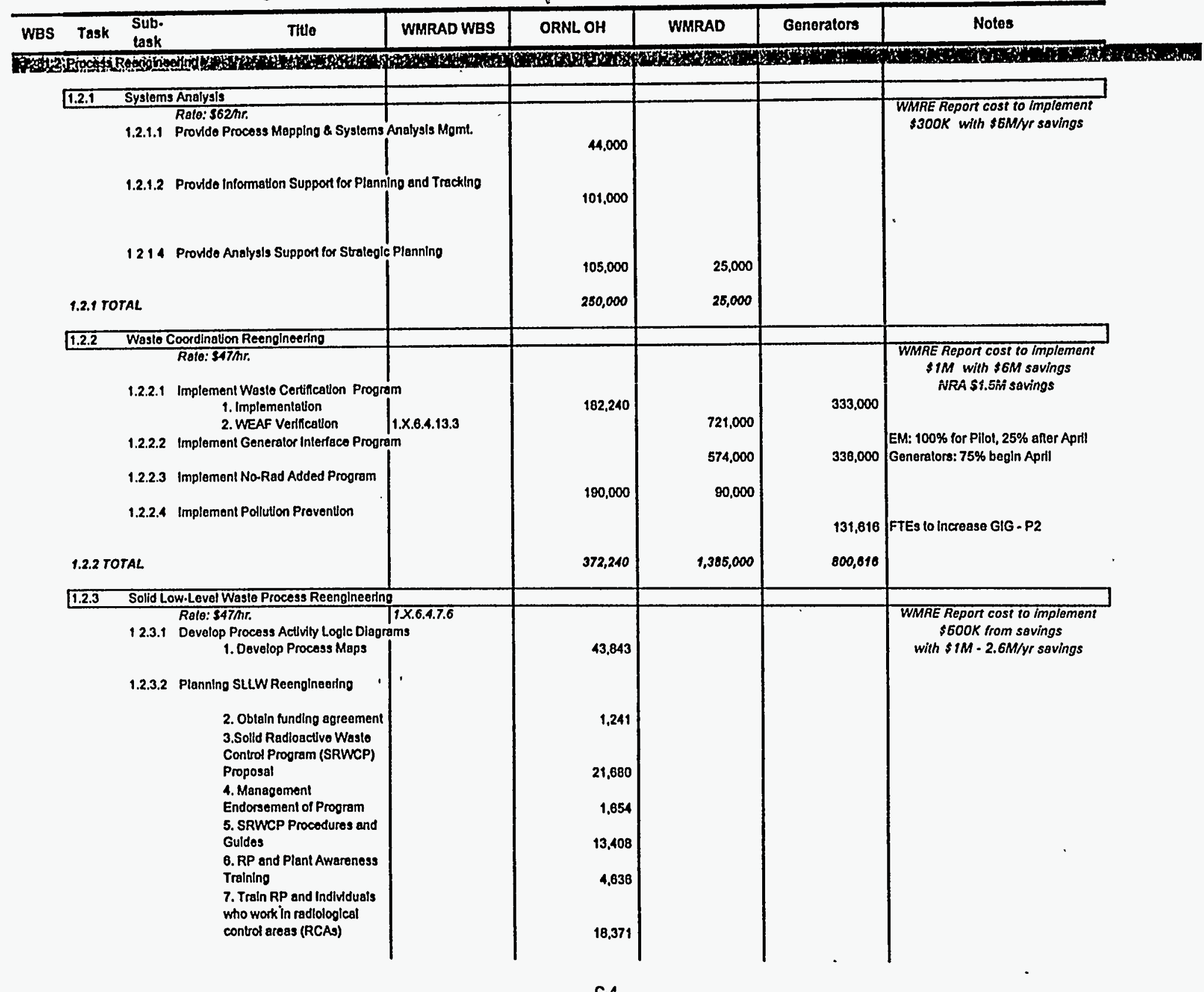


Waste Management Reengineering Implementation Cost by Work Breakdown Structure

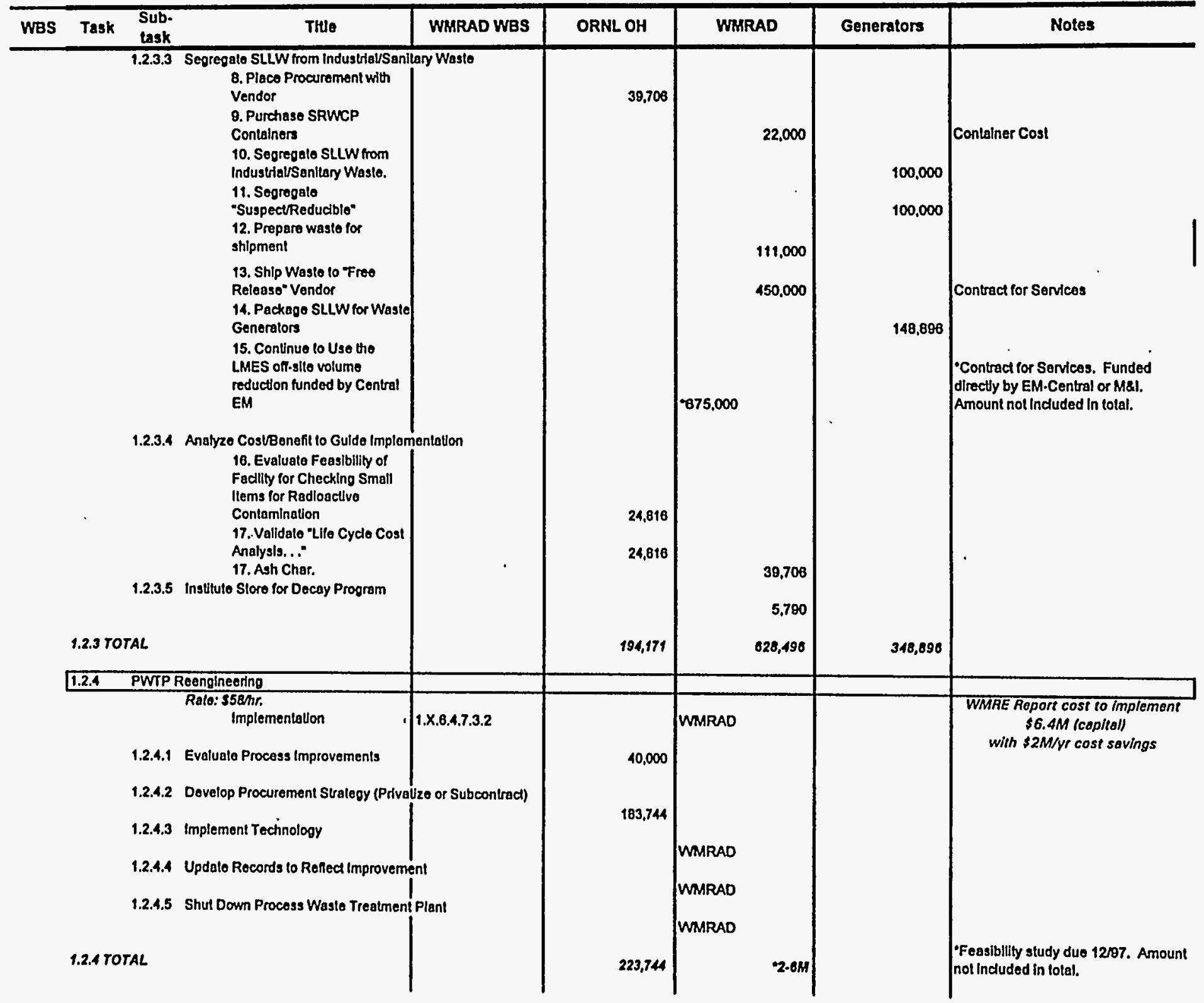


Waste Management Reengineering Implemientation Cost by Work Breakdown Structure

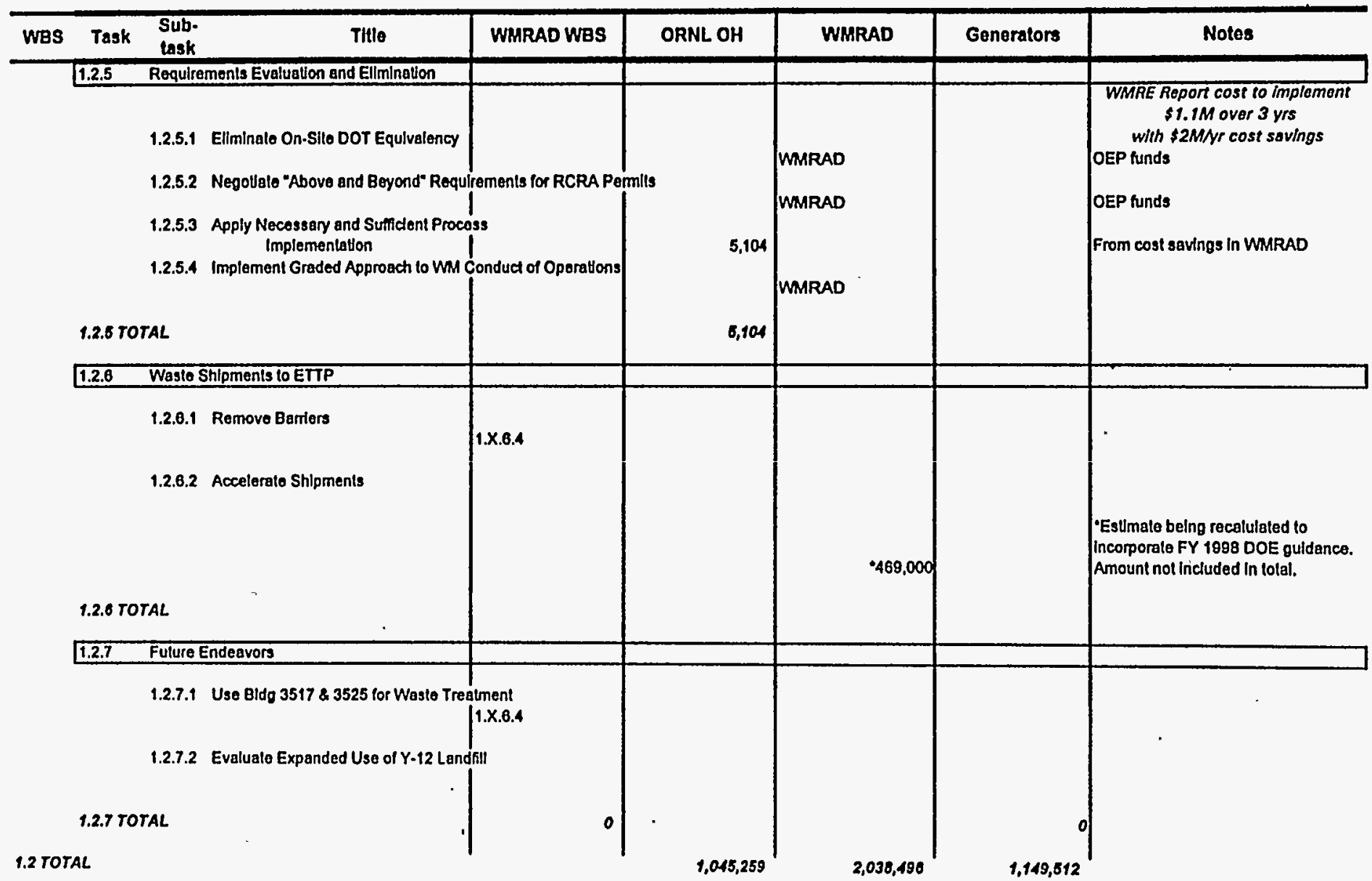


Waste Management ReengIneering Implementation Cost by Work Breakdown Structure

\begin{tabular}{|c|c|c|c|c|c|c|c|c|}
\hline WBS & Task & $\begin{array}{l}\text { Sub- } \\
\text { task }\end{array}$ & Title & WMRAD WBS & ORNL OH & WMRAD & Generators & Notes \\
\hline \multicolumn{9}{|c|}{ We } \\
\hline \multicolumn{2}{|c|}{1.3 .1} & \multicolumn{2}{|c|}{ Upgrado of Current Waslo Tracking System } & & & $\begin{array}{l}50,000 \\
50,000\end{array}$ & & $\begin{array}{c}\text { WMRE Report cost lo implement } \\
\$ 150 \mathrm{~K} \text { w/\$800K cost sovings } \\
\text { in FY } 1998\end{array}$ \\
\hline & 1.3 .2 & $\begin{array}{l}\text { Croation } \\
1.3 .2 .1 \\
\text { 1.3.2.2. }\end{array}$ & 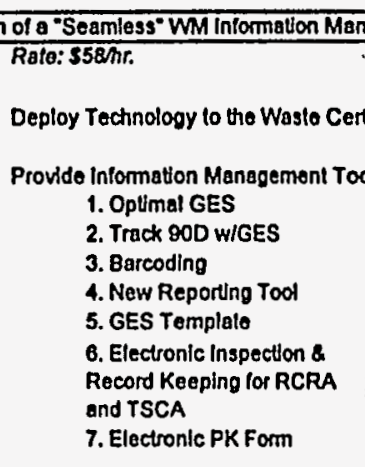 & $\begin{array}{l}\text { incation Process } \\
\text { I.X.8.4.13.4 }\end{array}$ & $\begin{array}{r}60,040 \\
1,531 \\
3,002 \\
32,686 \\
5,104 \\
\\
34,707 \\
5,104 \\
\end{array}$ & $\begin{array}{r}511 \\
0 \\
18,375\end{array} \mid \begin{array}{r}3.062 \\
\\
14,282 \\
3.082 \\
\end{array}$ & 40,000 & $\begin{array}{l}\text { WWRE Report cost ro implement } \\
\text { \$140K W/s } 1.4 M / Y r \text { cost sovings }\end{array}$ \\
\hline & \multicolumn{3}{|c|}{ 1.3.2 TOTAL } & & 148,214 & 39,302 & 40,000 & \\
\hline $1.3 \mathrm{ro}$ & & & & & 148,214 & 89,302 & 10,000 & \\
\hline
\end{tabular}

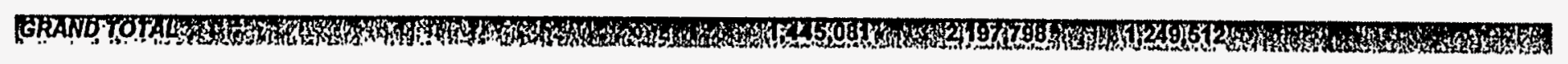


APPENDIX D

WMRE SCHEDULE 


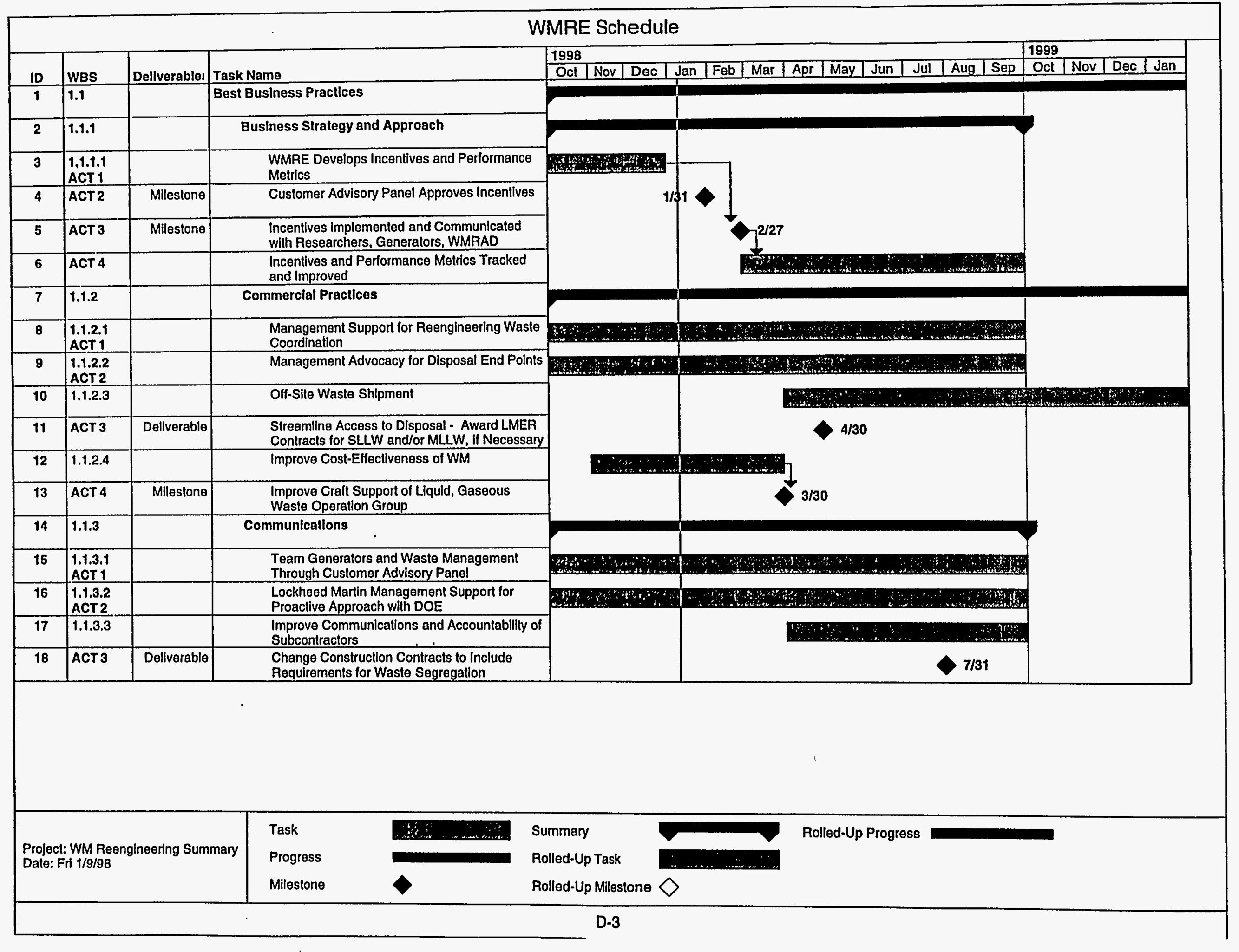




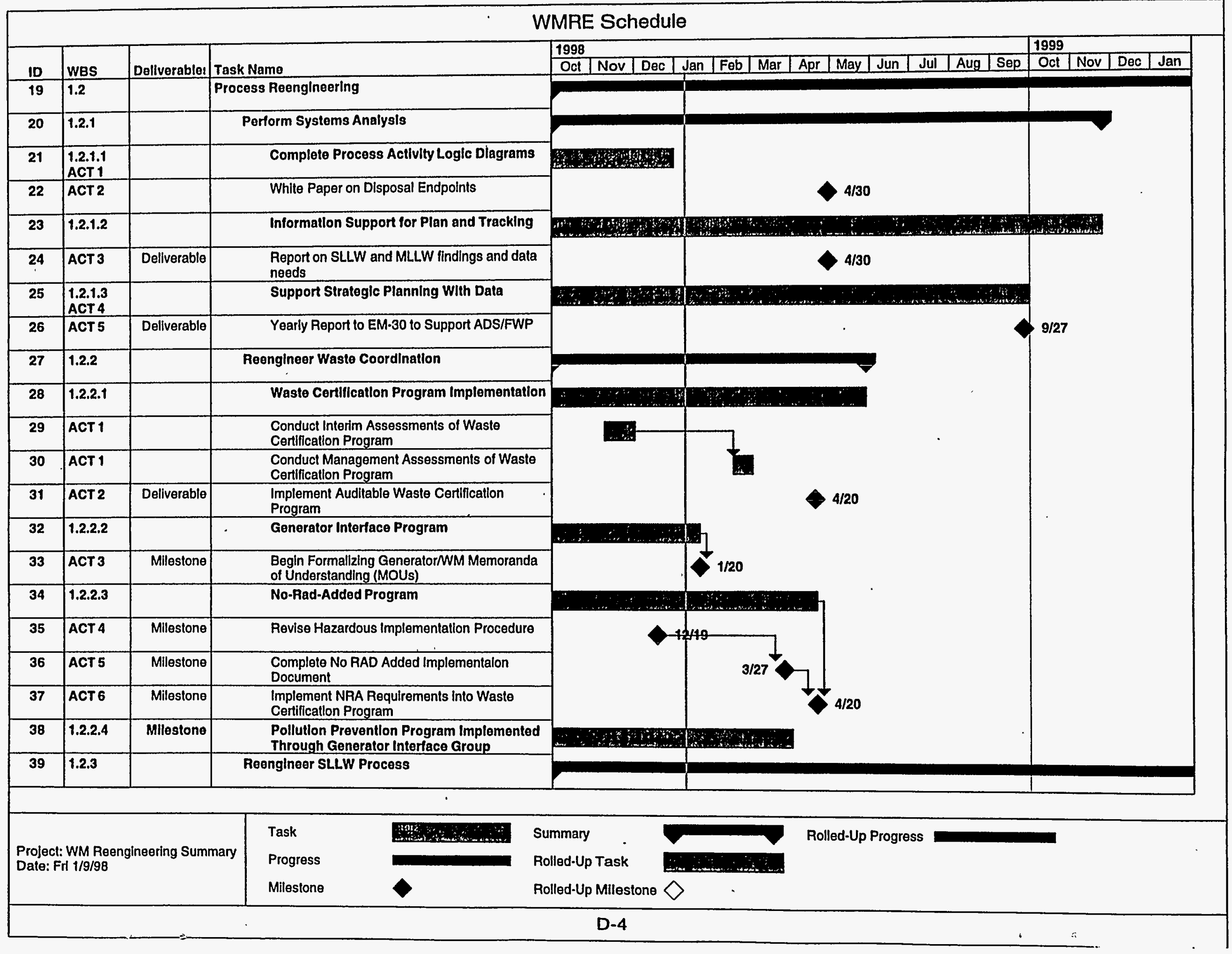




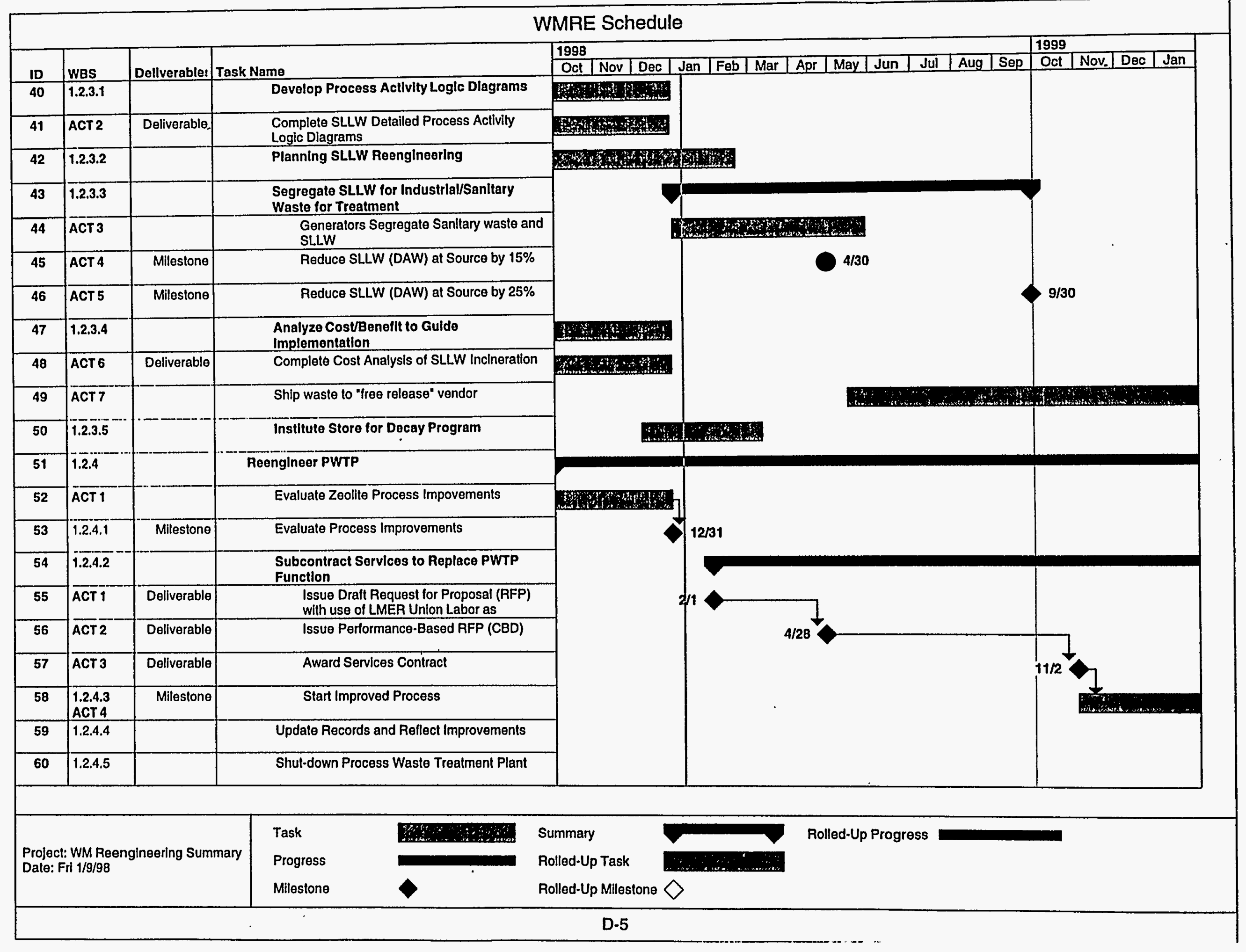




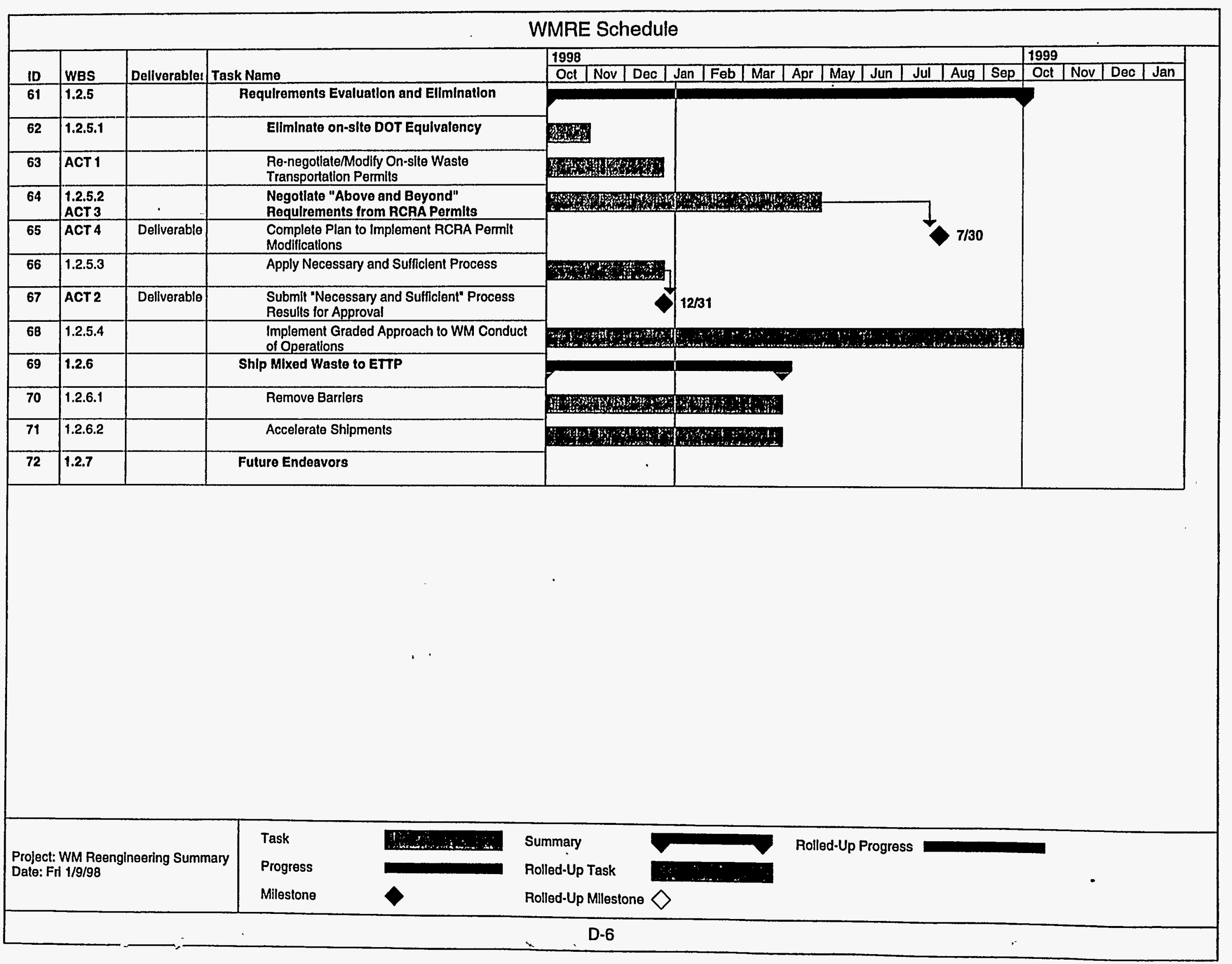




\begin{tabular}{|c|c|c|c|c|c|c|}
\hline \multicolumn{7}{|c|}{ WMRE Schedule } \\
\hline & & & & 1998 & का & 1999 \\
\hline ID & WBS & Dellverable! & Task Name & 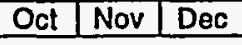 & \begin{tabular}{l|l|l|l|l|l|l|l|l|} 
Jan & Feb & Mar & Apr & May & Jun & Jul & Aug \\
\end{tabular} & \begin{tabular}{l|l|l|l|l|l|} 
Oct & Nov & Dec & Jan \\
\end{tabular} \\
\hline 75 & 1.3 & & Advanced Information System & & & \\
\hline 76 & $\mathbf{1 . 3 . 1}$ & & Upgrade Waste Tracklng System & & & \\
\hline 77 & 1.3 .2 & & Create a Seamless Waste IMS & & & \\
\hline 78 & 1.3.2.1 & & Provlde Informatlon Management Tools & & & \\
\hline 79 & ACT 3 & Dellverable & Improve Informalion Management Tools & & 3/30 & \\
\hline 80 & 1.3.2.2 & & DaOs covering Charaterization \& Waste Form & & & \\
\hline 81 & ACT 1 & Milestone & $\begin{array}{l}\text { Develop Dala Quallity Objectives (DQO's) } \\
\text { Covering SLLW and MLLW Characterizalion }\end{array}$ & $i$ & & \\
\hline 82 & 1.3.2.3 & & $\begin{array}{l}\text { Deploy Technology to the Waste Certification } \\
\text { Process }\end{array}$ & & & \\
\hline 83 & ACT 2 & Deliverable & $\begin{array}{l}\text { Complete Posittion Paper on Improved } \\
\text { Characterization, Verification, and Certification }\end{array}$ & & & \\
\hline
\end{tabular}

\begin{tabular}{|l|lll|}
\hline $\begin{array}{l}\text { Project: WM Reengineering Summary } \\
\text { Date: Fri 1/9/98 }\end{array}$ & $\begin{array}{l}\text { Task } \\
\text { Progress } \\
\text { Milestone }\end{array}$ & $\begin{array}{l}\text { Summary } \\
\text { Rolled-Up Task } \\
\text { Rolled-Up Milestone }\end{array}$ \\
\hline & 0.7 \\
\hline
\end{tabular}


ORNL/TM-13520

\section{INTERNAL DISTRIBUTION}

1. R. R. Arp

2. J. B. Ball

3. K. A. Balo

4-23. J. B. Beiry (20)

24. B. A. Berven

25. W. J. Bohannon

26. W. D. Brickeen

27. J. B. Cannon

28. J. A. Chapman

29. D. F. Craig

30. A. G. Croff

31. J. Cunningham

32. D. L. Daugherty

33. R. A. Dean

34. J. L. Dippo

35. D. D. Drake

36. L. D. Duncan

37. K. G. Edgemon, Jr.

38. E. C. Fox

39. R. K. Genung

40. R. G. Gilliland

41. H. A. Glovier

42. K. W. Haff

43. J. L. Hammontree

44. J. N. Herndon

45. J. R. Hightower

46. S. G. Hildebrand

47. P.S. Kirkham

48. M. W. Kohring

49. E. H. Krieg, Jr.

50. J. J. Maddox
51. R. C. Mann

52. R. C. Mason

53. B. C. McClelland

54. D. W. McDonald

55 B. M. McNeely

56. L. E. McNeese

57. L. J. Mezga

58. S. R. Michaud

59. W. H. Miller

60. T. E. Myrick

61. R. C. Orin

62. J. R. Parrott

63. D. C. Parzyck

64. M. L. Poutsma

65. J. B. Roberto

66. L. C. Roddye

67. T. F. Scanlan

68. R. B. Shelton

69. C. S. Sims

70. T. L. Sizemore

71. J. O. Stiegler

72. L. E. Stratton

73. J. H. Swanks

74. K. B. Thomas

75. J. R. Trabalka

76. M. W. Tull

77. R. J. Verastegui

78. Laboratory Records - RC

79-80. Laboratory Records (2) - for transmittal to OSTI

\section{EXTERNAL DISTRIBUTION}

1. S. M. Blacker, MACTEC, Inc.

2. D. T. Duncan, PrSM, Corp.

3. S. M. Gibson, DOE-ORO

4. M. J. Kass, DOE-ORO

5. F. J. Pumillo, Lockheed Martin Management and Data Systems 